\title{
ATIVIDADE INSETICIDA E MODO DE AÇÃO DE EXTRATOS DE MELIÁCEAS SOBRE Bemisia tabaci (GENN., 1889) BIÓTIPO B
}

\author{
ANTONIO PANCRÁCIO DE SOUZA
}

Tese apresentada à Escola Superior de Agricultura "Luiz de Queiroz", Universidade de São Paulo, para obtenção do título de Doutor em Ciências, Área de Concentração: Entomologia.

\author{
PIR A C I C A B A \\ Estado de São Paulo - Brasil \\ Janeiro - 2004
}




\title{
ATIVIDADE INSETICIDA E MODO DE AÇÃO DE EXTRATOS DE MELIÁCEAS SOBRE Bemisia tabaci (GENN., 1889) BIÓTIPO B
}

\author{
ANTONIO PANCRÁCIO DE SOUZA \\ Biólogo
}

Orientador: Prof. Dr. JOSÉ DJAIR VENDRAMIM

Tese apresentada à Escola Superior de Agricultura "Luiz de Queiroz", Universidade de São Paulo, para obtenção do título de Doutor em ciências, Área de Concentração: Entomologia.

P I R A C I C A B A

Estado de São Paulo - Brasil

Janeiro - 2004 
Dados Internacionais de Catalogação na Publicação (CIP)
DIVISÃO DE BIBLIOTECA E DOCUMENTAÇÃO - ESALQ/USP

Souza, Antonio Pancrácio de

Atividade inseticida e modo de ação de extratos de meliáceas sobre Bemisia

tabaci (Genn., 1889) biótipo B / Antonio Pancrácio de Souza. - - Piracicaba, 2004.

$101 \mathrm{p}$.

Tese (doutorado) - Escola Superior de Agricultura Luiz de Queiroz, 2004.

Bibliografia.

1. Entomologia agrícola 2. Mosca-branca 3. Planta produtora de pesticida 4. Praga de planta 5. Rutales I. Título

CDD 632.951

"Permitida a cópia total ou parcial deste documento, desde que citada a fonte - $O$ autor" 


\section{AGRADEÇO}

A Deus, pela oportunidade de viver momentos tão especiais.

\section{OFEREÇO}

aos meus pais, João Pancrácio de Souza e Elza de Souza,

e aos meus irmãos Pancrácio (In memorian), Oribes, Gilberto e Magno. 


\section{DEDICO}

À Luciane Julião dos Santos, minha companheira de todos os momentos, 


\section{AGRADECIMENTOS}

Ao Prof. Dr. José Djair Vendramim, pela excelente orientação, amizade e equilíbrio, características que me trouxeram refrigério para seguir em frente.

Ao Prof. Dr. Celso Omoto, pela revisão do "Summary".

Aos colegas Fábio, Enrique, Paulo, Edilene, Rita, Uemersom, Márcio, Cia e Bruno, pela amizade e boa convivência no laboratório.

Ao Conselho Nacional de Desenvolvimento Científico e Tecnológico (CNPq), pela concessão de bolsa de estudos.

À Fundação de Amparo à Pesquisa do Estado de São Paulo (FAPESP), pelo apoio financeiro para execução do projeto.

Aos professores do Departamento de Entomologia, Fitopatologia e Zoologia Agrícola, pelo incentivo, dedicação no ensino e exemplo de 
ética profissional associados com a amizade e respeito aos alunos.

Aos funcionários do Setor de Entomologia, por toda espécie de apoio sempre bem-vindo.

Ao Dr. André Luiz Lourenção, pelo fornecimento de insetos para início da criação de mosca-branca.

E a todos aqueles que participaram em alguma etapa desse processo, meus sinceros agradecimentos. 


\section{SUMÁRIO}

Página

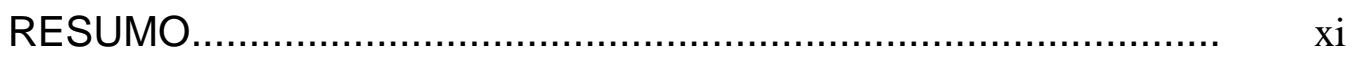

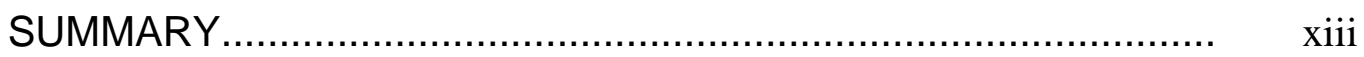

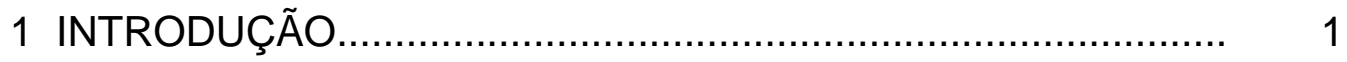

2 REVISÃO DE LITERATURA...............................................

2.1 Mosca-branca Bemisia tabaci .............................................. 3

2.1.1 Aspectos taxonômicos, distribuição geográfica e plantas

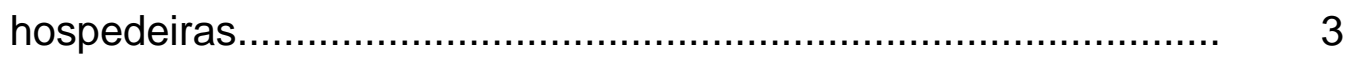

2.1.2 Aspectos morfológicos e ecológicos............................. 8

2.1.3 Aspectos biológicos de B. tabaci biótipo B.................... 12

2.2 Extratos botânicos.......................................................... 15

2.2.1 Considerações gerais......................................................... 15

2.2.2 Trichilia pallida ..............................................................................

2.2.3 Efeito de derivados de nim sobre insetos sugadores.............. 18

2.2.4 Efeito de extratos botânicos sobre Bemisia spp..................... 22

2.2.5 Metodologia de extração de compostos inseticidas............... $\quad 29$ 


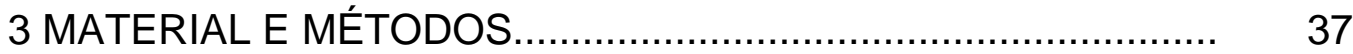

3.1 Obtenção e criação dos insetos.................................. 37

3.2 Obtenção do material vegetal e dos extratos...................... 38

3.3 Determinação das concentrações adequadas dos extratos a serem utilizadas nos experimentos.................................. 39

3.3.1 Ação translaminar............................................... 39

3.3.2 Ação sistêmica....................................................... 40

3.3.3 Ação de contato................................................... 42

3.4 Avaliação da atividade de extratos orgânicos de T. pallida ...... 43

3.5 Avaliação do efeito inseticida de extratos clorofórmico e aquoso de $T$. pallida e aquoso de sementes de nim .................. 44

3.6 Avaliação do efeito ovicida de extratos aquosos e orgânicos de meliáceas

3.6.1 Influência da idade do ovo no efeito ovicida do extrato aquoso de sementes de nim

3.6.2 Efeito ovicida de extratos aquosos e orgânico de meliáceas

3.6.3 Efeito ovicida de extrato aquoso de sementes de nim por vias sistêmica e translaminar.

3.6.4 Efeito ovicida de extratos aquoso e clorofórmico de meliáceas por vias sistêmica e translaminar. 
4 RESULTADOS E DISCUSSÃO............................................... 48

4.1 Determinação das concentrações adequadas dos extratos a serem utilizadas nos experimentos......................................... 48

4.1.1 Ação translaminar.......................................................... 48

4.1.2 Ação sistêmica.................................................................... 51

4.1.3 Ação de contato............................................................. 55

4.2 Avaliação da atividade de extratos orgânicos de T. pallida ...... 57

4.3 Avaliação do efeito inseticida de extratos clorofórmico e aquoso de $T$. pallida e aquoso de sementes de nim .................... 61

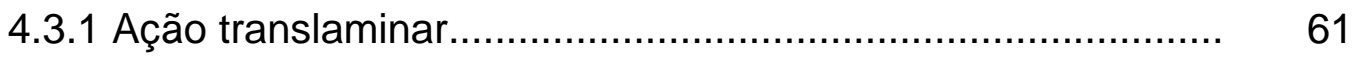

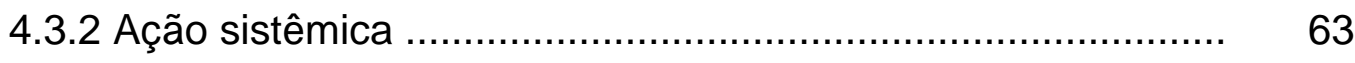

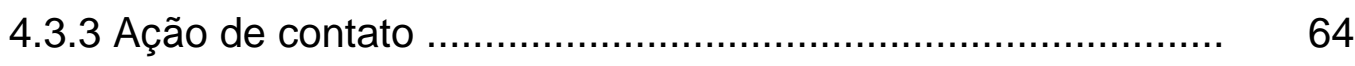

4.4 Avaliação do efeito ovicida de extratos aquosos e orgânicos

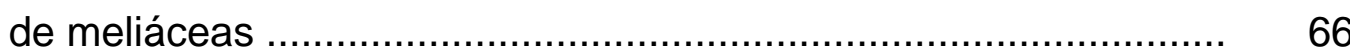

4.4.1Influência da idade do ovo no efeito ovicida do extrato

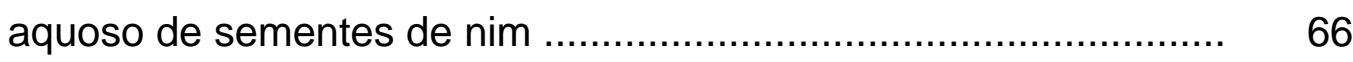

4.4.2 Efeito ovicida de extratos aquosos e orgânico de meliáceas $\quad 67$ 4.4.3 Efeito ovicida de extrato aquoso de sementes de nim por vias sistêmica e translaminar

4.4.4 Efeito ovicida de extratos aquoso e clorofórmico de meliáceas por vias sistêmica e translaminar 
5 CONCLUSÕES

REFERÊNCIAS BIBLIOGRÁFICAS ............................................ 78 


\title{
ATIVIDADE INSETICIDA E MODO DE AÇÃO DE EXTRATOS DE MELIÁCEAS SOBRE Bemisia tabaci (GENN., 1889) BIÓTIPO B
}

\author{
Autor: ANTONIO PANCRÁCIO DE SOUZA \\ Orientador: Prof. Dr. JOSÉ DJAIR VENDRAMIM
}

\section{RESUMO}

Foram conduzidos experimentos com o objetivo de avaliar a bioatividade e o modo de ação de extratos aquosos e orgânicos de ramos de Trichilia pallida Swartz e extratos aquosos de sementes de nim, Azadirachta indica A. Juss, em relação a ninfas e ovos da mosca-branca Bemisia tabaci (Genn.) biótipo B. Inicialmente, verificou-se que o extrato aquoso de sementes de nim apresenta ação inseticida sobre ninfas de mosca-branca pelas vias translaminar, sistêmica e de contato, nas concentrações de 1; 0,5 e 0,3\% (p/v), respectivamente. Em seguida, na comparação entre os extratos metanólico, etanólico, clorofórmico e hexânico de ramos de T. pallida, na concentração de $5 \%(p / v)$, foi selecionado o extrato clorofórmico como mais eficiente sobre ninfas de mosca-branca. Esse extrato foi comparado com os extratos aquosos 
de sementes de nim e de ramos de $T$. pallida sobre as ninfas quanto aos três tipos de ação nas respectivas concentrações determinadas no experimento. Apenas o extrato de nim provocou mortalidade ninfal pelas três vias testadas. Em relação à fase de ovo, constatou-se que a sua idade não afeta a ação ovicida do extrato aquoso de sementes de nim. Na comparação da ação translaminar e sistêmica dos extratos aquoso e clorofórmico de ramos de $T$. pallida e aquoso de sementes de nim, a 3\% (p/v), sobre os ovos de moscabranca, verificou-se que apenas o extrato de nim tem efeito ovicida. 


\title{
INSECTICIDAL ACTIVITY AND ACTION WAY OF EXTRACTS FROM MELIACEAE PLANTS ON SILVERLEAF WHITEFLY Bemisia tabaci (GENN., 1889) BIOTYPE B
}

\author{
Author: ANTONIO PANCRÁCIO DE SOUZA \\ Adviser: Prof. Dr. JOSÉ DJAIR VENDRAMIM
}

\section{SUMMARY}

The objective of this research was to determinate the bioactivity and the action means of aqueous and organic extracts of Trichilia pallida Swartz twigs, and the aqueous extracts of neem seeds, Azadiracta indica A. Juss, on nymphs and eggs of silverleaf whitefly. Initially, it was observed that aqueous extracts of neem seeds caused insecticidal activity on the nymphs by translaminar (1\%), systemic $(0,5 \%)$ and topical action (0,3\%). After, in the comparison of metanolic, etanolic, chloroformic, and hexanic T. pallida twig extracts at the concentrations of $5 \%$, the chloroformic extract was more efficient on the nymphs. This extract was compared with aqueous extracts of neem seeds, and the T. pallida twigs, by three means (translaminar, systemic and topical action) at concentrations previously determinated. Just the neem extract 
caused nymphal mortality for three means. In relation to the phase of eggs, it was verified that the age did not affect the ovicidal action of aqueous extract of neem seeds. In the comparison of translaminar and sistemic action of aqueous and chloroformic extracts of $T$. pallida twigs and aqueous extracts of neem seeds (3\%) on eggs of the insect, just the neem extract showed ovicidal activity. 


\section{INTRODUÇÃo}

A mosca-branca Bemisia tabaci (Genn., 1889) biótipo B é considerada uma das principais pragas do tomateiro. Seus danos são causados diretamente pela sucção da seiva, injeção de toxinas e liberação de honeydew provocando a formação de fumagina e, indiretamente, pela transmissão de doenças viróticas (Ohnesorge \& Rapp, 1986 e Yokomi et al., 1990).

Alguns métodos alternativos têm sido estudados para controle dessa praga, incluindo-se, dentre eles, os extratos de plantas de diversas famílias botânicas com ênfase para as meliáceas (Asiatico \& Zoebisch, 1992; Coudriet et al., 1985; Cubillo et al., 1994; Gómez et al., 1997a e b e Nardo et al., 1997). Isso se torna ainda mais importante quando se considera o rápido desenvolvimento de resistência dessa praga aos inseticidas (Prabhaker et al., 1998) e dos outros problemas causados por estes produtos no agroecossistema.

O potencial inseticida de plantas da família Meliaceae tem sido avaliado em relação a pragas como Spodoptera frugiperda (J.E. Smith) e Tuta absoluta (Meyrick) no laboratório de Plantas a Inseticidas da ESALQ/USP, obtendo-se resultados promissores com algumas espécies, como Trichilia pallida Swartz e Melia azedarach L. (Rodríguez \& Vendramim, 1996; Roel et al., 2000; Thomazini et al., 2000; Torrecillas, 1997 e Vendramim \& Scampini, 1997). Com essas plantas, foram obtidos, em relação a $S$. frugiperda, resultados

similares aos registrados com Azadirachta indica A. Juss (Rodríguez, 1995 e Torrecillas, 1997), considerada atualmente a mais eficiente planta 
inseticida (Mordue (Luntz) \& Blackwell, 1993; Rodríguez, 1995 e Martinez, 2002). A atividade inseticida dessas meliáceas foi testada em relação à mosca-branca $B$. tabaci biótipo B por Souza \& Vendramim (2000a e b) que observaram efeito ovicida de ramos de $T$. pallida e de folhas de $M$. azedarach sobre essa praga, sendo que os ramos de $T$. pallida provocaram maior mortalidade de ovos do que 0 nim já conhecido pelo seu efeito sobre a mosca-branca. Na comparação do efeito de diferentes estruturas vegetais, foi constatado, para $M$. azedarach, que os frutos verdes foram a estrutura vegetal mais efetiva, seguindo-se as folhas e os frutos maduros, enquanto para $T$. pallida, os ramos foram mais efetivos, vindo a seguir as folhas (Souza \& Vendramim, 2001).

O efeito inseticida por via sistêmica de extratos de sementes de nim ou de solução de azadiractina aplicados no solo já é conhecido (Coudriet et al., 1985; Gill \& Lewis, 1971; Prabhaker et al., 1999; Nisbet et al., 1996; Saxena et al., 1984; Weintraub \& Horowitz, 1997 e West \& Mordue (Luntz), 1992). Essa informação, entretanto, é desconhecida no que se refere a extratos de $T$. pallida e de $M$. azedarach. Considerando o potencial dessas meliáceas, especialmente $T$. pallida, no controle de insetos, seria interessante o incremento de pesquisas básicas para determinar o mecanismo de ação inseticida e os grupos de compostos químicos envolvidos.

O objetivo desse trabalho foi determinar a existência ou não de efeito inseticida translaminar, sistêmico e por contato de extratos aquosos e orgânicos de $T$. pallida e do extrato aquoso de sementes de nim em relação à mosca-branca B. tabaci biótipo B. 


\section{REVISÃO DE LITERATURA}

\subsection{Mosca-branca Bemisia tabaci}

\subsubsection{Aspectos taxonômicos, distribuição geográfica e plantas hospedeiras}

As moscas-brancas pertencem à ordem Hemiptera, subordem Sternorrhyncha e família Aleyrodidae, a qual é subdividida em duas subfamílias: Aleyrodicinae e Aleyrodinae. Já foram descritas cerca de 1200 espécies de moscas-brancas, sendo que a subfamília Aleyrodinae, a qual pertence a espécie B. tabaci (Genn., 1889), compreende mais de $90 \%$ do total. A distribuição das espécies no globo terrestre ocorre em função da latitude, concentrando-se a grande maioria (724 espécies) nos trópicos. A espécie mais importante do mundo é $B$. tabaci, por seu grande potencial de causar danos e suas peculiaridades, tais como de ser a única espécie da família capaz de transmitir geminivírus às plantas (Bink-Moenen \& Mound, 1990 e Hilje, 1996).

A identificação de moscas-brancas apresenta algumas dificuldades, dentre as quais, a falta de chaves para adultos e de chaves completas para espécies do continente americano e do resto do mundo. Além disso, há necessidade de muita prática no manuseio e montagem das ninfas de quarto ínstar que são utilizadas para a identificação, uma vez que os ínstares 
menores não possuem as estruturas de importância taxonômica. Outro problema é a morfologia de algumas espécies que varia conforme a planta hospedeira (Eichelkraut \& Cardona, 1989; Hilje, 1996 e Martin, 1987). É vantajoso se trabalhar com as ninfas aderidas às folhas, porque propicia informações úteis sobre a planta hospedeira, porém tem a desvantagem de a pupa sofrer adaptações de acordo com a espessura da folha, dificultando o trabalho do taxonomista. A variação morfológica da pupa de B. tabaci foi demonstrada por alguns autores em fumo, mandioca, couve, algodão, Euphorbia pulcherrina e Lantana camara (Ananthakrishnan, 1976; Azab et al., 1969 e Basu, 1995). Mohanty \& Basu (1986) demonstraram que, além do efeito da planta hospedeira, fatores sazonais também interferem na morfologia pupal.

Como são esperadas variações contínuas na preferência pelo hospedeiro, no ciclo de vida, capacidade de transmissão de doenças, indução de dano e razão de desenvolvimento entre populações de diferentes hábitats (Cohen et al., 1992 e Coudriet et al., 1985b), o emprego de técnicas de eletroforese enzimática e análise de DNA é uma excelente ferramenta para a discriminação de biótipos (Brown et al., 1995 e Hilje, 1996).

Gerling (2002) listou o amplo espectro tanto geográfico quanto de plantas hospedeiras que pode levar ao surgimento de diferenças alopátricas; os fatores genéticos, tais como a arrenotoquia que favorece a eliminação de genes recessivos desfavoráveis nos machos haplóides e as atividades humanas que proporcionam grandes quantidades de fontes alimentícias homogêneas e estáveis, associado à pressão de seleção pelos inseticidas que conduz ao desenvolvimento de resistência aos mesmos como os principais fatores que contribuem para a rápida especialização e conseqüente especiação nas moscas-brancas.

No continente americano, o biótipo B foi registrado na década de 80 , provavelmente introduzido através de plantas ornamentais importadas, sendo então disseminado para outras culturas de interesse econômico como feijão, mandioca, algodão, quiabo, melão, pimentão, abobrinha e fumo (Brown 
et al., 1995).

Em 1986, foram constatados danos severos causados pela mosca-branca em bico-de-papagaio na Flórida (Perring et al., 1991), observando-se, a seguir, que esse inseto começou a demonstrar alta resistência aos inseticidas comumente utilizados o que despertou o interesse dos EUA em confirmar a presença de um novo biótipo de $B$. tabaci no seu território. Estes estudos permitiram caracterizar pelo menos dois biótipos: o biótipo $A$, que se desenvolve bem em algodoeiro, mas não em bico-depapagaio, não induz o aparecimento do prateamento da folha em abobrinha e apresenta o padrão enzimático da esterase $A$, enquanto o biótipo $B$, que se desenvolve bem em bico-de-papagaio e brócolos, induz o prateamento da folha em abobrinha e apresenta o padrão enzimático da esterase B (Costa \& Brown, 1991; Cohen et al., 1992 e Perring et al., 1992). Por outro lado, a constatação de que o biótipo $B$ produz maior quantidade de honeydew do que o biótipo $A$ quando os insetos são criados em bico-de-papagaio ou brócolos (Byrne \& Miller, 1990), pode explicar a melhor adaptação do biótipo B, que apresenta, por exemplo, maior número de hospedeiros e razão de oviposição duas vezes maior que a do biótipo A em algodão (Betheke et al., 1991).

No Brasil, devido à ocorrência de surtos populacionais de moscabranca em hortaliças e ornamentais a partir do verão de 1990/91, Melo (1992) alertou para a possível ocorrência de um novo biótipo no país. Lourenção e Nagai (1994), relatando surtos populacionais de B. tabaci em hortaliças e ornamentais no Estado de São Paulo, observaram o ataque do inseto associado ao prateamento das folhas com queda drástica de produção em aboboreira e amadurecimento irregular dos frutos em tomateiro (sintomas característicos do ataque do biótipo B, segundo Schuster et al., 1990 e Yokomi et al., 1990). Por essa razão, também mencionaram a possibilidade de que um novo biótipo (ou uma nova espécie) teria sido introduzido no país, o que acabou sendo confirmado pela Dra. Judith Brown, da Universidade do Arizona (EUA), a 
partir de espécimes da mosca-branca coletados em tomateiro no Distrito Federal (França et al., 1996).

Devido às diferenças anteriormente citadas entre os biótipos somadas às diferenças genômicas e da incompatibilidade sexual entre os mesmos, Perring et al. (1993) admitiram a possibilidade de uma nova espécie de Bemisia. A caracterização do biótipo B como nova espécie (Bemisia argentifolii Bellows \& Perring) foi feita, conforme consta em Bellows et al. (1994), com base nos danos característicos nas plantas hospedeiras, nas aberturas traqueais torácicas menores, no filamento de cera menor e mais frágil e na ocorrência da seta submarginal ASMS4 somente nesse biótipo.

Após uma revisão do assunto, entretanto, Brown et al. (1995) sugeriram que $B$. tabaci seja um complexo sofrendo mudanças evolucionárias. Atualmente, considera-se que $B$. argentifolii é de fato o biótipo $B$ de $B$. tabaci.

Devido à interferência do homem na dispersão dos insetos, uma conclusão definitiva sobre o centro de origem de $B$. tabaci vai se tornando cada vez mais difícil (Brown, 1994 e Wool et al., 1994), porém acredita-se que essa espécie de mosca-branca seja originária do subcontinente indiano, já que nessa região há abundância e diversidade de inimigos naturais (Brown et al., 1995). Segundo estes autores, $B$. tabaci é um inseto multivoltino com 11 a 15 gerações por ano e tem como hábitat regiões tropicais e subtropicais. É encontrada na África, América, Ásia e região do Mediterrâneo (Coudriet et al., 1985b, 1986; Murrant et al., 1988 e Vasquez et al., 1997). No Brasil, este inseto atualmente ocorre nos Estados de São Paulo, Minas Gerais, Goiás, Paraná, Distrito Federal, Bahia, Pernambuco (Submédio São Francisco), Ceará, Mato Grosso do Sul, Rio Grande do Norte, Tocantins e Rio de Janeiro (Villas Bôas et al., 1997).

Em algumas localidades dos Estados Unidos e Brasil, onde se encontrava apenas $B$. tabaci biótipo A, tem-se constatado atualmente apenas 0 biótipo B (Brown, 1994 e França et al., 1996). Perring et al. (1994) explicaram esse deslocamento competitivo pelo comportamento de corte e cópula 
diferenciado entre os biótipos. O biótipo A realiza essa atividade em menos de um terço do tempo gasto pelo biótipo $B$. Os machos do biótipo $B$, embora demorem mais tempo no ritual de corte com fêmeas de $A$, não efetuam a cópula, mas ao mesmo tempo impedem que o macho de $\mathrm{A}$ o faça. Por outro lado, a cópula entre indivíduos de B não é afetada, uma vez que o tempo de corte entre macho de $A$ e fêmea de B é curto.

Os hospedeiros preferenciais da mosca-branca são: cucurbitáceas (abobrinha, melancia, melão e chuchu), solanáceas (tomate, berinjela, pimentão, fumo, pimenta e jiló), brássicas (brócolos e repolho), leguminosas (feijão, feijão-vagem), algodão, mandioca, alface e quiabo, além de plantas ornamentais, daninhas e silvestres (Caballero, 1994; Mello, 1992 e Villas Bôas et al., 1997). Brown et al. (1995) relataram que a gama de plantas hospedeiras de Bemisia spp. tem aumentado no decorrer do tempo, o que tem sido atribuído, entre outras razões, ao uso de práticas agrícolas de monocultivo irrigado. Com a recente discussão a respeito de uma nova espécie de Bemisia, foi constatado que B. tabaci biótipo A tem pouco mais de 100 plantas hospedeiras, enquanto que o biótipo $B$ já foi encontrado em mais de 600 espécies vegetais, das quais $50 \%$ estão restritas a somente cinco famílias: Fabaceae (99 espécies), Asteraceae, Malvaceae, Solanaceae e Euphorbiaceae (Blua et al., 1995; Brown et al., 1995; De Barro, 1995 e Oliveira et al., 2001). A existência de uma associação entre biótipo e planta hospedeira poderá resultar biótipos específicos para um número restrito de plantas, considerando-se que deve haver um custo adaptativo na manutenção de um largo espectro de hospedeiros.

A vasta gama de plantas hospedeiras e conseqüentemente a sua distribuição por todos os continentes têm levado os centros de pesquisa do mundo inteiro a se organizarem em projetos de cooperação internacional para facilitar a comunicação, a pesquisa e a transferência de tecnologia (Oliveira et al., 2001). 


\subsubsection{Aspectos morfológicos e ecológicos}

Os ovos de B. tabaci são piriformes, com textura lisa e medem de 0,18 a 0,21 mm de comprimento e 0,06 a 0,09 $\mathrm{mm}$ de largura. Inicialmente apresentam coloração branca, mas à medida que se dá o desenvolvimento embrionário, tornam-se amarelados e próximos à eclosão adquirem coloração vermelho-clara ou café claro (Byrne \& Bellows, 1991; Eichelkraut \& Cardona, 1989; Patel, et al., 1992 e Villas Bôas et al., 1997). São dispostos isoladamente ou em grupos irregulares, ou ainda, ocasionalmente, em semicírculos sendo sustentados por um pedicelo inserido na folha durante a oviposição, diretamente no tecido foliar, nunca na abertura dos estômatos (Eichelkraut \& Cardona, 1989 e Paulson \& Beardsley, 1985). Buckner et al. (2002) observaram que o pedicelo fica inserido no interior das células da epiderme, sem alcançar as células parenquimáticas.

As ninfas de primeiro ínstar são móveis, mas posteriormente se fixam num local adequado para a tomada de alimento, onde permanecem até o final do estádio. Esta mobilidade ninfal é fundamental para o ciclo de vida do inseto, pois se a folha não oferecer condições para o completo desenvolvimento ninfal, devido à senescência, por exemplo, a ninfa pode se locomover para uma folha mais adequada (Summers et al., 1996). Após a eclosão, se a ninfa estiver na face adaxial, existe tendência de se locomover para a superfície abaxial, orientada mais provavelmente por um estímulo tátil ou alimentar do que por estímulos geotrópico ou fototrópico (Simmons, 1999).

Em inglês, o primeiro ínstar é denominado crawler devido à ninfa se arrastar para se locomover. A ninfa de primeiro ínstar mede 0,24 a 0,27 mm de comprimento e 0,12 a 0,18 mm de largura. É de formato elíptico, coloração branco-esverdeada, plana ventralmente e convexa dorsalmente (Eichelkraut \& Cardona, 1989 e Patel et al., 1992). 
A ninfa de segundo ínstar é oval, e apresenta coloração brancoesverdeada e olhos brilhantes. Seu comprimento varia de 0,33 a 0,39 $\mathrm{mm}$ e sua largura de 0,18 a 0,24 mm (Eichelkraut \& Cardona, 1989 e Patel et al., 1992).

O terceiro ínstar tem formato elíptico, cor verde-pálida a verdeescura e olhos vermelhos brilhantes na parte dorsal da cabeça. É possível observar a secreção de uma substância colágena transparente saindo pelo orifício vasiforme triangular aderindo à parte posterior do abdome. Seu comprimento varia de 0,51 a 0,60 e 0,30 a 0,36 de largura (Patel et al., 1992). Eichelkraut \& Cardona (1989) não encontraram diferença morfológica entre o segundo e o terceiro ínstar ninfal de mosca-branca.

A ninfa de quarto ínstar se alimenta apenas no início desse estádio; depois cessa a alimentação, quando aparentemente sofre mudanças morfológicas para se transformar em "pupa" (Eichelkraut \& Cardona, 1989). O termo "pupa" é inadequado, uma vez que o inseto não sofre qualquer tipo de metamorfose caracterizando a passagem para um novo estádio (Brown et al. 1995; Byrne \& Bellows, 1991; De Barro, 1995; Norman et al., s.d. e Villas Bôas et al., 1997). Em razão dessa peculiaridade, o tipo de desenvolvimento das moscas-brancas era denominado neometabolia para diferenciar da paurometabolia em que não ocorre essa fase de interrupção da alimentação (Zucchi et al., 1993). Atualmente, entretanto, existe tendência em se denominar qualquer metamorfose incompleta como hemimetabolia, independentemente da sua peculiaridade (Gallo et al., 2002).

A ninfa de quarto ínstar tem formato oval, com a parte cefálica arredondada e a parte caudal terminada em uma ponta. É nítida a divisão do corpo em cabeça, tórax e abdome. O seu comprimento de 0,54 a 0,85 mm e a largura de 0,36 a 0,60 mm. No início deste estádio, a ninfa é plana e transparente, mas no final é convexa e opaca, com os olhos vermelhos bem visíveis (Eichelkraut \& Cardona, 1989). Patel et al. (1992) acrescentam um par de setas caudais. 
Quando próximo à emergência, o adulto torna-se visível pelo tegumento da pupa. O inseto rompe o tegumento deixando uma abertura em forma de $\mathrm{T}$ invertido que vai da cabeça até a separação do tórax e abdome. Sua saída ocorre por contrações e distensões do corpo. Recém-emergido, sua coloração é amarelo-pálida, mas após 3 a 5 h assume a coloração esbranquiçada devido à secreção pulvurulenta que lhe cobre o corpo (Eichelkraut \& Cardona, 1989).

Os adultos de B. tabaci têm o dorso amarelo-pálido e as asas brancas, medindo de 1 a $2 \mathrm{~mm}$ de comprimento e 0,36 a 0,51 $\mathrm{mm}$ de largura, sendo a fêmea maior que o macho. Quando em repouso, as asas são levemente separadas, com os lados paralelos, deixando o abdome amarelado visível. Os olhos são vermelhos, compostos e divididos em duas partes por uma projeção cuticular. As asas têm venação reduzida. As pernas são delgadas sendo as posteriores mais largas que as anteriores. A fêmea se diferencia do macho pelo maior tamanho e pela configuração da genitália (Eichelkraut \& Cardona, 1989; Patel et al., 1992 e Souza \& Vendramim, 2000b).

A reprodução é sexuada dando origem somente a fêmeas ou por partenogênese arrenótoca (Byrne \& Bellows, 1991 e Eichelkraut \& Cardona, 1989). Como na maioria das espécies de mosca-branca, as fêmeas de $B$. tabaci podem regular o sexo de seus descendentes, desde que tenham espermatozóides armazenados para selecionar a fertilização (Horowitz \& Gerling, 1992).

A maioria dos adultos emerge pela manhã (Butler et al., 1983; Hoffman \& Byrne, 1986 e Powell \& Bellows, 1992), sendo que os machos emergem antes das fêmeas (Gerling et al., 1986). A emergência não ocorre em temperaturas abaixo de $17^{\circ} \mathrm{C}$, entretanto, não há correlação entre o início da emergência e o fotoperíodo sugerindo a existência de um ritmo circadiano (Hoffman \& Byrne, 1986).

A razão sexual varia no decorrer do período de maior incidência (De Barro, 1995). Examinando a proporção entre os sexos de B. tabaci em 
campo de algodão, Horowitz \& Gerling (1992) constataram a predominância de fêmeas no início do verão ocorrendo o inverso, porém com menor diferença entre os sexos, ao final dessa estação. Os autores concluíram que a alta qualidade e quantidade de nutrientes do hospedeiro no início do verão facilita o rápido aumento da população. Enkegaard (1993) também constatou correlação positiva entre o número de fêmeas de $B$. tabaci e a temperatura, sendo que o número delas foi sempre proporcionalmente maior que o de machos, principalmente em temperaturas mais elevadas, o que é explicado pela maior mortalidade de machos nessas temperaturas.

A seleção da planta após o pouso é feita por picadas de prova. Pollard (1955), descrevendo o hábito alimentar de B. tabaci em algodoeiro, registrou, como efeitos macroscópicos desta alimentação, a deposição de honeydew na folha, ocorrência de clorose pela saliva da ninfa removendo clorofila e amido, desenvolvimento de antocianina, queda de folhas e redução na razão de crescimento. Os estiletes das ninfas alcançam o floema por penetração intercelular. A bainha estiletar ou salivar é rara e de constrição anular. Em 82\% dos casos, o floema foi alcançado e o dano nos tecidos se restringiu à destruição de alguns cloroplastos adjacentes e plasmólise ocasional. O floema não foi bloqueado nem danificado.

Após o pouso, a discriminação da planta pelo inseto é feita com base em características físicas externas e químicas internas. Berlinger (1986) citou, como características físicas externas importantes para Bemisia spp., a pilosidade, os tricomas glandulares, o formato de folha e, provavelmente, 0 microclima, destacando o pH da folha como a principal característica química interna. Estudos de microscopia eletrônica do ápice do lábio de seis espécies de mosca-branca, incluindo $B$. tabaci, revelaram que todas possuem sete pares de sensilos simetricamente posicionados sobre ou ao lado do encaixe labial, com função aparentemente quimio-sensorial (Walker \& Gordh, 1989).

As fêmeas de $B$. tabaci ovipositam preferencialmente na face abaxial das folhas jovens, com pilosidade moderada (Butler \& Wilson, 1984 e 
Patel et al., 1992), o que se deve, segundo Butler et al. (1988), ao fato de esse tipo de folha conferir proteção contra o vento e dessecação.

\subsubsection{Aspectos biológicos de B. tabaci biótipo B}

A duração do ciclo de vida desse inseto varia de acordo com a planta hospedeira e a temperatura.

A fase de ovo, à temperatura entre 25 e $27^{\circ} \mathrm{C}$, dura em torno de 5 a 8 dias, independentemente da planta hospedeira (Bethke et al., 1991; Liu \& Stansly, 1998; Nava-Camberos et al., 2001; Salas \& Mendonza, 1995; Tsai \& Wang, 1996; Wang \& Tsai, 1996 e Yee \& Toscano, 1996). Excepcionalmente, Enkegaard (1993) observou em algodão duração dessa fase em torno de 14 dias a $25^{\circ} \mathrm{C}$. Wagner (1995) observou em algodão que o período de incubação variou de 5 a 9 dias nas temperaturas entre 21,77 e $34,66^{\circ} \mathrm{C}$; abaixo dessa temperatura, o alongamento da fase foi mais acentuado atingindo até 22,4 dias a $15,42^{\circ} \mathrm{C}$. Em berinjela, em temperaturas variando de 15 a $35^{\circ} \mathrm{C}$, Wang \& Tsai (1996) registraram valores de 4,2 a 25,8 dias, sendo que abaixo de 20 e acima de $30^{\circ} \mathrm{C}$, ocorreu alongamento da fase.

A viabilidade dos ovos é superior a 90\% na faixa de temperatura entre 20 e $30^{\circ} \mathrm{C}$ (Enkegaard, 1993; Nava-Camberos et al., 2001; Salas \& Mendonza, 1995; Tsai \& Wang, 1996; Wagner, 1995 e Wang \& Tsai, 1996). Em temperaturas acima de $30^{\circ} \mathrm{C}$ ou abaixo de $20^{\circ} \mathrm{C}$, há tendência de diminuição da viabilidade (Enkegaard, 1993 e Wang \& Tsai, 1996).

A fase ninfal apresenta, entre 25 e $27^{\circ} \mathrm{C}$, duração em torno de 12 a 21 dias (Bethke et al., 1991; Liu \& Stansly, 1998; Nava-Camberos et al., 2001; Salas \& Mendonza, 1995; Tsai \& Wang, 1996; Wagner, 1995; Wang \& Tsai, 1996 e Yee \& Toscano, 1996). Enkegaard (1993) observou, em bico-depapagaio, prolongamento dessa fase, em temperaturas abaixo de $20^{\circ} \mathrm{C}$. Em berinjela, Wang \& Tsai (1996) observaram que, a $30^{\circ} \mathrm{C}$, o período ninfal foi de apenas 9,4 dias, enquanto que abaixo de $25^{\circ} \mathrm{C}$ e acima de $30^{\circ} \mathrm{C}$, o referido período se alongou, chegando a atingir 79,1 dias a $15^{\circ} \mathrm{C}$. 
O efeito da planta hospedeira na duração da fase ninfal foi observado por Tsai \& Wang (1996), que trabalhando a $25^{\circ} \mathrm{C}$, em plantas de berinjela, tomate, batata-doce, pepino e feijão, encontraram 11,35; 11,75; 12,00; 12,97 e 14,95 dias, respectivamente.

A viabilidade ninfal é variável para temperaturas entre 20 e $30^{\circ} \mathrm{C}$, de 39 a 95\% (Enkegaard, 1993; Tsai \& Wang, 1996; Wagner, 1995 e Wang \& Tsai, 1996). A $16^{\circ} \mathrm{C}$, Enkegaard (1993) registrou apenas $6,19 \%$ de viabilidade ninfal do biótipo B em bico-de-papagaio. Variando a planta hospedeira, Tsai \& Wang (1996) observaram, a $25^{\circ} \mathrm{C}$, viabilidades ninfais de 48,$8 ; 93,9,62,7 ; 71,3$ e 48,1\%, em plantas de pepino, berinjela, tomate, batata-doce e feijão, respectivamente. Avaliando o efeito de temperaturas entre 15 e $35^{\circ} \mathrm{C}$ sobre este parâmetro biológico, Wang \& Tsai (1996) observaram valores de 44,1 (a $15^{\circ} \mathrm{C}$ ) e $41,1 \%$ (a $35^{\circ} \mathrm{C}$ ) até $93,9 \%$ (a $25^{\circ} \mathrm{C}$ ) em berinjela. É provável que a moscabranca dependa de outras plantas hospedeiras para completar seu ciclo de vida quando sua colonização ocorre em pimentão, pois Nava-Camberos et al. (2001) constataram que as ninfas criadas nessa planta hospedeira não chegam ao estádio adulto mesmo em temperatura ideal $\left(25^{\circ} \mathrm{C}\right)$.

O período do ovo a adulto pode durar, em temperaturas entre 25 e $27^{\circ} \mathrm{C}$, de 16 a 25 dias, conforme a planta hospedeira (Nava-Camberos et al., 2001; Pereira et al., 1996; Salas \& Mendonza, 1995; Tsai \& Wang, 1996; Wagner, 1995; Wang \& Tsai, 1996 e Yee \& Toscano, 1996), tendo sido registrado um valor de 17,96 dias em tomate, a $25^{\circ} \mathrm{C}$ (Tsai \& Wang, 1996). Enkegaard (1993) observou que, em bico-de-papagaio, em temperaturas inferiores a $20^{\circ} \mathrm{C}$, o inseto teve seu período de desenvolvimento prolongado. No intervalo de 17,63 a $34,75^{\circ} \mathrm{C}$, Wagner (1995) observou que esse período tende a se prolongar abaixo de $17,2^{\circ} \mathrm{C}$ ou acima de $21,3^{\circ} \mathrm{C}$, mas as temperaturas extremas provocam alongamento acentuado. Wang \& Tsai (1996), trabalhando em temperaturas variáveis entre 15 e $35^{\circ} \mathrm{C}$, observaram que a duração do período ovo-adulto, em berinjela, foi bastante afetada por esse fator, variando de 13,6 a 104,9 dias. A faixa de 25 a $30^{\circ} \mathrm{C}$ foi considerada ideal para o inseto, 
com alongamento do período de desenvolvimento fora dessa faixa.

A viabilidade do período de ovo a adulto, conseqüentemente, também é afetada pela planta hospedeira e temperatura, variando de 50 a 95\%, a 25ㄷ (Enkegaard, 1993; Nava-Camberos et al., 2001; Tsai \& Wang, 1996 e Wang \& Tsai, 1996). O efeito da planta hospedeira sobre esse parâmetro foi comprovada por Tsai \& Wang (1996) que encontraram, a $25^{\circ} \mathrm{C}$, valores de 88,7; 60,$2 ; 67,5 ; 46,4$ e 45,8\%, em berinjela, tomate, batata-doce, pepino e feijão, respectivamente.

O período de pré-oviposição pode variar de 1,5 até 4 dias, em função da temperatura (Enkegaard, 1993 e Salas \& Mendonza, 1995).

A longevidade também apresenta bastante variação de acordo com a planta hospedeira e a temperatura. Para fêmeas, esse período varia, em geral, de 10 a 20 dias em temperaturas entre 25 e $30^{\circ} \mathrm{C}$ (Bethke et al., 1991; Enkegaard, 1993; Salas \& Mendonza, 1995; Tsai \& Wang, 1996 e Wang \& Tsai, 1996). Em berinjela, Wang \& Tsai (1996) observaram variação na longevidade de fêmeas de 10,43 a 44,36 dias, com redução desse período a $35^{\circ} \mathrm{C}$ e alongamento a $15^{\circ} \mathrm{C}$. A comprovação do efeito da planta hospedeira sobre a longevidade de fêmeas foi feita por Tsai \& Wang (1996), que observaram, a $25^{\circ} \mathrm{C}$, valores de 24,$03 ; 20,55 ; 16,56 ; 9,85$ e 13,38 dias em berinjela, tomate, batata-doce, pepino e feijão, respectivamente.

À semelhança do que foi constatado para os demais parâmetros biológicos, a fecundidade varia bastante em função da planta hospedeira e da temperatura, com valores entre 22 e 324 ovos/fêmea (Bethke et al., 1991; Enkegaard, 1993; Salas \& Mendonza, 1995; Tsai \& Wang, 1996 e Wang \& Tsai, 1996). Tsai \& Wang (1996) obtiveram, a $25^{\circ} \mathrm{C}$, valores de fecundidade de 223,67; 167,55; 77,50; 65,96 e 83,50 ovos/fêmea, em berinjela, tomate, batatadoce pepino e feijão, respectivamente, enquanto Wang \& Tsai (1996) observaram que $B$. tabaci, mantida em berinjela, apresentou fecundidade variável entre 22 e 324 ovos/fêmea, em berinjela, na faixa de 15 a $35^{\circ} \mathrm{C}$, sendo que o menor valor foi registrado a $32^{\circ} \mathrm{C}$. 
Bethke et al. (1991) observaram que o biótipo B é de duas a três vezes mais fecundo que o A em algodão. Blua et al. (1995) observaram que os dois biótipos ovipositam em quantidade semelhante em pepino, mas em couve e beterraba, o biótipo B oviposita mais que o A. Os autores rasparam levemente a superfície da folha de couve e constataram que os dois biótipos passaram a ovipositar semelhantemente, ficando clara a existência de algum mecanismo de seleção do inseto para oviposição conforme características morfológicas e/ou químicas da superfície foliar.

A razão sexual é geralmente próxima de 0,70 , com predominância das fêmeas em relação aos machos independentemente da temperatura (Enkegaard, 1993 e Salas \& Mendonza, 1995). Eichelkraut \& Cardona (1989), entretanto, observaram a razão sexual de um macho para cada fêmea em feijão, em temperatura média de $24^{\circ} \mathrm{C}$.

Wagner (1995) avaliou a razão sexual do biótipo B em duas cultivares de algodão, em diferentes temperaturas, confirmando essa proporção entre os sexos. Sendo assim, o autor concluiu que esse parâmetro não é afetado pela planta hospedeira, temperatura ou época do ano. Por outro lado, Sharaf \& Batta (1985) observaram que em temperaturas entre 25 e $14^{\circ} \mathrm{C}$, a proporção de fêmeas aumenta com o decréscimo da temperatura.

\subsection{Extratos botânicos}

\subsubsection{Considerações gerais}

A utilização de fitoinseticidas para controle de insetos pragas é uma atividade relativamente antiga, destacando-se entre os primeiros produtos a nicotina extraída do fumo Nicotiana tabacum (Solanaceae), a rianodina extraída de Ryania speciosa (Flacuorticaceae), a sabadila oriunda de Schoenocalum officinale (Liliaceae), a piretrina proveniente de Chrysanthemum cinerariaefolioum (Asteraceae) e a rotenona extraída de Derris spp. e Lonchocarpus spp. (Fabaceae) (Lagunes \& Rodríguez, 1989). Estes produtos 
porém, praticamente deixaram de ser utilizados com o advento dos inseticidas organossintéticos, que se mostravam mais eficientes e baratos.

O ressurgimento dos estudos com plantas inseticidas deveu-se à necessidade de novos compostos para controle de pragas, sem os problemas de contaminação ambiental, resíduos nos alimentos, efeitos prejudiciais sobre insetos benéficos e aparecimento de populações de insetos resistentes.

Segundo Vendramim (1997), as pesquisas com plantas inseticidas são feitas normalmente com dois objetivos: a descoberta de novas moléculas que permitam a formulação de produtos sintéticos ou a obtenção de inseticidas botânicos naturais para uso direto no controle de pragas.

Grainge \& Ahmed (1988) catalogaram 2.400 espécies de plantas com potencial para uso no controle de pragas, mencionando as características gerais da planta, ação sobre os insetos, além de uma listagem de 800 pragas controladas por derivados dessas plantas e ainda 100 plantas com substâncias químicas reportadas no controle de doenças e nematóides parasitas do homem e de animais.

\subsubsection{Trichilia pallida}

Segundo Jacobson (1989), as plantas inseticidas mais promissoras se encontram nas famílias Meliaceae, Rutaceae, Asteraceae, Annonaceae, Labiatae e Canellaceae, das quais a primeira merece destaque por que incluir Azadirachta indica, conhecida por nim. De acordo com Martinez (2002), até 1995, cerca de 400 espécies de insetos já tinham sido relatadas como sensíveis a algum tipo de ação do nim. A azadiractina, um limonóide, é o composto do nim que apresenta a maior atividade inseticida. Entretanto, a complexidade dessa molécula impede sua síntese purificada em escala comercial. Desse modo, justifica-se a pesquisa de outras espécies de meliáceas em substituição ao nim, ou ainda que possuam outros fitoquímicos com potencial inseticida. 
Segundo Xie et al. (1994), o gênero Trichilia spp. apresenta grande potencial entre as meliáceas. Os autores observaram o efeito de várias espécies de Trichilia spp. sobre duas espécies de lepidópteros, sendo que os extratos de casca e ramos, em geral, foram mais efetivos do que os de folha. Vários limonóides com propriedade inseticida foram identificados nesse gênero (Inada et al., 1994; Kubo \& Klocke, 1982; Mikolajczak \& Reed, 1987; Nakatani et al., 1981; Simmonds et al., 2001 e Xie et al., 1994).

No Laboratório de Plantas Inseticidas (ESALQ/USP), têm sido desenvolvidas pesquisas sobre o uso de meliáceas no controle de insetos desde 1993 quando foram feitos os primeiros experimentos com Spodoptera frugiperda (J.E. Smith) (Rodríguez \& Vendramim, 1995), em que se destacaram duas espécies: Trichilia pallida e Melia azedarach. Com essas duas plantas (especialmente com T. pallida) foram conduzidas novas pesquisas com extratos aquosos, comparando o efeito de diferentes estruturas vegetais sobre $S$. frugiperda (Bogorni, 2003; Rodríguez \& Vendramim, 1996, 1997; Torrecillas \& Vendramim, 2001; Vendramim \& Scampini, 1995, 1997 e Vendramim \& Torrecillas, 1998) e sobre Tuta absoluta (Meyrick) (Brunherotto \& Vendramim, 2001 e Thomazini et al., 2000). .

Em relação a B. tabaci, Souza \& Vendramim (2000a e b, 2001) verificaram o efeito inseticida de extratos aquosos de diferentes estruturas vegetais de $T$. pallida e de $M$. azedarach e de sementes de nim sobre ovos e ninfas. As duas primeiras espécies tiveram efeito semelhante sobre a fase ninfal, mas a fase de ovo foi mais afetada por T. pallida, superando até o extrato de nim.

Os resultados promissores motivaram a condução de pesquisas com extratos orgânicos de T. pallida sobre diferentes espécies de insetos, visando identificar compostos fitoquímicos inseticidas. Pesquisas nessa linha foram desenvolvidas por Roel \& Vendramim (1999, 2000a e b) que constataram que dentre quatro extratos orgânicos (acetona, metanol, acetato de etila e hexano) de $T$. pallida, a maior eficiência foi obtida com acetona seguido de metanol. 
T. pallida, conhecida como baga-de-morcego ou catiguá, ocorre desde o México até o Norte da Argentina e Paraguai. No Brasil, está dispersa desde a Amazônia até o Paraná, mas não ocorre na região Nordeste (Klein, 1984). Seu efeito contra insetos foi citado por Wolcott (1957), que relatou ocorrer repelência e resistência ao cupim Cryptotermes brevis Walker. Entretanto, apenas após os trabalhos desenvolvidos na ESALQ/USP é que o potencial desta meliácea em relação a outros insetos de importância agrícola passou a ser melhor investigado.

\subsubsection{Efeito de derivados de nim sobre insetos sugadores}

O efeito do nim é conhecido sobre algumas pragas, incluindo a mosca-branca. Os insetos mais estudados são sugadores que transmitem vírus fitopatogênicos, o que se justifica pela importância de um controle permanente da população de tais insetos de modo a impedir a disseminação de doenças na área cultivada. Em geral, são observados efeitos sobre a biologia, atratividade e capacidade de transmissão de fitovírus. O modo de aplicação pode ser via solo, imersão das raízes em soluções ou aplicação foliar. As quantidades aplicadas no solo variam de $10 \mathrm{ml}$ até $150 \mathrm{ml}$ (Coudriet et al., 1985a; Gill \& Lewis, 1971; Larew, 1988; Nisbet et al., 1993; Prabhaker et al., 1999; Saxena et al., 1984; Weintraub \& Horowitz, 1997 e West \& Mordue (Luntz), 1992), mas aparentemente essa variação é baseada no porte das plantas utilizadas, ou seja, quanto menor a planta, menor a quantidade de solução aplicada.

A determinação da concentração é um fator importante para sucesso no emprego de extratos de nim. Prabhaker et al. (1999) utilizaram 1\% de extrato de sementes de nim, concentração esta já testada com sucesso por outros autores (Natarajan \& Sundaramurthy, 1990 e Puri et al., 1994).

O nim tem efeito residual comprovado sobre algumas espécies de cigarrinhas em arroz em aplicações no solo. Ninfas de primeiro ínstar de Nilaparvata lugens (Stal), Sogatella furcifera (Horváth) e Nephotettix virescens 
(Distant) tiveram seu desenvolvimento afetado com a aplicação de $1 \mathrm{mg}$ de azadiractina por vaso mesmo após um mês do tratamento do solo (Saxena \& Epino, 1984). Heidt et al. (1984) observaram que estas espécies têm sua viabilidade ninfal diminuída em até 50\% com aplicações de azadiractina no solo. Saxena et al. (1984) aplicaram torta de nim misturada com uréia (1:10; 2:10 e 3:10) no solo em lavoura de arroz e liberaram adultos de $N$. lugens após 10 dias. A longevidade, fecundidade, oviposição e eclosão de ninfas não foi afetada e tampouco houve repelência de adultos, mas ainda assim a população foi menor no tratamento com nim e uréia 3:10 devido à mortalidade ninfal. Segundo Saxena et al. (1987), a torta de nim incorporada no solo (250 kg/ha) diminuiu a transmissão de fitovírus em arroz pela cigarrinha $N$. virescens. Os insetos se alimentavam no floema das plantas não tratadas e no xilema nas folhas tratadas o que pode ser a causa da menor incidência de fitoviroses. Ainda sobre N. virescens em arroz, Saxena \& Boncodin (1988) também verificaram menor incidência de fitoviroses, além de menor viabilidade de fêmeas após a imersão de raízes de plântulas de arroz em solução de extrato de sementes de nim com 2.500 ppm de azadiractina.

$O$ efeito residual do nim tem sido estudado sobre pulgões em aplicações no solo e também mergulhando as raízes de plantas em soluções de nim.

West \& Mordue (Luntz) (1992) aplicaram diferentes concentrações de azadiractina (25 a 500 ppm) no solo e avaliaram o seu efeito residual sobre Rhopalosiphum padi (L.) e Sitobium avenae (F.). As soluções foram diluídas em etanol $2 \%$ e misturadas a um coadjuvante (Teepol 0,5\%) para facilitar a dissolução da azadiractina. Os afídeos foram privados de alimentação por $2 \mathrm{~h}$ antes de serem colocados nas plantas de cevada. As avaliações foram feitas com 1, 2, 4 e 16 dias após a aplicação. No intervalo entre 5 e 25 min após a colocação do inseto, foi avaliada a atividade de picada de prova do inseto em comparação com a testemunha. Houve diminuição na atividade de picada de prova após dois dias em todos os tratamentos. 
Nisbet et al. (1993) colocaram as raízes de fumo Nicotiana clevelandii (Gray) em contato com azadiractina para avaliar seu efeito sobre o comportamento alimentar do pulgão Myzus persicae (Sulzer). O composto foi isolado de sementes de nim e preparado na concentração inicial de $2 \%$ em etanol. Foram preparadas quatro concentrações entre 100 e 1000 ppm. Em todos os tratamentos (incluindo a testemunha água), foram adicionados etanol $2 \%$ e o coadjuvante Tween 20 a 0,02\%. As raízes das plantas com 21 a 25 dias de idade foram lavadas em água e colocadas em contato com 1,5 ml de cada tratamento por $27 \mathrm{~h}$. Os afídeos foram confinados nas plantas, observando-se seu comportamento de picada de prova e alimentação (duração dos períodos de penetração e de não-penetração). Quanto maior a concentração, maior o tempo gasto pelo inseto em períodos de não-penetração. Os insetos diminuíram o tempo de alimentação via floema com o aumento da concentração, caracterizando-se dessa forma a circulação sistêmica do extrato. Griffits et al. (1978) também testaram a mortalidade de adultos dessa espécie aplicando diferentes concentrações de extrato metanólico de sementes de nim em soluções hidropônicas em plantas de couve. O efeito ocorreu somente em concentrações em que provocava fitotoxicidade, tais como descoloração e distorção foliar.

Nisbet et al. (1996) avaliaram o efeito residual da azadiractina sobre a capacidade de aquisição e inoculação de vírus por $M$. persicae em plantas de $N$. clevelandii. As raízes de plântulas infectadas com potato leafroll virus (PLRV) foram imersas em soluções com 0, 50, 100 ou 150 ppm de azadiractina por 48h. Afídeos ápteros foram colocados nas plantas por um período de aquisição de $72 \mathrm{~h}$, depois de $12 \mathrm{~h}$ ou 2 dias do tratamento, e a seguir colocados em plantas sadias. Houve diminuição na capacidade de aquisição e inoculação do vírus. Foi também testada a concentração de 500 ppm verificando-se que, mesmo assim, a inoculação ocorreu, o que pode ser explicado pela inoculação estar relacionada mais à secreção salivar e 
atividades de alimentação não-vascular do que à ingestão de tecido vascular (Sylvester, 1980).

Seria interessante a realização de experimentos para se avaliar o efeito residual, mas com aplicações no solo, pois mergulhar as raízes em soluções inseticidas eliminam a interação natural da planta com o solo e o produto, facilitando sua ação. O efeito pode não ser confirmado num experimento com tratamento via solo. Verkerk et al. (1998) constataram isso ao aplicar uma solução de 300 ppm de azadiractina no solo (10 vezes mais o recomendado em aplicação foliar) e também mergulhando as raízes nessa solução. No primeiro caso, não houve efeito inseticida sistêmico sobre os pulgões M. persicae e Brevicoryne brassicae L., enquanto no segundo caso a mortalidade foi de $100 \%$ para as duas espécies de inseto.

O efeito residual do nim sobre $B$. tabaci em plantas de algodão é conhecido tanto em aplicações foliares, como na semente ou no solo. O efeito via foliar foi observado nas concentrações de 0,2 e 2,0\% (Coudriet et al., 1985a). Em experimento sem chance de escolha as plantas de algodão foram tratadas e infestadas com adultos de mosca-branca que permaneceram em oviposição por $24 \mathrm{~h}$, tendo sido avaliada a mortalidade ninfal. O experimento também foi realizado com infestações aos 1 e 7 dias após a aplicação. Outro experimento, em condições de chance de escolha foi conduzido, liberando-se os adultos em plantas com 1, 7 e 14 dias após a aplicação. Nos dois tipos de testes, houve aumento na mortalidade ninfal nos tratamentos com nim. Esse efeito provavelmente é devido à translocação do produto via sistêmica, uma vez que na folha ocorre degradação dos compostos ativos do nim (Saxena et al., 1984).

O efeito via solo e pelas sementes foi observado por Prabhaker et al. (1999). As sementes foram tratadas por $24 \mathrm{~h}$ em $50 \mathrm{ml}$ das seguintes soluções: duas concentrações de Azatin (30 e 60 ppm); 1\% de extrato de sementes de nim; $5 \%$ de uréia e a mistura de extrato de sementes de nim e uréia (1:1). Foi feito o plantio e as plantas com 3 ou 4 folhas verdadeiras foram 
infestadas com adultos de mosca-branca em gaiolas com chance de escolha. Foi avaliado o número de ovos, a porcentagem de eclosão ninfal e o número de adultos que emergiram. Para o tratamento de solo, $10 \mathrm{ml}$ das mesmas soluções foram usadas em $125 \mathrm{~g}$ de solo ao redor do caule. Os adultos foram infestados $48 \mathrm{~h}$ após o tratamento, avaliando-se os mesmos parâmetros. No tratamento de sementes, somente o extrato de sementes de nim a 1\% não afetou o número de ovos. A porcentagem de eclosão foi afetada nos tratamentos com Azatin 60 ppm, extrato de sementes de nim a $1 \%$ e a mistura deste com uréia. A emergência de adultos foi diminuída em todos os casos, mas no tratamento com uréia o efeito foi menor que nos tratamentos com derivados do nim. No tratamento de solo, somente a uréia isoladamente não afetou a biologia do inseto. Em geral, o número de ovos foi menor no tratamento de solo, fato que, segundo os autores, se deveu a maior persistência do extrato de sementes de nim no solo com maior mobilidade das raízes para as folhas, comparado com o tratamento de sementes. A translocação do nim pela planta aumenta a sua persistência por até um mês, o que faz dessa opção uma boa alternativa de controle de insetos vetores como a mosca-branca.

\subsubsection{Efeito de extratos botânicos sobre Bemisia spp.}

Muitos extratos de plantas já foram testados para controle de $B$. tabaci, tendo sido observados efeitos diversos sobre o inseto desde a deterrência para oviposição e alimentação até a mortalidade nas diversas fases do ciclo biológico dessa praga. Dentre as plantas testadas, o nim tem se destacado como uma das mais eficazes. O efeito ovicida foi observado apenas com extratos de plantas da família Meliaceae.

Coudriet et al. (1985a) constataram quase $100 \%$ de inviabilidade

de ovos aplicando o extrato aquoso de sementes de nim a 0,2 e $2 \%$ sobre plantas de algodão, em condições de laboratório. 
Prabhaker et al. (1989) constataram que a fase de ovo é a mais difícil de ser atingida pelo extrato de sementes de nim, porém os níveis de resistência de $B$. tabaci biótipo $B$ ao nim foram mais baixos do que de alguns inseticidas convencionalmente utilizados no controle de mosca-branca.

O óleo de sementes de nim afeta a viabilidade de ovos tanto em aplicações foliares, quanto na semente ou no solo (Prabhaker et al., 1999). O efeito é maior na aplicação foliar (45\%) seguida da aplicação nas sementes (40\%) e no solo (22\%). Hammad et al. (2000) não observaram efeito ovicida de dois produtos comerciais de nim $(0,25$ e $3 \%$ de azadiractina). É possível que em extratos de sementes aquosos ou oleosos estejam presentes outros compostos que tornam esses extratos mais eficientes do que produtos comerciais compostos de azadiractina.

Souza \& Vendramim (2000a) observaram que extratos aquosos de ramos de $T$. pallida e folhas de $M$. azedarach nas concentrações de 1, 2 e $3 \%$ tiveram efeito ovicida sobre o biótipo $B$ em plantas de tomateiro. O primeiro extrato, a $3 \%$, foi mais efetivo. Os mesmos autores compararam esses extratos a 3\% com o extrato aquoso de sementes de nim também a 3\% (Souza \& Vendramim, 2000b). O extrato de ramos de T. pallida teve efeito ovicida superior ao dos outros extratos. Além disso, os autores compararam este efeito em relação a extratos aquosos de diferentes estruturas de $M$. azedarach e de $T$. pallida. Os extratos de folhas e frutos verdes de $M$. azedarach tiveram efeito ovicida semelhante. Os extratos de frutos maduros e de ramos não afetaram a viabilidade dos ovos. Já o extrato de ramos de $T$. pallida foi mais efetivo do que os de folhas e córtex (Souza \& Vendramim, 2001). Os extratos de frutos maduros de $M$. azedarach extraídos em quatro solventes (água, acetona, éter e metanol) também não apresentaram efeito ovicida sobre $B$. tabaci nas concentrações de 2, 20 e 200 mg/ml (Hammad et al., 2000).

A fase ninfal é a mais afetada pelos extratos botânicos e devido à grande sensibilidade dos ínstares iniciais, é provável que numa seleção de 
plantas inseticidas seja mais fácil a identificação de plantas promissoras por meio de testes sobre o primeiro e segundo ínstares.

Coudriet et al. (1985a) constataram o efeito deletério sobre ninfas de B. tabaci, principalmente do primeiro ínstar. Prabhaker et al. (1989) e Hammad et al. (2000) observaram que o primeiro e segundo ínstares ninfais são as fases mais sensíveis ao extrato aquoso de sementes de nim e extratos orgânicos e aquoso de folhas de $M$. azedarach, vindo a seguir os demais ínstares, a fase de "pupa" e a fase de ovo. Segundo Stansly \& Liu (1994) e Liu \& Stansly (1995a e b), um produto comercial à base de azadiractina e outro à base de $N$. gossei também se mostraram mais eficientes sobre os estádios ninfais iniciais. Coudriet et al. (1985a) sugerem que a maior sensibilidade das ninfas de estádios iniciais ao nim seja por sua ação no sistema neuro-endócrino que regula a produção de ecdiesteróides ou como anti-ecdiesteróide. É provável que o nim afete o sistema endócrino desses insetos, pois Natarajan \& Sundaramurthy (1990) observaram que o óleo de nim provocou sintomas de má formação de adultos característicos de disfunções do sistema endócrino dos insetos (Saxena \& Khan, 1985a). Prabhaker et al. (1989), por sua vez, acreditam que o ovo é mais difícil de ser afetado por estar protegido pelo córion, enquanto que a fase de "pupa" é menos sensível do que os primeiros ínstares ninfais devido ao seu maior tamanho exigindo uma quantidade maior de inseticida para afetá-la, ou ainda pela menor penetração dos compostos inseticidas através do tegumento "pupal". A hipótese dos últimos autores é fortalecida pelo fato de eles terem observado a mesma tendência de sensibilidade das fases imaturas a outros inseticidas além do nim.

Natarajan \& Sundaramurthy (1990), avaliando a mortalidade ninfal causada pelo óleo de nim (0,5 e 1\%), constataram que apenas 14,3 e 13,0\% das ninfas chegaram ao estádio adulto, dentre as quais 51,3 e 56,8\%, respectivamente, apresentaram anormalidades, enquanto nas testemunhas (monocotrofós a 0,08\% e água), 84,3 e $94,0 \%$ das ninfas atingiram a fase adulta, com índices de anormalidade de 7,0 e 2,8\%, respectivamente. Dentre as 
anormalidades mais freqüentes, foram observadas emergência incompleta dos adultos dos "pupários" e má formação das asas.

Souza \& Vendramim (2000b) aplicaram extratos aquosos (3\%) de ramos de $T$. pallida, frutos verdes de $M$. azedarach e de sementes de nim somente na fase de ovo e depois sobre ovos e ninfas $B$. tabaci, constatando que a mortalidade ninfal só ocorre com a aplicação direta sobre a ninfa, pois as ninfas que eclodiram de ovos tratados não tiveram sua viabilidade afetada. Os autores também compararam a mortalidade ninfal causada por extratos de diferentes estruturas vegetais de T. pallida e de $M$. azedarach a $3 \%$. Os extratos de frutos verdes de $M$. azedarach e de ramos de $T$. pallida foram os mais eficientes.

Hammad et al. (2000) compararam o efeito deletério sobre ninfas jovens aplicando extratos aquoso, acetônico, etérico e metanólico de folhas de M. azedarach nas concentrações de 2, 20 e $200 \mathrm{mg} / \mathrm{ml}$. Todos os extratos afetaram as ninfas. Em geral, na maior concentração, os extratos orgânicos foram mais eficientes do que o extrato aquoso, sugerindo que os componentes bioativos tenham sido extraídos mais eficientemente com solventes orgânicos. Os extratos metanólicos foram mais eficientes do que os demais extratos.

$\mathrm{O}$ atraso no desenvolvimento das fases imaturas com a aplicação de extrato de sementes de nim (2\%) foi observado por Coudriet et al. (1985a). $\mathrm{Na}$ concentração de $0,2 \%$, esse efeito ocorreu apenas nas ninfas de segundo e terceiro ínstar. Prabhaker et al. (1989) relataram que altas concentrações de inseticidas atrasam o desenvolvimento da fase de ovo. Outros autores não têm observado qualquer efeito de extratos de meliáceas sobre a duração do desenvolvimento das fases imaturas de B. tabaci (Prabhaker et al. 1999 e Souza \& Vendramim, 2000a e b, 2001).

Extratos de várias espécies vegetais tiveram efeito comprovado na sobrevivência de adultos de mosca-branca.

Prabhaker et al. (1989) observaram que os ovos são mais afetados pelo nim do que os adultos, mas que, de modo geral, estas duas fases são 
difíceis de serem controladas. Os autores também demonstraram que os níveis de resistência aos inseticidas são maiores nos adultos do que em qualquer outra fase do inseto, o que evidencia que esta fase sofre maior pressão de seleção. Com extrato de N. gossei, Stansly \& Liu (1994) também constataram que a DL50 foi maior para a fase adulta em relação a qualquer ínstar ninfal do biótipo B. Kays et al. (1994) testaram compostos de ésteres de açúcar isolados de petúnia sobre a fase ninfal e adulta do biótipo $B$ e também verificaram maior mortalidade na fase ninfal em comparação com a fase adulta. Segundo os autores, esses compostos são obtidos dos tricomas das superfície das folhas de petúnia e de espécies de Nicotiana, sendo que a concentração difere muito, qualitativa e quantitativamente, entre as cultivares de petúnia e dentro do gênero Nicotiana. Assim, é possível que sejam identificados compostos altamente tóxicos entre as várias espécies e cultivares existentes nesses dois grupos de plantas. Essas substâncias parecem estar envolvidas na resistência de tomate, batata e fumo a afídeos (Goffreda et al., 1989 e King et al., 1987). Em aplicações no campo, houve grande redução na população de adultos e na quantidade de ovos, o que pode ser devido à deterrência para alimentação e oviposição ou pela mortalidade de adultos.

Embora a fase adulta seja difícil de ser controlada, Natarajan \& Suandaramurthy (1990) constataram a má formação de adultos mesmo após a aplicação de óleo de nim a 0,5 e 1\% sobre as ninfas de terceiro ínstar. Por outro lado, Cubillo et al. (1994) não constataram qualquer mortalidade nos adultos com a aplicação de três produtos comerciais à base de azadiractina.

Liu \& Stansly (1995a) obtiveram baixo nível de controle de adultos de $B$. tabaci biótipo $B$, em plantas de tomate, em laboratório, usando um produto comercial à base da solanácea Nicotiana gossei (0,5, 1,0 e 2,0 g i.a./L).

O extrato aquoso de folhas e frutos de $M$. azedarach (20\%) também afeta a sobrevivência dos adultos de mosca-branca (Nardo et al., 1997). Gómez et al. (1997a e b) identificaram diversas plantas que afetam a sobrevivência de adultos de mosca-branca. As causas não são conhecidas, 
mas são atribuídas à presença de metabólitos secundários atuando diretamente como tóxicos ou, ainda como deterrentes alimentares que, por conseguinte, levam os adultos à morte por inanição.

Cubillo et al. (1997) compararam o efeito inseticida sobre os adultos de mosca-branca com extratos aquosos e metanólicos de Quassia amara em diferentes concentrações ( 5 a $50 \%$, v/v). Todos os tratamentos tiveram efeito sobre o inseto, mas os extratos metanólicos foram os mais efetivos.

Em nenhum dos trabalhos analisados houve mortalidade expressiva de adultos como se constata com ninfas, confirmando a dificuldade de se controlar essa fase do inseto.

A deterrência provocada por extratos durante a alimentação e oviposição de mosca-branca é um dos parâmetros mais utilizados na seleção de extratos promissores no controle da praga, mas os resultados não são expressivos considerando que se trata de um inseto transmissor de fitovírus (Cubillo et al., 1994 e 1999 e Gómez et al., 1997a e b).

Ao contrário do efeito sobre ninfas em que o nim é comprovadamente eficiente, a repelência nem sempre é observada. Coudriet et al. (1985a), testando um extrato aquoso de sementes de nim e Cubillo et al. (1994), testando um produto comercial à base de nim, por exemplo, encontraram repelência de adultos o que acarretou menor oviposição. Por outro lado, Gómez et al. (1997a) e Cubillo et al. (1999) não observaram efeito repelente sobre a mosca-branca utilizando produtos comerciais à base de nim. Cubillo et al. (1994) sugerem que a maior atividade repelente com extratos aquosos de sementes de nim em relação a outros produtos derivados dessa planta seja por alguma influência do método de extração, ou ainda que nos extratos aquosos se encontram substâncias que cumprem essa função, mas que não estão presentes em produtos comerciais purificados. 
Os extratos orgânicos e aquosos de $M$. azedarach também foram comprovados pelo seu efeito deterrente alimentar sobre B. tabaci (Hammad et al., 2000 e Nardo et al., 1990, 1997).

Larew \& Locke (1990) observaram que adultos de Trialeurodes vaporariorum (Westwood) pousavam em plantas tratadas com um óleo comercial e imediatamente saíam das plantas tratadas. Dessa forma, é possível que existam sensilos químicos nos tarsos desses insetos que thes permite distinguir a superfície foliar antes mesmo de iniciar a alimentação. É necessário conhecer as funções dos sensilos labiais presentes nas moscas-brancas (Walker \& Gordh, 1989) para que os resultados com deterrência sejam melhor compreendidos.

É difícil separar deterrência para alimentação de deterrência para oviposição, pois ambos os comportamentos estão intimamente relacionados. A maior parte da oviposição de $B$. tabaci ocorre dentro do primeiro minuto de início da penetração estiletar (Walker \& Perring, 1994). Como este tempo é insuficiente para que os estiletes alcancem o floema é provável que esses insetos façam uma seleção do local para oviposição antes do alcance do floema; entretanto, os autores não puderam confirmar essa informação porque os insetos foram testados sobre a mesma planta em que foram criados e então pode ter ocorrido uma pré-adaptação.

Nem sempre a diminuição na população de insetos vetores é suficiente para diminuir a ocorrência de doenças na cultura. Asiático \& Zoebisch (1992) constataram diminuição na população de moscas-brancas pela aplicação de extrato aquoso de sementes de nim (60 g/L de água) mas a ocorrência de virose associada à mosca-branca foi de 100\%. Por outro lado, Sabillón \& Bustamante (1995) observaram que extratos aquosos de sementes de nim e de mamona, $R$. communis (ambos a $50 \mathrm{~g} / \mathrm{L}$ de água) diminuíram a ocorrência de viroses em tomateiro.

O efeito de extratos sobre a transmissão de fitovírus é afetado pela relação do vírus com a mosca-branca e também pelas condições do ambiente (casa de vegetação ou campo). Por exemplo, Nardo (1989) constatou 
que, em condições de casa de vegetação, o extrato aquoso de folhas de $M$. azedarach ( $1 \mathrm{~g} / 5 \mathrm{ml}$ de água) provocou diminuição drástica na aquisição e inoculação do vírus do mosaico dourado do feijoeiro (VMDF), de relação circulativa na mosca-branca, porém Nardo et al. (1997) relataram que a mesma planta não foi eficiente na prevenção de um vírus não-circulativo. Nardo \& Costa (1990) observaram efeito menor sobre a transmissão do VMDF com o extrato aquoso de folhas e frutos de M. azedarach em partes iguais ( $200 \mathrm{~g} / \mathrm{L}$ de água), quando o experimento foi conduzido no campo. A adição de óleo vegetal 1\% ao extrato aumentou a eficiência deste.

Vicente et al. (1977) acreditam que a ação dos extratos é específica, podendo agir numa determinada relação inseto-planta e não exercer qualquer efeito em outras relações. Para Nardo \& Costa (1997), a interferência de $M$. azedarach na transmissão de vírus por mosca-branca é específica para esse inseto, pois segundo suas observações, o pulgão $M$. persicae não é afetado no seu processo de transmissão de vírus circulativo ou não-circulativo.

O efeito inibidor de fitovírus por extratos parece ser mais evidente em inoculações mecânicas do que em inoculações por vetores sugerindo que os extratos induzem resistência na planta adiando ou minimizando o aparecimento de sintomas de fitoviroses (Alexandre et al.,1987; Chessin, 1983 e Hunter \& Ullman, 1992).

É provável que o nim afete a eficiência de transmissão de vírus fitopatogênico por esse inseto em razão da deterrência alimentar (Coudriet et al., 1985a; Cubillo et al., 1994, 1997, 1999 e Gómez et al. 1997a e b). Segundo Markham et al. (1995), pela relação de circulação persistente no vetor, o período de aquisição de geminivírus por B. tabaci é de 30 a 60 min e o período de transmissão de 5 a $15 \mathrm{~min}$. Assim, um produto deterrente de alimentação pode diminuir a transmissão do geminivírus mesmo ocorrendo a picada de prova. 


\subsubsection{Metodologia de extração de compostos inseticidas}

O método de preparo de extratos vegetais com o objetivo de verificar sua ação inseticida é de grande importância. As plantas inseticidas contêm uma variedade de compostos ativos que, pelas suas características químicas individuais, exigem métodos apropriados para extração.

Ferri (1996) fez uma revisão sobre os métodos gerais de extração de compostos de plantas, visando orientar pesquisadores a respeito dos pontos básicos no processo de extração de compostos naturais. Os cuidados devem se iniciar na coleta do material. Segundo o autor, o material botânico deve ser identificado por um taxonomista. Deve-se fazer uma limpeza para retirada de partes de outras plantas ou microrganismos contaminantes, seguido da anotação de dados de identificação (nome comum, local, coletor e data). Se possível, o material deve ser imerso em álcool etílico sob ebulição, logo após a coleta, prevenindo oxidações e hidrólise enzimática. Materiais que apresentem elevado teor de água, como folhas, flores e frutos, podem ser acondicionados em sacos plásticos, à temperatura inferior a $10^{\circ} \mathrm{C}$, a fim de minimizar a deterioração.

Segundo Matos (1988), outra alternativa é a secagem imediata do material à sombra e em local arejado, sendo necessária, em muitos casos, uma fragmentação prévia. Então, o material é seco em estufa, entre $40^{\circ}$ e $60^{\circ} \mathrm{C}$, com ventilação forçada, sob condições controladas para evitar rearranjos químicos. Antes da extração, tritura-se o material em moinho mecânico e, nessas condições, o material poderá ser armazenado por bastante tempo em latas, caixas ou em sacos plásticos. Recomenda-se que o armazenamento seja feito em prateleiras de madeiras suspensas, em local arejado, para evitar contaminação por microrganismos ou mesmo ataque de insetos e roedores.

$\mathrm{Na}$ extração, utilizam-se no mínimo três vezes mais solvente do que o peso do material. Com material clorofilado, é necessário remover a clorofila e outros corantes vegetais que dificultam o fracionamento químico ou cromatográfico. Uma técnica padrão para remoção de corantes vegetais foi 
descrita em detalhes por Queiroz Paulo (1983).

O procedimento padrão de extração para obtenção de extratos orgânicos é feito com solventes de polaridade crescente, em sistemas contínuos do tipo Soxhlet. Entretanto, é importante ressaltar que o processo de extração a frio por percolação, apesar de requerer mais solvente, apresenta menor risco de reações químicas, em comparação ao sistema Soxhlet que trabalha em altas temperaturas (Ferri, 1996).

É comum numa extração de compostos vegetais serem obtidos três extratos, utilizando-se como principais solventes: hexano, clorofórmio ou éter (para compostos apolares) e etanol ou metanol (para compostos mais polares). Algumas vezes, se obtém primeiro um extrato alcoólico exaustivo (etanol 95\%) que, após a evaporação do solvente, é submetido à extração com os solventes apolares, mas quando se pretende retirar inicialmente os lipídeos inicia-se a extração com um solvente apolar, passando para um polar (Ferri, 1996; Matos, 1988).

Em geral, extratos altamente apolares ou altamente polares têm menor atividade em comparação com extratos de polaridade intermediária.

Ascher et al. (1984) compararam o efeito de vários extratos de sementes de nim com solventes de diferentes polaridade sobre a biologia de Spodoptera littoralis (Boisduval) e constataram que os extratos mais tóxicos foram aqueles obtidos com os solventes mais polares (constante dielétrica $>20$ ): água $(78,5)$, metanol $(32,6)$, etanol $(24,3)$ e acetona $(20,7)$.

Saito et al. (1989) compararam o efeito inseticida de extratos de diferentes estruturas vegetais de 30 espécies com extração em solventes de polaridade crescente sobre alguns insetos. Foram pesados $50 \mathrm{~g}$ de pó de extrato e inicialmente extraídos com $200 \mathrm{ml}$ de hexano por maceração a frio, seguida de extrações sucessivas até alcançar o volume de $500 \mathrm{ml}$. Os pós foram novamente extraídos com etanol, também por maceração, obtendo-se $500 \mathrm{ml}$ de extrato etanólico, empregando-se técnicas semelhantes ao caso anterior. O pó vegetal novamente seco foi extraído com solução de álcool-água 
a aproximadamente $30^{\circ} \mathrm{GL}$, obtendo-se os $500 \mathrm{ml}$ de forma semelhante. $\mathrm{O}$ número total de extratos obtidos nessa etapa foi de 179. Os extratos mais promissores foram novamente extraídos com etanol, por percolação, obtendose extratos mais concentrados que os primeiros, na proporção planta-extrato igual a 1:2. Nessa etapa, foram separados 28 extratos. Numa última etapa foram preparados extratos acetônicos em Soxhlet na proporção 1:2 (planta: extrato). Os efeitos variaram em função das espécies de plantas e de insetos, mas em todos os casos a maior atividade inseticida foi obtida com os solventes de polaridade intermediária (etanólicos, acetônicos e hidroalcoólicos) em comparação com os hexânicos.

Cubillo et al. (1997) observaram que extratos metanólicos de Quassia amara foram mais efetivos contra B. tabaci do que extratos aquosos. Foram feitas duas extrações. Na primeira, aquosa, 1,3 kg de ramos moídos com partículas de $3 \mathrm{~mm}$ foram misturados a $1,3 \mathrm{~L}$ de água destilada a $50^{\circ} \mathrm{C}$, sendo 0 material deixado em repouso por $4 \mathrm{~h}$ e, então, filtrado. Esse procedimento foi feito três vezes. Na segunda, metanólica, com a mesma quantidade de material da extração anterior foi utilizado 1,3 L de metanol 95\% por $24 \mathrm{~h}$ três vezes seguidas. As duas soluções foram colocadas em rotaevaporador a $40^{\circ} \mathrm{C}$ (aquoso) ou $30^{\circ} \mathrm{C}$ (metanólico) para reduzir o volume até $250 \mathrm{ml}$. A concentração de sólidos total do extrato cru metanólico foi de 11,3\%. Para 0 extrato aquoso, não foi possível se fazer essa determinação.

Roel et al. (2000) compararam o efeito de dois extratos de ramos e folhas de $T$. pallida, um acetônico e um metanólico, sobre lagartas de $S$. frugiperda. O extrato acetônico provocou maior mortalidade larval do que o metanólico. A seguir foi feita uma partição do extrato acetônico com os solventes hexano e acetato de etila. $O$ extrato mais efetivo foi a acetona de polaridade 5,4 , seguida do metanol $(6,6)$, do acetato de etila $(4,3)$ e do hexano $(0,0)$.

Singh et al. (1988) e Cubillo et al. (1999), entretanto, obtiveram melhores resultados com extratos botânicos extraídos com solventes apolares. 
Singh et al. (1988) prepararam extratos aquosos, etanólicos e hexânicos de sementes de nim e os testaram sobre o pulgão Lipaphis erysimi Kalt. O pó vegetal $(50 \mathrm{~g})$ foi mantido durante $3 \mathrm{~h}$ em aparelho de ultra-som, e submetido à filtração em papel de filtro Whatman n.1. O remanescente da filtração foi novamente submetido ao ultra-som por uma hora e filtrado. Ambos foram misturados e a água evaporada. O extrato etanólico recebeu o mesmo procedimento. O extrato hexânico foi obtido de $100 \mathrm{~g}$ de pó vegetal. Foram feitas sucessivas extrações com $200 \mathrm{ml}$ de hexano por vez até que todo o óleo fosse extraído e então as frações foram misturadas e o solvente evaporado. $\mathrm{O}$ maior efeito foi obtido com o extrato hexânico, talvez porque o material vegetal inicial (100 g) tenha sido o dobro do utilizado nos outros extratos (50 g).

Cubillo et al. (1999) prepararam extratos de raiz de Echinacea purpurea (Compositae) em partições sucessivas com solventes de polaridade crescente: éter de petróleo, diclorometano, acetato de etila e água e testaram sua atratividade sobre adultos de $B$. tabaci. Também foi extraído o material com etanol separadamente sem as partições anteriores em solventes de maior polaridade. O extrato a partir de éter de petróleo (mais apolar), foi mais repelente para os adultos, enquanto os demais não diferiram entre si. A repelência para oviposição foi maior no extrato com diclorometano, sendo que os demais não diferiram entre si, o que sugere que, nessa planta, os compostos que causam a repelência em mosca-branca sejam apolares.

Por ocasião do isolamento de compostos hidrossolúveis de plantas, é conveniente a remoção dos lipídeos, com extração prévia em álcool etílico seguida de sucessivas extrações com éter de petróleo antes da sua concentração em evaporador rotativo. $\mathrm{Na}$ extração de compostos polares de plantas ricas em taninos, recomenda-se uma extração prévia com hexano (para desengordurar o material), seguindo-se de extração com éter etílico, para extração dos compostos polares desejados, mas livres de taninos. Uma extração final com álcool etílico retiraria os compostos polares não extraídos pelo éter etílico, juntamente com os taninos (Matos, 1988). Mikolajczak \& Reed 
(1987), por exemplo, submeteram sementes de nim à extração prévia em nhexano e, após a secagem, os compostos foram extraídos em etanol 95\%. O solvente foi removido por meio de rotaevaporação a $40^{\circ} \mathrm{C}$ e o resíduo foi armazenado em freezer. Por ocasião da utilização, o produto foi novamente dissolvido em etanol na proporção de $5 \%(\mathrm{p} / \mathrm{v})$ para se espalhar no substrato, aguardando-se 5 min para secagem e teste sobre lagartas de $S$. frugiperda.

Govindachari et al. (2000) também fizeram extração de óleo de sementes de nim com solventes de polaridade crescente. O óleo de nim obtido foi dissolvido em hexano (1,5 L) e fracionado com metanol 95\% (3 x $500 \mathrm{ml})$. $\mathrm{O}$ resíduo metanólico foi concentrado em vácuo para produzir o resíduo chamado de E1 (57 g). E1 foi submetido ao HPLC (cromatógrafo líquido de alta precisão). Para cada volta, $5 \mathrm{~g}$ de E1 foram dissolvidas em $20 \mathrm{ml}$ de metanol, seguido de filtração através de filtro Milipore $0,25 \mu$, sendo o filtrado submetido ao HPLC. $O$ efluente escoado foi de $30 \mathrm{ml} / \mathrm{min}$ por volta completa. Durante os primeiros 60 min foi usado metanol: água na proporção de 60:40; depois até o final a proporção foi de 70:30. A fração eluída de 10 até 50 min (e-2A) e 51 até 105 min (E-2S) foi coletada e concentrada em vácuo para produzir 12,3 g e 33,6 g, respectivamente. Quatro gramas do E-2S foram novamente submetidas a HPLC nas mesmas condições iniciais e frações de 61-85 min foram coletadas e concentradas em vácuo para produzir $2,2 \mathrm{~g}$ de E-2S-S. Os extratos foram aplicados na quantidade de $1 \mu \mathrm{g} / \mathrm{cm}^{2}$ de folha.

Considerando que solventes de polaridade intermediária podem extrair compostos bioativos mais eficientemente, alguns autores já testam extratos botânicos com solventes nessa especificação, dispensando extratos apolares (Cubillo et al., 1999; Gómez et al., 1997b e Neal et al., 1994).

Gómez et al. (1997b) prepararam 27 extratos vegetais para se avaliar o efeito repelente sobre $B$. tabaci. Os materiais foram secos a $40^{\circ} \mathrm{C}$ e $100 \mathrm{~g}$ do material foram moídas e misturadas com etanol $70 \%$ por $24 \mathrm{~h}$. O material foi filtrado e novamente passado em etanol $70 \%$ por $24 \mathrm{~h}$. A filtragem foi feita através de papel Whatman n.4 ou de um pedaço de algodão, para 
aumentar o rendimento da extração. O resíduo foi concentrado através de rotaevaporação a $40^{\circ} \mathrm{C}$ e posteriormente liofilizado. Nenhum dos extratos provocou repelência ao pouso ou deterrência à oviposição, mas vários provocaram mortalidade de adultos.

Cubillo et al. (1999) testaram a repelência de vários extratos vegetais e inseticidas sobre $B$. tabaci. No preparo dos extratos, secaram-se aproximadamente $2,5 \mathrm{~kg}$ de cada planta a $50^{\circ} \mathrm{C}$ por 4 dias. O material resultante foi moído, acrescentando-se uma mistura de 80:20 (etanol:água) por 4 dias. A solução foi filtrada e o extrato cru foi concentrado por meio de rotaevaporação a $45^{\circ} \mathrm{C}$. Em todos os casos, se determinou a concentração dos solutos totais (por $\mathrm{ml}$ ) por meio da eliminação do solvente. Assim, todos os extratos foram usados na concentração de 100 ppm (0,1 g/L) com aproximadamente $0,1 \%$ de ingrediente ativo.

O conhecimento sobre os compostos químicos responsáveis pela atividade inseticida de $T$. pallida ainda é escasso, mas acredita-se que compostos do grupo de terpenóides que incluem a hirtina e as triquilinas estejam envolvidos (Simmonds et al., 2001 e Xie et al., 1994).

Atualmente, sabe-se que extratos de ramos e folhas de T. pallida têm efeito inseticida sobre a mosca-branca, mas não foi identificado nenhum grupo de composto químico responsável por esse efeito (Souza \& Vendramim, 2000a e b, 2001).

Após a obtenção do extrato orgânico outro problema precisa ser solucionado para seu uso nos bioensaios com insetos. Quando o extrato for misturado à dieta artificial, ele deve ser diluído em água ou um solvente para facilitar a homogeneização da mistura. É importante que na utilização de um solvente orgânico, seja aguardada a evaporação antes de a dieta ser oferecida ao inseto. Por outro lado, quando se pretende fazer aplicação tópica, foliar ou líquida no solo, o resíduo precisa ser diluído em água ou em um solvente que não seja tóxico à planta e ao inseto.

A diluição é mais fácil quanto mais afinidade química tem o extrato 
com a água. Extratos etanólicos, metanólicos ou hidroalcoólicos podem ser dissolvidos diretamente na água (Cubillo et al., 1994, 1997 e 1999; Gómez et al. 1997 e Hammad et al., 2000).

Extratos mais apolares têm maior dificuldade em ser diluído diretamente na água e, nesse caso, faz-se uma diluição com um solvente semelhante a ambos (extrato e água) para se fazer uma aproximação do extrato com a água, facilitando a diluição. A azadiractina pura extraída de sementes de nim pode ser dissolvida primeiro em etanol para sua posterior diluição na água (Dorn et al., 1986 e Nisbet et al., 1993 e 1996).

Numa pesquisa em que são comparados extratos orgânicos de diferentes polaridades, é importante que se use apenas um solvente preliminar para todos os extratos o que possibilita o uso de apenas um tratamento como testemunha (água + solvente preliminar). A acetona é indicada para esse uso pela capacidade de dissolver extratos obtidos com solventes de diferentes polaridades, desde acetônicos até hexânicos, além do óleo de sementes de nim e limonóides isolados de várias meliáceas (Abraham \& Ambika, 1979; Govindachari et al., 2000; Griffiths et al., 1978; Huang et al., 1995; Mikolajczak \& Reed, 1987; Roel et al.,2000; Saito et al., 1989; Saxena et al., 1993 e Saxena \& Khan, 1985b). 


\section{MATERIAL E MÉTODOS}

Os experimentos foram realizados no Laboratório de Plantas Inseticidas do Departamento de Entomologia, Fitopatologia e Zoologia Agrícola da ESALQ/USP, em Piracicaba/SP, com o objetivo de avaliar o efeito e o modo de ação de extratos das meliáceas Azadirachta indica A. Juss (nim) e Trichilia pallida (Swartz) sobre a mosca-branca Bemisia tabaci (Genn., 1889) biótipo B.

\subsection{Obtenção e criação dos insetos}

A colônia de mosca-branca foi obtida de uma criação do Setor de Entomologia do Centro de Fitossanidade do Instituto Agronômico de Campinas (IAC), identificada como biótipo $B$ de B. tabaci. A criação foi mantida em uma casa de vegetação (com aproximadamente $2,5 \mathrm{~m}^{2}$ ), fechada com tela fina e coberta com vidro. Como hospedeiro, foram utilizadas plantas de amendoimbravo (Euphorbia heterophila) cultivadas em vasos plásticos. A cada 20 dias, novas plantas eram introduzidas para substituir aquelas em que tinha ocorrido emergência dos adultos. Essas plantas eram descartadas quando essa emergência se completava. 


\subsection{Obtenção do material vegetal e dos extratos}

Para obtenção das plantas de tomateiro (cv. Santa Clara) utilizadas nos diversos experimentos, a semeadura era feita em bandejas de isopor (128 células). Após cerca de 20 dias, as mudas eram transplantadas para sacos plásticos com capacidade para $5 \mathrm{~L}$ de substrato.

Os ramos e folhas de $T$. pallida foram coletados em área de mata da ESALQ/USP, enquanto as sementes de nim foram obtidas junto à empresa Nim do Brasil Ltda., em Campinas, SP.

Para preparo dos extratos aquosos, os ramos de $T$. pallida, bem como as sementes de nim, após secagem em estufa com circulação de ar $\left(a 40^{\circ} \mathrm{C}\right.$, por cerca de 48h), foram triturados em moinho, obtendo-se então os pós vegetais. Estes foram adicionados (separadamente por espécie) à água destilada, na proporção de $10 \mathrm{~g}$ por $100 \mathrm{ml}$. Essas misturas foram mantidas em local escuro por 24h para extração dos compostos hidrossolúveis. Após esse período, o material foi filtrado, obtendo-se os extratos a 10\%, a partir dos quais foram obtidas, por diluição, as concentrações desejadas.

Além dos extratos aquosos, foram preparados quatro extratos orgânicos (metanólico, etanólico, clorofórmico e hexânico). Esses extratos foram obtidos diluindo-se $5 \mathrm{~g}$ de pó vegetal em $100 \mathrm{ml}$ de cada um dos solventes. As suspensões (solvente + pó) foram submetidas à extração em ultra-som por 40 min. Após o processo de extração, as suspensões foram filtradas com auxílio de vácuo, através de funil de Büchner forrado ao fundo com papel de filtro, para um kitassato; os solventes foram evaporados/concentrados com o auxílio de um evaporador rotativo à vácuo (rotavapor) obtendo-se, então os extratos. Por ocasião da utilização, os extratos foram diluídos em $5 \mathrm{ml}$ de acetona e acrescentada água até o volume de $100 \mathrm{ml}$ para obtenção da solução estoque a ser diluída conforme a concentração utilizada em cada experimento.

Em todas as testemunhas, também utilizou-se água destilada. 


\subsection{Determinação das concentrações adequadas dos extratos a serem utilizadas nos experimentos.}

O objetivo destes experimentos foi determinar uma concentração de extrato de sementes de nim que matasse cerca de $70 \%$ das ninfas de $B$. tabaci, para ser possível comparar o referido extrato com outros que viessem apresentar maior ou menor eficiência.

\subsubsection{Ação translaminar}

\subsubsection{Experimento 1 (laboratório)}

Para obtenção dos ovos, as plantas de tomateiro com cerca de 30 dias de idade tiveram suas folhas do terço superior retiradas. Os pecíolos foram introduzidos num pedaço de canudo de refrigerante, mergulhado em um tubo de vidro $(2,5 \times 8,5 \mathrm{~cm})$, com água e tampado com filme de PVC transparente. Para infestação, foram utilizadas gaiolas de acrílico, no interior das quais foram colocadas 12 folhas de tomateiro. Foram utilizadas cinco gaiolas e liberados cerca de 250 adultos por gaiola, os quais foram mantidos por 24h para oviposição. Após esse período, foram retirados os adultos, sendo as folhas mantidas no laboratório. Após nove dias, quando as ninfas de primeiro ínstar já estavam fixas, foi feita a sua contagem na face abaxial dos folíolos. Nesse dia, foram então aplicados os extratos de sementes de nim (1, 5 e 10\%) e a água (testemunha) na face adaxial dos folíolos. Uma semana após o tratamento, foi avaliada a mortalidade ninfal. As ninfas foram consideradas mortas quando apresentavam tamanho pequeno (cerca de 0,25 X 0,15 mm) e formato elíptico semelhantes ao de ninfas de primeiro ínstar conforme descrito por Eichelkraut \& Cardona (1989) e Patel et al. (1992). Cada repetição correspondeu a um folíolo.

O experimento seguiu o delineamento inteiramente casualizado com quatro tratamentos (três concentrações do extrato: 1, 5 e 10\% e 
testemunha) e nove repetições.

Considerando-se que, em condições de laboratório, houve amarelecimento e desenvolvimento de fungos na maioria das folhas de tomateiro, optou-se por conduzir os experimentos seguintes em casa de vegetação.

\subsubsection{Experimento 2 (casa-de-vegetação)}

Para obtenção dos ovos de mosca-branca, foi utilizada uma gaiola cilíndrica com cerca de $15 \mathrm{~cm}$ (confeccionada com tecido de voil) que podia ser aberta e fechada por um barbante em ambas as extremidades envolvendo um folíolo. Foram mantidas duas gaiolas por planta. Em cada gaiola, foram mantidos cerca de 20 adultos da mosca-branca, durante 12h, para a oviposição. Após nove dias, quando as ninfas de primeiro ínstar já estavam fixas, foi feita a sua contagem na face abaxial dos folíolos. Nesse dia, foram então aplicados os extratos de sementes de nim $(0,5 ; 1$ e $5 \%)$ e a água (testemunha) na face adaxial dos folíolos. Uma semana após o tratamento, foi avaliada a mortalidade ninfal, observando-se os mesmos critérios citados no item anterior.

O experimento foi conduzido por duas vezes e seguiu o delineamento inteiramente casualizado com quatro tratamentos (três concentrações do extrato: 0,5; 1 e 5\% e testemunha) e seis repetições, sendo que cada repetição correspondeu à média de dois folíolos por planta.

\subsubsection{Ação sistêmica}

Todos os experimentos foram conduzidos em casa-de-vegetação e em todos eles, a mortalidade ninfal foi avaliada conforme os critérios citados no item 3.3.1.1. 


\subsubsection{Experimento 1}

A obtenção dos ovos, a contagem de ninfas e a avaliação da mortalidade ninfal foram feitas conforme o item 3.3.1.2. As mudas de tomateiro infestadas com ninfas de mosca-branca foram transplantadas para novos sacos plásticos contendo $300 \mathrm{~g}$ de solo seco. Foram aplicados $50 \mathrm{ml}$ de cada uma das suspensões do extrato de sementes de nim (1, 5 e 10\%) e água (testemunha) sobre o solo seco, na base de cada planta. Foi avaliada a mortalidade de ninfas uma semana após a aplicação dos extratos, sendo que nesse período cada planta foi irrigada duas vezes com $30 \mathrm{ml}$ de água.

O experimento seguiu o delineamento inteiramente casualizado com quatro tratamentos (três concentrações do extrato: 1, 5 e 10\% e testemunha) e seis repetições, sendo que cada repetição correspondeu à média de dois folíolos por planta.

\subsubsection{Experimento 2}

O experimento foi conduzido conforme $\mathrm{o}$ item anterior, exceto pela aplicação de apenas $30 \mathrm{ml}$ das concentrações de 0,5; 1 e 5\% de extrato de sementes de nim e de água ( testemunha) por planta.

\subsubsection{Experimento 3}

Embora a concentração de $0,5 \%$, utilizada no experimento anterior, tenha se mostrado adequada para ser utilizada nas etapas seguintes, foi conduzido um novo experimento com os mesmos procedimentos e concentrações, diminuindo-se, entretanto, o volume aplicado para $20 \mathrm{ml}$, visando o gasto de menor quantidade de extrato.

\subsubsection{Ação de contato}


Todos os experimentos foram conduzidos em casa-de-vegetação.

\subsubsection{Experimento 1}

A obtenção dos ovos foi feita conforme o item 3.3.1.2. Quando a maioria das ninfas apresentava as características de terceiro ínstar ( Eichelkraut \& Cardona, 1989 e Patel et al., 1992), foram marcadas em torno de 20 ninfas vivas por folíolo em dois folíolos por planta. As ninfas foram consideradas vivas observando-se o estágio de desenvolvimento em que se encontravam. A marcação foi feita com um ponto ou círculo em torno da ninfa selecionada com cola colorida solúvel em água. No dia seguinte, foi aplicado $0,2 \mu \mathrm{l}$ de cada extrato de sementes de nim $(0,5 ; 1$ e 5\%) e de água sobre cada ninfa, de modo a cobri-la completamente. A concentração de $10 \%$ foi substituída por $0,5 \%$, em virtude da mortalidade quase total na maior concentração nos experimentos anteriores. Após o tempo necessário para a emergência dos adultos, foram contados os casulos "pupais" vazios com orifício de saída característicos de adultos de mosca-branca, o que indicava que o inseto tinha completado o desenvolvimento. Esse número foi subtraído do numero inicial de ninfas em cada repetição para cálculo da mortalidade ninfal.

O experimento seguiu o delineamento inteiramente casualizado com quatro tratamentos (concentrações do extrato: 0,5; 1 e 5\%, e testemunha) e seis repetições, sendo que cada repetição correspondeu à média de dois folíolos por planta.

\subsubsection{Experimento 2}

Foram repetidos os mesmos procedimentos do item anterior, exceto que as concentrações utilizadas foram de 0,1; 0,3 e 0,5\%. 


\subsection{Avaliação da atividade de extratos orgânicos de T. pallida}

Nesta etapa, o objetivo foi comparar quatro extratos orgânicos de T. pallida, o extrato aquoso dessa espécie e o extrato aquoso de sementes de nim para selecionar o extrato orgânico mais eficiente a ser testado quanto à atividade inseticida pelas vias translaminar, sistêmica e de contato.

Foram conduzidos dois experimentos com oito tratamentos: quatro extratos orgânicos de ramos de T. pallida (metanólico, etanólico, clorofórmico e hexânico), extrato aquoso dessa espécie e de sementes de nim e duas testemunhas, água e água + acetona (5\%).

O preparo dos extratos seguiu a mesma metodologia citada no item 3.2 para os extratos orgânicos.

A infestação de adultos de mosca-branca, obtenção e contagem das ninfas de primeiro ínstar e avaliação da mortalidade ninfal foi feita como citado no item 3.3.1.2. Para aplicação dos tratamentos, folíolos de tomateiro com ninfas foram imersos por dois segundos nos diferentes extratos.

Os experimentos seguiram 0 delineamento inteiramente casualizado com oito tratamentos e quatro repetições, sendo que cada repetição correspondeu à média de dois folíolos por planta. 


\subsection{Avaliação do efeito inseticida de extratos clorofórmico e aquoso de $T$.} pallida e aquoso de sementes de nim

Após a seleção da concentração adequada do extrato a ser utilizada para cada tipo de experimento, bem como do extrato orgânico mais eficiente contra a praga, vários experimentos foram conduzidos para avaliação do efeito inseticida deste extrato orgânico em comparação com extratos aquosos de ramos de $T$. pallida e de sementes de nim, procurando-se identificar a ocorrência do efeito inseticida pelas diferentes vias.

A metodologia utilizada para se avaliar os efeitos translaminar, sistêmico e de contato foi a mesma descrita nos itens 3.3.1, 3.3.2 e 3.3.3, utilizando-se as concentrações de $1 ; 0,5(20 \mathrm{ml})$ e $0,3 \%$, respectivamente. Os tratamentos foram o extrato clorofórmico, o extrato aquoso de ramos de $T$. pallida, o extrato aquoso de sementes de nim e a testemunha (água). A testemunha com acetona foi desnecessária nesta fase porque constatou-se na fase anterior que este solvente não afeta o inseto.

Cada uma das três etapas (translaminar, sistêmica e de contato) foram conduzidas duas vezes. 


\subsection{Avaliação do efeito ovicida de extratos aquosos e orgânicos de meliáceas}

\subsubsection{Influência da idade do ovo no efeito ovicida do extrato aquoso de sementes de nim}

Neste experimento, cerca de 10 fêmeas de mosca-branca foram mantidas em caixas de acrílico $(6 \times 2,5 \mathrm{~cm})$, as quais tiveram sua tampa perfurada num diâmetro de $2,5 \mathrm{~cm}$. Nessa área livre, em cada caixa foi fixado um folíolo de tomateiro da cv. Santa Clara com a face abaxial voltada para dentro da caixa, no interior da qual as fêmeas foram mantidas, por 24h, para oviposição (Fig.1). Em cada área foliar contendo os ovos, foi aplicado o extrato aquoso de sementes de nim a 3\% ou água (testemunha) às 24,96 e 120h após o início do experimento.

Foram utilizados quatro tratamentos com oito repetições em disposição inteiramente casualizada, sendo que cada repetição correspondeu à média de duas gaiolas.

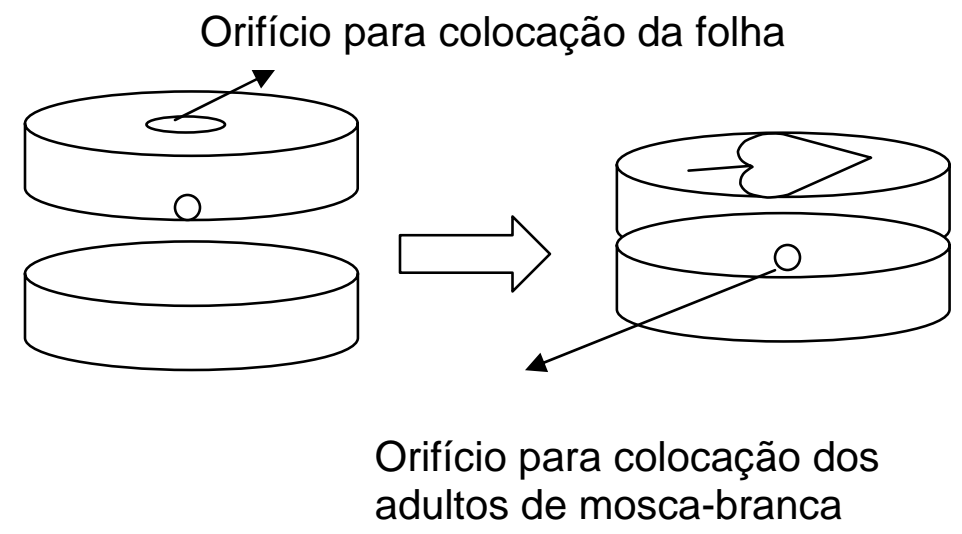

Figura 1- Gaiola utilizada no experimento com ovos de mosca-branca 


\subsubsection{Efeito ovicida de extratos aquosos e orgânico de meliáceas}

A metodologia para infestação e obtenção dos ovos de moscabranca foram os mesmos do item 3.6.1. Foram utilizados quatro tratamentos com sete repetições, sendo que cada repetição correspondeu à média de duas gaiolas. Os tratamentos utilizados foram o extrato aquoso de sementes de nim e extratos aquoso e clorofórmico de ramos de T. pallida, todos a 3\%, além da testemunha (água). A aplicação foi feita 24 h após o início do experimento.

\subsubsection{Efeito ovicida de extratos aquosos de sementes de nim por vias sistêmica e translaminar}

A metodologia para infestação e obtenção dos ovos de moscabranca foram os mesmos do item 3.6.1. Foram utilizados cinco tratamentos com cinco repetições no primeiro experimento e seis no segundo, sendo que cada repetição correspondeu à média de duas gaiolas. Os tratamentos utilizados foram o extrato aquoso de sementes de nim a 3 e 10\%, por via sistêmica e por via translaminar, além da testemunha (água). Na avaliação do efeito sistêmico, $20 \mathrm{ml}$ do extrato nas concentrações de 3 e 10\% foram colocadas na base da planta a qual já continha nos folíolos os ovos de $24 \mathrm{~h}$ de idade, nos respectivos tratamentos. $\mathrm{Na}$ avaliação do efeito translaminar, o extrato nas duas concentrações foram aplicados na face adaxial de folhas infestadas com ovos de $24 \mathrm{~h}$ de idade. 


\subsubsection{Efeito ovicida de extratos aquoso e clorofórmico de meliáceas por vias sistêmica e translaminar}

A metodologia para infestação e obtenção dos ovos de moscabranca foram os mesmos do item 3.6.1. Foram utilizados cinco tratamentos com seis repetições, sendo que cada repetição correspondeu à média de duas gaiolas. Os tratamentos utilizados foram o extrato aquoso de sementes de nim e o extrato clorofórmico de ramos de T. pallida, ambos a 3\%, por via sistêmica e por via translaminar, além da testemunha (água). A aplicação foi feita conforme o item 3.6.3.

\subsection{Análise estatística}

Os dados obtidos em todos os experimentos foram submetidos à análise de variância e no caso de efeito significativo dos tratamentos, as médias foram comparadas pelo teste de Tukey ao nível de 5\% de probabilidade. 


\section{RESULTADOS E DISCUSSÃO}

\subsection{Determinação das concentrações adequadas dos extratos a serem utilizadas nos experimentos}

\subsubsection{Ação translaminar}

\subsubsection{Experimento 1 (laboratório)}

Os três tratamentos à base de extratos aquosos de sementes de nim (Azadirachta indica) reduziram a sobrevivência das ninfas de Bemisia tabaci (Genn., 1889) biótipo B (Tabela 1). As maiores mortalidades ninfais foram constatadas nas concentrações de 5 e 10\% (94,31 e 99,79\%, respectivamente), diferindo da encontrada na concentração de 1\% (54,57\%), enquanto na testemunha a mortalidade foi de $12,52 \%$.

Como o propósito desse experimento era o de selecionar uma concentração de extrato de sementes de nim que provocasse mortalidade ninfal moderada para se comparar com os demais extratos nas etapas seguintes, excluiu-se a maior concentração (10\%) na repetição desse experimento, substituindo-a por $0,5 \%$, já que na concentração mais alta a mortalidade encontrada tinha sido próxima de $100 \%$. 
Tabela 1. Médias $( \pm$ EP) de mortalidade de ninfas de primeiro ínstar de Bemisia tabaci biótipo $\mathrm{B}$, em folíolo de tomateiro com a superfície adaxial tratada com extratos aquosos de sementes de nim. Temp.: $21,25 \pm 10,02^{\circ} \mathrm{C}$; UR: $68,33 \pm 31,20 \%$; fotofase: $12 \mathrm{~h}$

\begin{tabular}{lc}
\hline Extratos & Mortalidade ninfal (\%) $)^{1}$ \\
\hline Nim 1\% & $54,57 \pm 25,92 \mathrm{~b}$ \\
Nim 5\% & $94,31 \pm 2,68 \mathrm{a}$ \\
Nim 10\% & $99,79 \pm 0,64 \mathrm{a}$ \\
Testemunha & $12,52 \pm 12,92 \mathrm{c}$ \\
\hline
\end{tabular}

${ }^{1}$ Médias seguidas de mesma letra não diferem entre si, pelo teste de Tukey $(P \leq$ $0,05)$.

\subsubsection{Experimento 2 (casa de vegetação)}

$\mathrm{Na}$ primeira repetição do experimento em casa de vegetação, o tratamento com nim a $5 \%$ provocou a maior mortalidade $(93,06 \%)$, vindo a seguir o tratamento com nim a $1 \%(73,74 \%)$. Os valores obtidos nestes dois tratamentos diferiram daqueles verificados com o extrato de nim a 0,5\% e na testemunha (28,11 e 15,72\%, respectivamente), os quais não diferiram entre si (Tabela 2).

$\mathrm{Na}$ segunda repetição desse experimento, com os mesmos tratamentos, visando confirmar os dados obtidos, o extrato de nim provocou, em todas as concentrações, aumento significativo na mortalidade ninfal em comparação com a testemunha. O extrato a $5 \%$ foi o mais efetivo, provocando $99,61 \%$ de mortalidade, seguido do tratamento a 1\% (68,42\%), que também diferiu do valor obtido a $0,5 \%(38,22 \%)$. A mortalidade na testemunha foi de $19,58 \%$ (Tabela 3). 
Nestes dois experimentos, na concentração de 1\%, a mortalidade foi de cerca de $70 \%$, considerada adequada para utilização nos experimentos para avaliação de ação translaminar com extratos de Trichilia pallida.

O efeito inseticida do nim por via translaminar sobre mosca-branca ainda não havia sido caracterizado. Assim, esta informação reveste-se de grande importância porque este inseto tem o hábito de permanecer sob a folha, o que dificulta o seu controle. Além disso, o fato de os compostos inseticidas do extrato de nim apresentarem ação translaminar na planta garante maior proteção contra as variações ambientais, tais como temperatura e raios ultravioletas, o que tende a aumentar a persistência do produto. Coudriet et al. (1985a) observaram que um extrato de sementes de nim diluído em água morna $\left(65^{\circ} \mathrm{C}\right)$, acrescido de um surfactante, manteve persistência por 14 dias, provocando repelência para oviposição e mortalidade ninfal de mosca-branca. Assim, é possível que além da presença do coadjuvante, a persistência relativamente alta também tenha sido causada pela translocação dos compostos inseticidas entre as superfícies foliares da planta.

Tabela 2. Médias ( \pm EP) de mortalidade de ninfas de primeiro ínstar de Bemisia tabaci biótipo $\mathrm{B}$, em folíolo de tomateiro com a superfície adaxial tratada com extratos aquosos de sementes de nim. Repetição 1. Temp.: 27,31 $\pm 5,94^{\circ} \mathrm{C}$; UR: $64,19 \pm 30,41 \%$; fotoperíodo natural

\begin{tabular}{ll}
\hline Extratos & Mortalidade ninfal $(\%)^{1}$ \\
\hline Nim 0,5\% & $28,11 \pm 11,03 \mathrm{c}$ \\
Nim 1\% & $73,74 \pm 10,38 \mathrm{~b}$ \\
Nim 5\% & $93,06 \pm 0,91 \mathrm{a}$ \\
Testemunha & $15,72 \pm 07,55 \mathrm{c}$ \\
\hline
\end{tabular}

${ }^{1}$ Médias seguidas de mesma letra não diferem entre si, pelo teste de Tukey ( $\mathrm{P} \leq$ $0,05)$. 
Tabela 3. Médias ( \pm EP) de mortalidade de ninfas de primeiro ínstar de Bemisia tabaci biótipo $\mathrm{B}$, em folíolo de tomateiro com a superfície adaxial tratada com extratos aquosos de sementes de nim. Repetição 2. Temp.: 24,64 $\pm 3,82^{\circ} \mathrm{C}$; UR: $77,64 \pm 19,83 \%$; fotoperíodo natural

\begin{tabular}{ll}
\hline Extratos & Mortalidade ninfal $(\%)^{1}$ \\
\hline Nim 0,5\% & $38,22 \pm 17,33 \mathrm{c}$ \\
Nim 1\% & $68,42 \pm 10,77 \mathrm{~b}$ \\
Nim 5\% & $99,61 \pm 0,77 \mathrm{a}$ \\
Testemunha & $19,58 \pm 04,76 \mathrm{~d}$ \\
\hline
\end{tabular}

${ }^{1}$ Médias seguidas de mesma letra não diferem entre si, pelo teste de Tukey $(P \leq$ 0,05).

\subsubsection{Ação sistêmica}

\subsubsection{Experimento 1}

A mortalidade das ninfas de $B$. tabaci foi $100 \%$ nos tratamentos com 5 e 10\% de concentração e 99,65\% a 1\% (Tabela 4). A constatação de baixa mortalidade na testemunha (4,12\%), por outro lado, indica que não houve problemas climáticos ou de manipulação de insetos, podendo-se inferir, portanto, que os tratamentos, mesmo na menor concentração, foram altamente eficientes no controle da mosca-branca.

Analogamente ao que foi mencionado no experimento para avaliação da ação translaminar (item 4.1.1), também nesse experimento, o objetivo era encontrar uma concentração que causasse mortalidade ninfal moderada. Por essa razão, o experimento foi repetido excluindo-se a concentração mais elevada (10\%) e incluindo-se a concentração de 0,5\%. Por outro lado, como também foi 
observado que alguns minutos após a aplicação do extrato, o solo já estava encharcado, optou-se pela redução, de $50 \mathrm{ml}$ para $30 \mathrm{ml}$, do volume de suspensão colocado por vaso.

Tabela 4. Médias $( \pm$ EP) de mortalidade de ninfas de primeiro ínstar de Bemisia tabaci biótipo $\mathrm{B}$, em plantas de tomateiro cultivadas em solo tratado com extratos aquosos (50 $\mathrm{ml}$ por planta) de sementes de nim. Temp.: $23,25 \pm 7,18^{\circ} \mathrm{C}$; UR: $73,38 \pm 25,00 \%$; fotoperíodo natural

\begin{tabular}{lc}
\hline Extratos & Mortalidade ninfal $(\%)^{1}$ \\
\hline Nim $1 \%$ & $99,65 \pm 0,43$ \\
Nim $5 \%$ & $100,00 \pm 0,00$ \\
Nim $10 \%$ & $100,00 \pm 0,00$ \\
Testemunha & $4,12 \pm 2,78$ \\
\hline
\end{tabular}

${ }^{1}$ Dados não analisados estatisticamente

\subsubsection{Experimento 2}

Em todos os tratamentos com extrato, houve aumento na mortalidade ninfal em relação à testemunha (Tabela 5), constatando-se os maiores valores a 5 e 1\% (99,71 e 96,17\%, respectivamente). A 0,5\%, a mortalidade ninfal atingiu $73,23 \%$ e embora tenha sido inferior aos valores registrados nas maiores concentrações, ainda assim foi cerca de sete vezes superior à encontrada na testemunha (10,07\%). 
Tabela 5. Médias ( \pm EP) de mortalidade de ninfas de primeiro ínstar de Bemisia tabaci biótipo $\mathrm{B}$, em plantas de tomateiro cultivadas em solo tratado com extratos aquosos (30 $\mathrm{ml}$ por planta) de sementes de nim. Temp.: $22,13 \pm 8,48^{\circ} \mathrm{C}$; UR: $73,56 \pm 24,51 \%$; fotoperíodo natural

\begin{tabular}{lc}
\hline Extratos & Mortalidade ninfal $(\%)^{1}$ \\
\hline Nim 0,5\% & $73,23 \pm 10,84 \mathrm{~b}$ \\
Nim 1\% & $96,17 \pm 2,14 \mathrm{a}$ \\
Nim 5\% & $99,71 \pm 0,57 \mathrm{a}$ \\
Testemunha & $10,07 \pm 2,98 \quad \mathrm{c}$ \\
\hline
\end{tabular}

${ }^{1}$ Médias seguidas de mesma letra não diferem entre si, pelo teste de Tukey $(P \leq$ $0,05)$.

Como, mesmo na menor concentração, a mortalidade ainda foi relativamente alta, o experimento foi repetido diminuindo-se de 30 para $20 \mathrm{ml}$ o volume de extrato utilizado por vaso (contendo uma planta).

\subsubsection{Experimento 3}

Também nesse experimento, todos os extratos provocaram mortalidade ninfal superior à encontrada na testemunha (Tabela 6). A 5\% ocorreu 99,99\% de mortalidade, seguindo-se as concentrações de 1 e 0,5\% que causaram 88,06 e $74,50 \%$, respectivamente, enquanto na testemunha, a mortalidade foi de $8,10 \%$. Apesar de nesse experimento ter havido redução progressiva na eficiência, comparando-se as três concentrações, ainda assim, mesmo na menor concentração, a mortalidade foi cerca de nove vezes maior que a registrada na testemunha.

Comparando-se, por outro lado, os volumes de extrato utilizados ( 50 , 30 e $20 \mathrm{ml}$ ) nas duas concentrações (5 e 1\%), comuns aos três experimentos, 
verifica-se que praticamente não houve diminuição do efeito sistêmico do produto, em conseqüência da redução do volume aplicado, exceto na concentração de 1\%, em que a mortalidade reduziu-se de $99,65 \%$, com volume de $50 \mathrm{ml}$, para $88,06 \%$, com volume de $20 \mathrm{ml}$.

Assim, considerando-se que o objetivo do experimento era encontrar uma concentração adequada para estudos de ação sistêmica dos extratos de $T$. pallida em relação à mosca-branca, selecionou-se a concentração de 0,5\% e o volume de $20 \mathrm{ml}$ por vaso contendo uma planta.

O efeito do nim sobre mosca-branca já havia sido relatado por Coudriet et al. (1985a) e Prabhaker et al. (1999). O efeito sistêmico do nim em aplicações no solo possivelmente aumenta a persistência do produto comparado à aplicação na face adaxial, mesmo que haja translocação entre as superfícies foliares, pois a azadiractina, principal componente ativo do nim, é sensível à fotodegradação, segundo Weintraub \& Horowitz (1997) que sugeriram a aplicação do nim na água de irrigação.

Tabela 6. Médias ( \pm EP) de mortalidade de ninfas de primeiro ínstar de Bemisia tabaci biótipo $\mathrm{B}$, em plantas de tomateiro cultivadas em solo tratado com extratos aquosos ( $20 \mathrm{ml}$ por planta) de sementes de nim. Temp.: $22,33 \pm 8,26^{\circ} \mathrm{C}$; UR: $73,50 \pm 25,28 \%$; fotoperíodo natural

\begin{tabular}{lc}
\hline Extratos & Mortalidade ninfal $(\%)^{1}$ \\
\hline Nim 0,5\% & $74,50 \pm 7,87 \mathrm{c}$ \\
Nim $1 \%$ & $88,06 \pm 3,93 \mathrm{~b}$ \\
Nim $5 \%$ & $99,99 \pm 0,02 \mathrm{a}$ \\
Testemunha & $8,10 \pm 5,37 \mathrm{~d}$ \\
\hline
\end{tabular}

${ }^{1}$ Médias seguidas de mesma letra não diferem entre si, pelo teste de Tukey $(P \leq$ $0,05)$. 


\subsubsection{Ação de contato}

\subsubsection{Experimento 1}

Em todos os tratamentos foi observado aumento na mortalidade ninfal em relação à testemunha (Tabela 7). A 5 e 1\%, os valores médios (98,88 e $97,50 \%$, respectivamente) foram maiores que a $0,5 \%$ (90,13\%), enquanto na testemunha a mortalidade atingiu 13,63\%.

Apesar de na avaliação da ação de contato ter sido suprimida a maior concentração (10\%) utilizada nos experimentos iniciais para os outros tipos de ação, ainda assim, mesmo na menor concentração (0,5\%), a mortalidade foi relativamente alta (maior que $90 \%$ ) para o propósito do experimento que era encontrar uma concentração adequada em que o extrato de nim pudesse ser comparado com outros extratos menos ou mais eficientes. Por esta razão, o experimento foi repetido utilizando-se concentrações variáveis entre 0,1 e $0,5 \%$.

\subsubsection{Experimento 2}

Em todos os tratamentos a mortalidade ninfal foi maior que a registrada na testemunha, constatando-se valores significativamente decrescentes ( 87,$38 ; 74,17$ e 50,42\%) nas concentrações de 0,5; 0,3 e 0,1\%, respectivamente, enquanto na testemunha a mortalidade foi de $4,11 \%$ (Tabela 8 ).

Com base nestes dados, selecionou-se a concentração de 0,3\% para a avaliação da ação de contato dos extratos de $T$. pallida sobre a mosca-branca.

Embora não seja possível estabelecer uma comparação estatística entre as eficiências do extrato de nim nos três tipos de ação testados, pois essa avaliação foi feita em experimentos distintos, é possível notar variações entre os mesmos. Assim, se for considerada uma eficiência de cerca de $70 \%$, constata-se que para o efeito translaminar foi necessária uma concentração de $1 \%$, enquanto que para os efeitos sistêmico e de contato, a mortalidade de cerca de $70 \%$ foi 
obtida com concentrações menores ( 0,5 e $0,3 \%$, respectivamente). Com base nos resultados obtidos, entretanto, é difícil afirmar qual dos mecanismos de ação do nim é mais eficiente, uma vez que, em razão das técnicas utilizadas, mesmo com a utilização de uma mesma concentração do extrato, o inseto fica exposto a diferentes quantidades do produto em cada caso. De qualquer modo, poderia se inferir que a maior concentração aparentemente necessária na ação translaminar em relação à ação sistêmica, poderia se dever, ao menos em parte, ao fato de que no primeiro caso, o produto, por ser aplicado nas folhas, sofre fotodegradação, enquanto que no segundo caso, ele é aplicado no solo, onde rapidamente se infiltra e não fica sujeito à ação da luz. Por outro lado, acredita-se que pelo fato de o inseto permanecer na superfície abaxial da folha, a eficácia do produto no campo tenderá a ser menor porque nem sempre haverá contato do inseto com o produto nas aplicações convencionais.

Tabela 7. Médias ( \pm EP) de mortalidade de ninfas de terceiro ínstar de Bemisia tabaci biótipo $\mathrm{B}$ tratadas topicamente com extratos aquosos de sementes de nim. Temp.: 28,67 $\pm 11,63^{\circ} \mathrm{C}$; UR: $69,58 \pm 31,44 \%$; fotoperíodo natural

\begin{tabular}{lc}
\hline Extratos & Mortalidade ninfal $(\%)^{1}$ \\
\hline Nim 0,5\% & $90,13 \pm 3,36 \mathrm{~b}$ \\
Nim 1\% & $97,50 \pm 2,71 \mathrm{a}$ \\
Nim 5\% & $98,88 \pm 1,23 \mathrm{a}$ \\
Testemunha & $13,63 \pm 3,81 \mathrm{c}$ \\
\hline
\end{tabular}

${ }^{1}$ Médias seguidas de mesma letra não diferem entre si, pelo teste de Tukey $(\mathrm{P} \leq$ $0,05)$. 
Tabela 8. Médias ( \pm EP) de mortalidade de ninfas de terceiro ínstar de Bemisia tabaci biótipo B tratadas topicamente com extratos aquosos de sementes de nim. Temp.: 26,31 $\pm 07,13^{\circ} \mathrm{C}$; UR: $68,33 \pm 25,40 \%$; fotoperíodo natural

\begin{tabular}{lc}
\hline Extratos & Mortalidade ninfal $(\%)^{1}$ \\
\hline Nim 0,1\% & $50,42 \pm 5,32 \mathrm{a}$ \\
Nim 0,3\% & $74,17 \pm 10,68 \mathrm{~b}$ \\
Nim 0,5\% & $87,38 \pm 4,83 \mathrm{c}$ \\
Testemunha & $4,11 \pm 2,10 \mathrm{~d}$ \\
\hline
\end{tabular}

${ }^{1}$ Médias seguidas de mesma letra não diferem entre si, pelo teste de Tukey $(\mathrm{P} \leq$ $0,05)$.

\subsection{Avaliação da atividade de extratos orgânicos de T. pallida}

No primeiro experimento (Tabela 9 e Figura 2), a mortalidade das ninfas de mosca-branca no tratamento à base de extrato aquoso de sementes de nim $(98,45 \%)$ foi maior do que em todos os demais tratamentos. Com os extratos aquoso, clorofórmico, metanólico e etanólico de ramos de $T$. pallida, as mortalidades, mesmo não atingindo $60 \%$ (57,92; 57,91; 55,27 e 53,91\%, respectivamente), diferiram significativamente do valor constatado com o extrato hexânico (29,32\%). Este valor, entretanto, embora não tenha diferido daquele encontrado na testemunha acetona $(15,00 \%)$, foi superior àquele registrado na testemunha água $(10,11 \%)$, embora entre as referidas testemunhas não tenha havido diferença significativa.

No segundo experimento (Tabela 10 e Figura 3), o maior valor de mortalidade novamente ocorreu no tratamento com extrato aquoso de sementes de nim (98,60\%), seguido daqueles constatados nos extratos clorofórmico, aquoso, metanólico e etanólico de ramos de $T$. pallida $(56,73 ;$; 51,98; 48,94 e 
$45,44 \%$, respectivamente) que diferiram dos demais. As mortalidades encontradas com extrato hexânico, testemunha acetona e testemunha água $(20,96 ; 14,04$ e $9,48 \%$, respectivamente) não diferiram entre si.

A ineficiência do extrato hexânico nos dois experimentos, de certa forma, está de acordo com resultados obtidos por outros autores que também observaram que extratos altamente apolares são menos eficientes que aqueles com polaridade intermediária (Ascher et al., 1984; Roel et al., 2000 e Saito et al., 1989). Com base nesse conhecimento, alguns autores têm preferido obter extratos botânicos usando solventes de polaridade intermediária, evitando o emprego de extratos apolares (Cubillo et al., 1999; Gómez et al., 1997b e Neal et al., 1994).

Embora os valores de mortalidade ninfal nos tratamentos com extratos clorofórmico, metanólico e etanólico não tenham diferido entre si, houve tendência, nos dois experimentos, de maior valor com o extrato clorofórmico, razão pela qual esse extrato foi selecionado para utilização nas etapas seguintes.

Tabela 9. Médias $( \pm$ EP) de mortalidade de ninfas de primeiro ínstar de Bemisia tabaci biótipo $\mathrm{B}$, em tomateiro pulverizado com extratos aquosos e orgânicos de meliáceas. Experimento 1. Temp.: 22,33 $\pm 8,26^{\circ} \mathrm{C}$; UR: $73,50 \pm 25,28 \%$; fotoperíodo natural

\begin{tabular}{lc}
\hline Extratos & Mortalidade ninfal (\%) \\
\hline Sementes de nim (aquoso) & $98,45 \pm 0,56 \mathrm{a}$ \\
Ramos de $T$. pallida (aquoso) & $57,92 \pm 8,07 \mathrm{~b}$ \\
Ramos de $T$. pallida (clorofórmico) & $57,91 \pm 7,71 \mathrm{~b}$ \\
Ramos de $T$. pallida (metanólico) & $55,27 \pm 7,90 \mathrm{~b}$ \\
Ramos de $T$. pallida (etanólico) & $53,91 \pm 11,23 \mathrm{~b}$ \\
Ramos de $T$. pallida (hexânico) & $29,32 \pm 4,75 \mathrm{c}$ \\
Testemunha (acetona 5\%) & $15,00 \pm 4,65 \mathrm{~cd}$ \\
Testemunha (água) & $10,11 \pm 2,48 \mathrm{~d}$ \\
\hline
\end{tabular}


${ }^{1}$ Médias seguidas de mesma letra não diferem entre si, pelo teste de Tukey $(P \leq 0,05)$.

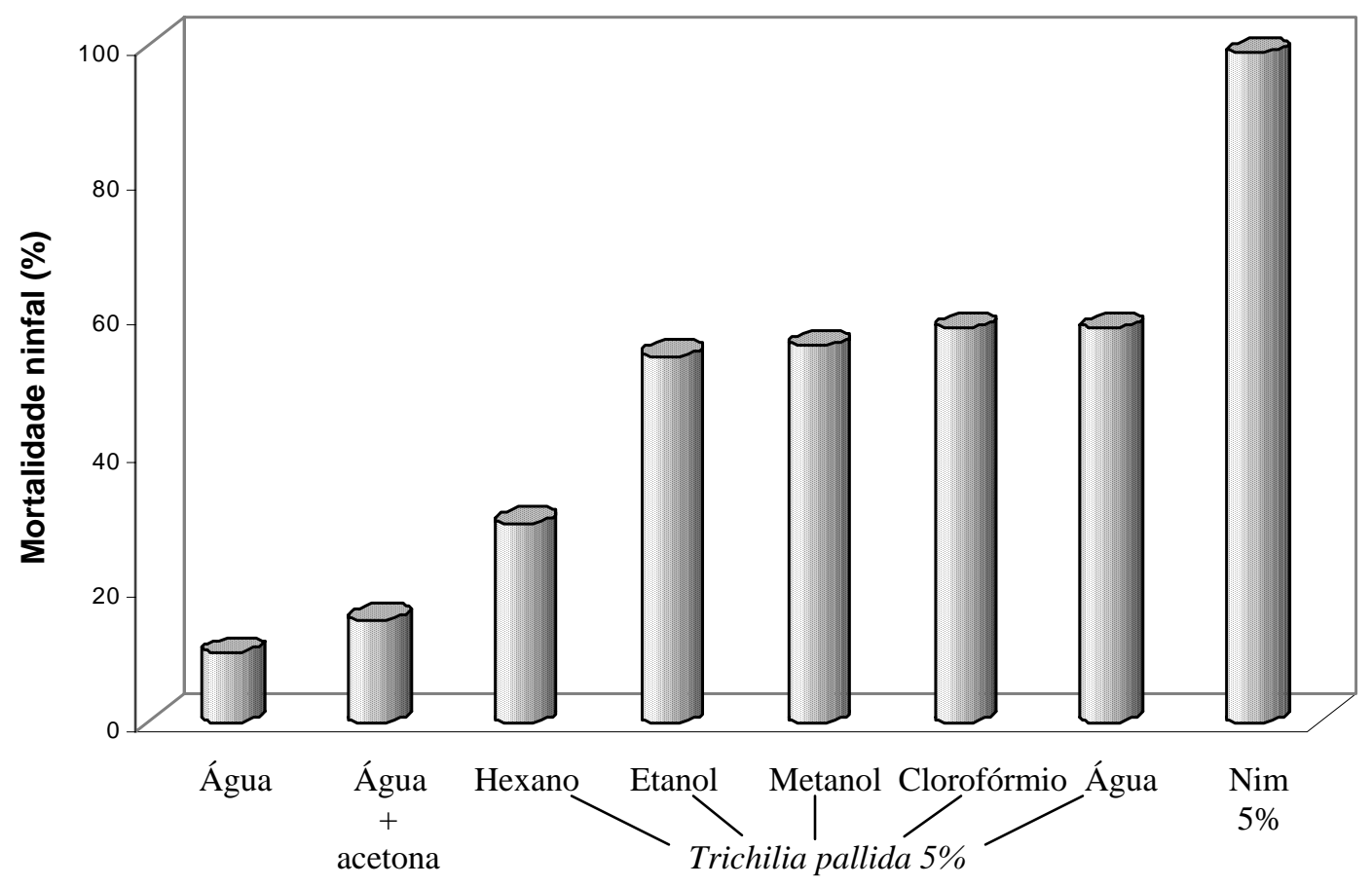

Figura 2- Médias ( \pm EP) de mortalidade de ninfas de primeiro ínstar de Bemisia tabaci biótipo $\mathrm{B}$, em tomateiro pulverizado com extratos aquosos e orgânicos de meliáceas. Experimento 1. Temp.: 22,33 $\pm 8,26^{\circ} \mathrm{C}$; UR: $73,50 \pm 25,28 \%$; fotoperíodo natural 
Tabela 10. Médias ( \pm EP) de mortalidade de ninfas de primeiro ínstar de Bemisia tabaci biótipo $\mathrm{B}$, em tomateiro pulverizado com extratos aquosos $\mathrm{e}$ orgânicos de meliáceas. Experimento 2. Temp.: 22,43 $\pm 8,81^{\circ} \mathrm{C}$; UR: 73,00 $\pm 25,49 \%$; fotoperíodo natural

\begin{tabular}{lc}
\hline Extratos & Mortalidade ninfal (\%) \\
\hline Sementes de nim (aquoso) & $98,60 \pm 0,65 \mathrm{a}$ \\
Ramos de $T$. pallida (aquoso) & $51,98 \pm 6,51 \mathrm{~b}$ \\
Ramos de T. pallida (clorofórmico) & $56,73 \pm 4,68 \mathrm{~b}$ \\
Ramos de T. pallida (metanólico) & $48,94 \pm 12,32 \mathrm{~b}$ \\
Ramos de T. pallida (etanólico) & $45,44 \pm 8,26 \mathrm{~b}$ \\
Ramos de T. pallida (hexânico) & $20,96 \pm 5,03 \mathrm{c}$ \\
Testemunha (acetona 5\%) & $14,04 \pm 5,51 \mathrm{c}$ \\
Testemunha (água) & $9,48 \pm 2,70 \mathrm{c}$ \\
\hline
\end{tabular}

${ }^{1}$ Médias seguidas de mesma letra não diferem entre si, pelo teste de Tukey $(\mathrm{P} \leq$ $0,05)$. 


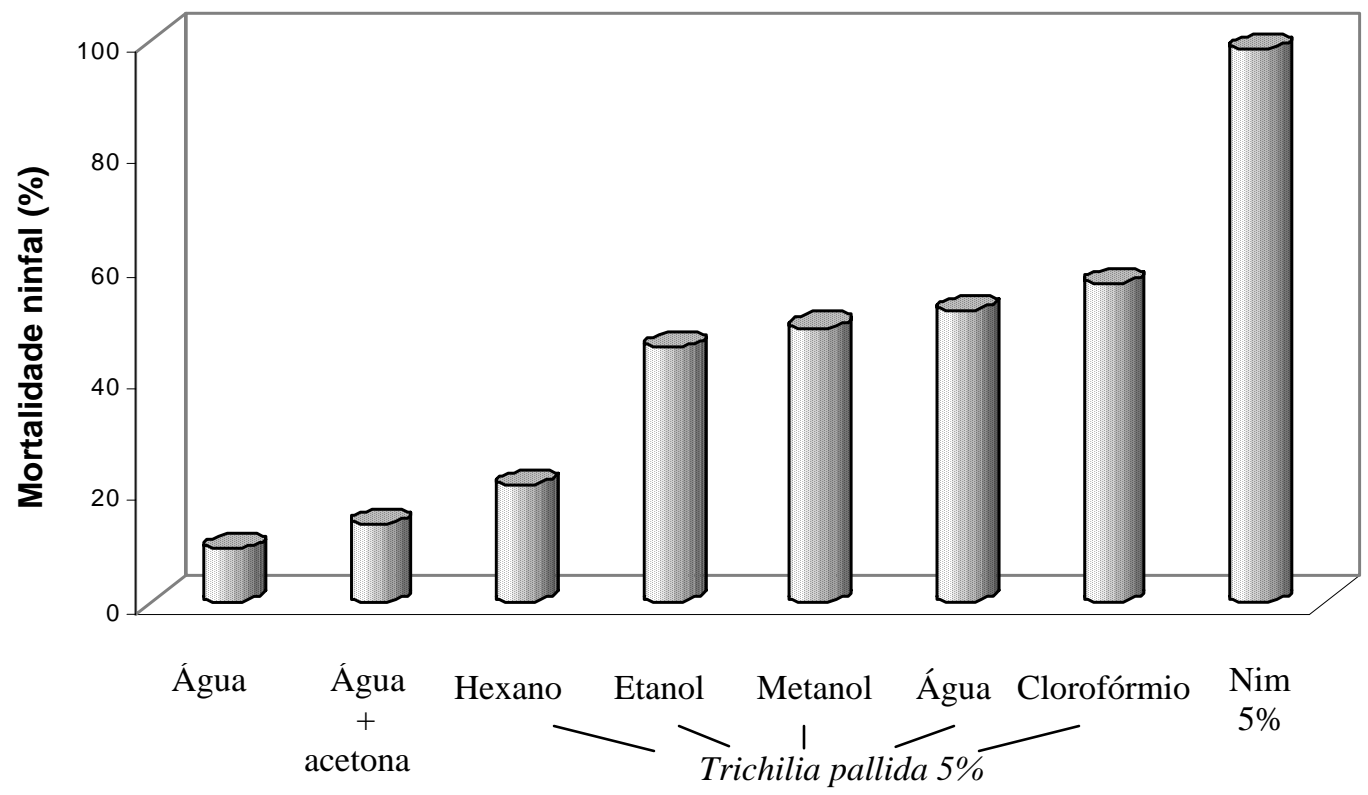

Figura 3- Médias ( \pm EP) de mortalidade de ninfas de primeiro ínstar de Bemisia tabaci biótipo $\mathrm{B}$, em tomateiro pulverizado com extratos aquosos e orgânicos de meliáceas. Experimento 2. Temp.: 22,43 $\pm 8,81^{\circ} \mathrm{C}$; UR: $73,00 \pm 25,49 \%$; fotoperíodo natural

4.3 Avaliação do efeito inseticida de extratos clorofórmico e aquoso de $T$. pallida e aquoso de sementes de nim

\subsubsection{Ação translaminar}

Nos dois experimentos para avaliação do efeito translaminar, apenas o extrato aquoso de sementes de nim provocou mortalidade ninfal (56,04 e $63,15 \%$, respectivamente), superior à registrada na testemunha. Por outro lado, apesar de, aparentemente, ter ocorrido algum efeito translaminar com os extratos aquoso e clorofórmico de ramos de $T$. pallida, caracterizado pela mortalidade 
ninfal de 25,18 e $28,83 \%$ no primeiro experimento e 29,59 e $31,05 \%$ no segundo experimento, respectivamente, estes valores não diferiram dos encontrados nas respectivas testemunhas $(15,89$ e 10,37\%) (Tabelas 11 e 12).

Tabela 11. Médias $( \pm$ EP) de mortalidade de ninfas de primeiro ínstar de Bemisia tabaci biótipo $\mathrm{B}$, em folíolo de tomateiro com a superfície adaxial tratada com extratos de meliáceas. Temp.: 23,19 $\pm 5,88^{\circ} \mathrm{C}$; UR: 80,13 \pm 17,98\%; fotoperíodo natural

\begin{tabular}{lc}
\hline Extratos & Mortalidade ninfal (\%) \\
\hline Sementes de nim 1\% (aquoso) & $56,04 \pm 12,26 \mathrm{a}$ \\
Ramos de $T$. pallida 1\% (aquoso) & $25,18 \pm 6,89 \mathrm{~b}$ \\
Ramos de $T$. pallida 1\% (clorofórmico) & $28,83 \pm 13,07 \mathrm{~b}$ \\
Testemunha & $15,89 \pm 4,04 \mathrm{~b}$ \\
\hline
\end{tabular}

${ }^{1}$ Médias seguidas de mesma letra não diferem entre si, pelo teste de Tukey $(\mathrm{P} \leq$ $0,05)$.

Tabela 12. Médias ( \pm EP) de mortalidade de ninfas de primeiro ínstar de Bemisia tabaci biótipo $\mathrm{B}$, em folíolo de tomateiro com a superfície adaxial tratada com extratos de meliáceas. Temp.: $26,35 \pm 7,44^{\circ} \mathrm{C}$; UR: 76,55 \pm 22,58\%; fotoperíodo natural

\begin{tabular}{lc}
\hline Extratos & Mortalidade ninfal (\%) \\
\hline Sementes de nim 1\%(aquoso) & $63,15 \pm 6,64 \mathrm{a}$ \\
Ramos de T. pallida 1\% (aquoso) & $29,59 \pm 15,50 \mathrm{~b}$ \\
Ramos de T. pallida 1\% (clorofórmico) & $31,05 \pm 9,43 \mathrm{~b}$ \\
Testemunha & $10,37 \pm 7,39 \mathrm{~b}$ \\
\hline
\end{tabular}

${ }^{1}$ Médias seguidas de mesma letra não diferem entre si, pelo teste de Tukey ( $\mathrm{P} \leq$ $0,05)$. 


\subsubsection{Ação sistêmica}

No primeiro experimento, apenas com extrato aquoso de sementes de nim foi constatada mortalidade ninfal (61,33\%) superior à registrada na testemunha. Os valores obtidos com extratos aquoso e clorofórmico de ramos de T. pallida não diferiram entre si (24,01 e $22,65 \%$, respectivamente) e tampouco do valor obtido na testemunha $(10,12 \%)$ (Tabela 13$)$.

No segundo experimento, novamente o extrato aquoso de sementes de nim apresentou maior eficiência propiciando mortalidade ninfal de 66,03\%, a qual diferiu das constatadas nos demais tratamentos. Nesse experimento, entretanto, a mortalidade registrada com extrato aquoso de ramos de $T$. pallida $(23,46 \%)$ também superou à verificada na testemunha (9,30\%). Com o extrato clorofórmico, o valor obtido foi intermediário $(19,14 \%)$, não diferindo daqueles verificados no extrato aquoso de T. pallida e na testemunha (Tabela 14).

Tabela 13. Médias ( \pm EP) de mortalidade de ninfas de primeiro ínstar de Bemisia tabaci biótipo $\mathrm{B}$, em plantas de tomateiro cultivadas em solo tratado com extratos de meliáceas. Experimento 1. Temp.: 23,19 $\pm 5,88^{\circ} \mathrm{C}$; UR: $80,13 \pm 17,98 \%$; fotoperíodo natural

\begin{tabular}{ll}
\hline Extratos & Mortalidade ninfal $(\%)^{1}$ \\
\hline Sementes de nim 0,5\% (aquoso) & $61,33 \pm 7,42 \mathrm{a}$ \\
Ramos de $T$. pallida 0,5\% (aquoso) & $24,01 \pm 11,08 \mathrm{~b}$ \\
Ramos de $T$. pallida 0,5\% (clorofórmico) & $22,65 \pm 10,59 \mathrm{~b}$ \\
Testemunha & $10,12 \pm 3,62 \mathrm{~b}$ \\
\hline
\end{tabular}

${ }^{1}$ Médias seguidas de mesma letra não diferem entre si, pelo teste de Tukey ( $\mathrm{P} \leq$ $0,05)$. 
Tabela 14. Médias ( \pm EP) de mortalidade de ninfas de primeiro ínstar de Bemisia tabaci biótipo $\mathrm{B}$, em plantas de tomateiro cultivadas em solo tratado com extratos de meliáceas. Experimento 2. Temp.: $22,67 \pm 8,14^{\circ} \mathrm{C}$; UR: $76,15 \pm 20,25 \%$; fotoperíodo natural

\begin{tabular}{lc}
\hline Extratos & Mortalidade ninfal (\%) \\
\hline Sementes de nim 0,5\% (aquoso) & $66,03 \pm 7,54 \mathrm{a}$ \\
Ramos de T. pallida 0,5\% (aquoso) & $23,46 \pm 12,75 \mathrm{~b}$ \\
Ramos de T. pallida 0,5\% (clorofórmico) & $19,14 \pm 7,18 \mathrm{bc}$ \\
Testemunha & $9,30 \pm 3,10 \mathrm{c}$ \\
\hline
\end{tabular}

${ }^{1}$ Médias seguidas de mesma letra não diferem entre si, pelo teste de Tukey $(\mathrm{P} \leq$ $0,05)$.

\subsubsection{Ação de contato}

No primeiro experimento, a mortalidade registrada no tratamento com extrato aquoso de sementes de nim $(71,85 \%)$ foi maior que as obtidas nos tratamentos com extratos clorofórmico e aquoso de ramos de $T$. pallida e na testemunha $(24,92 ; 24,32$ e $10,53 \%$, respectivamente), as quais não diferiram entre si (Tabela 15).

No segundo experimento, novamente a mortalidade ninfal no extrato aquoso de sementes de nim (68,88\%) superou a constatada nos demais tratamentos. Nesse experimento, entretanto, o extrato aquoso de ramos de $T$. pallida também mostrou eficiência provocando mortalidade de $27,52 \%$, a qual foi superior à registrada na testemunha (12,55\%), embora não tenha diferido do valor obtido com o extrato clorofórmico $(23,29 \%)$ (Tabela 16$)$.

Durante todo o experimento, os resultados foram bastante consistentes com relação ao extrato de sementes de nim, utilizado desde a 
primeira etapa. Com relação a $T$. pallida, as concentrações utilizadas foram insuficientes para se afirmar a existência dos diferentes tipos de efeitos.

Tabela 15. Médias ( \pm EP) de mortalidade de ninfas de terceiro ínstar de Bemisia tabaci biótipo $\mathrm{B}$, tratadas topicamente no primeiro ínstar, com extratos de meliáceas. Experimento 1. Temp.: $26,81 \pm 8,13^{\circ} \mathrm{C}$; UR: $75,06 \pm$ 23,35\%; fotoperíodo natural

\begin{tabular}{lc}
\hline Extratos & Mortalidade ninfal (\%) \\
\hline Sementes de nim 0,3\% (aquoso) & $71,85 \pm 12,36 \mathrm{a}$ \\
Ramos de T. pallida 0,3\% (aquoso) & $24,32 \pm 13,86 \mathrm{~b}$ \\
Ramos de T. pallida 0,3\% (clorofórmico) & $24,92 \pm 12,00 \mathrm{~b}$ \\
Testemunha & $10,53 \pm 4,88 \mathrm{~b}$ \\
\hline
\end{tabular}

${ }^{1}$ Médias seguidas de mesma letra não diferem entre si, pelo teste de Tukey ( $\mathrm{P} \leq$ $0,05)$.

Tabela 16. Médias ( \pm EP) de mortalidade de ninfas de terceiro ínstar de Bemisia tabaci biótipo $\mathrm{B}$, tratadas topicamente no primeiro ínstar, com extratos de meliáceas. Experimento 2. Temp.: $27,38 \pm 8,27^{\circ} \mathrm{C}$; UR: 75,75 \pm 22,89\%; fotoperíodo natural

\begin{tabular}{lc}
\hline Extratos & Mortalidade ninfal (\%) \\
\hline Sementes de nim 0,3\% (aquoso) & $68,88 \pm 8,66 \mathrm{a}$ \\
Ramos de $T$. pallida 0,3\% (aquoso) & $27,52 \pm 12,16 \mathrm{~b}$ \\
Ramos de $T$. pallida 0,3\% (clorofórmico) & $23,29 \pm 9,51 \mathrm{bc}$ \\
Testemunha & $12,55 \pm 3,66 \mathrm{c}$ \\
\hline
\end{tabular}

${ }^{1}$ Médias seguidas de mesma letra não diferem entre si, pelo teste de Tukey ( $\mathrm{P} \leq$ 0,05 ). 


\subsection{Avaliação do efeito ovicida de extratos aquosos e orgânicos de meliáceas}

\subsubsection{Influência da idade do ovo no efeito ovicida do extrato aquoso de sementes de nim}

Não houve diferença no efeito ovicida do extrato de sementes de nim em função da idade em que os ovos da mosca-branca foram tratados, já que nas três idades testadas (24, 96 e 120h) os valores de inviabilidade dos ovos (26,40; 28,86 e 24,63\%, respectivamente) não diferiram entre si. A eficiência do extrato, entretanto, foi observada nas três situações, já que tais valores superaram aquele registrado na testemunha $(7,85 \%)$ (Tabela 17$)$.

Tabela 17. Médias ( \pm EP) de inviabilidade de ovos de Bemisia tabaci biótipo $B$, tratados em diferentes idades com extrato aquoso de sementes de nim, em tomateiro. Temp.: $25,50 \pm 5,38^{\circ} \mathrm{C}$; UR: $72,81 \pm 25,40 \%$; fotoperíodo natural

\begin{tabular}{lc}
\hline Idade do ovo & Ovos inviáveis (\%) ${ }^{1}$ \\
\hline $24 \mathrm{~h}$ & $26,40 \pm 9,12 \mathrm{a}$ \\
$96 \mathrm{~h}$ & $28,86 \pm 9,48 \mathrm{a}$ \\
$120 \mathrm{~h}$ & $24,63 \pm 12,05 \mathrm{a}$ \\
Testemunha & $7,85 \pm 4,07 \mathrm{~b}$ \\
\hline
\end{tabular}

${ }^{1}$ Médias seguidas de mesma letra não diferem entre si, pelo teste de Tukey $(P \leq$ $0,05)$.

\subsubsection{Efeito ovicida de extratos aquosos e orgânico de meliáceas}

O extrato aquoso de sementes de nim foi o único tratamento dentre os 
três testados que apresentou efeito ovicida provocando inviabilidade dos ovos $(27,09 \%)$ superior à registrada na testemunha $(5,84 \%)$. Com os extratos aquoso e clorofórmico de ramos de T. pallida, os valores médios foram intermediários (19,89 e $22,48 \%$, respectivamente) não diferindo daqueles registrados com nim e na testemunha (Tabela 18).

Tabela 18. Médias ( \pm EP) de inviabilidade de ovos de Bemisia tabaci biótipo $B$, tratados com extratos de meliáceas, em tomateiro. Temp.: 22,96 \pm $5,44^{\circ} \mathrm{C}$; UR: $72,61 \pm 25,58 \%$; fotoperíodo natural

\begin{tabular}{lc}
\hline Extratos & Ovos inviáveis (\%) \\
\hline Sementes de nim 3\% (aquoso) & $27,09 \pm 7,24 \mathrm{a}$ \\
Ramos de T. pallida 3\% (aquoso) & $19,89 \pm 9,36 \mathrm{ab}$ \\
Ramos de T. pallida 3\% (clorofórmico) & $22,48 \pm 13,16 \mathrm{ab}$ \\
Testemunha & $5,84 \pm 2,93 \mathrm{~b}$ \\
\hline
\end{tabular}

${ }^{1}$ Médias seguidas de mesma letra não diferem entre si, pelo teste de Tukey $(\mathrm{P} \leq$ $0,05)$.

\subsubsection{Efeito ovicida de extrato aquoso de sementes de nim por via sistêmica e translaminar}

Considerando-se os dois experimentos simultaneamente (Tabelas $19 \mathrm{e}$ 20), verifica-se que os valores de inviabilidade dos ovos de mosca-branca tratados com extrato aquoso de sementes de nim a 3 e 10\%, por via sistêmica e translaminar foram relativamente baixos variando de 14,32 a 17,81\%. Apesar da baixa eficiência, entretanto, estes valores foram superiores aos registrados nas respectivas testemunhas (6,97\% no primeiro experimento e $4,48 \%$ no segundo experimento), com exceção daqueles constatados no primeiro experimento com os tratamentos por via sistêmica a 10\% e translaminar a 3\%. 
Tabela 19. Médias ( \pm EP) de inviabilidade de ovos de Bemisia tabaci biótipo B tratados com extrato aquoso de sementes de nim por vias sistêmica e translaminar, em tomateiro. Experimento 1. Temp.: $22,70 \pm 8,63^{\circ} \mathrm{C}$; UR: $74,25 \pm 24,68 \%$; fotoperíodo natural

\begin{tabular}{lc}
\hline Extratos & Ovos inviáveis (\%) $^{1}$ \\
\hline Sementes de nim (sistêmico a 3\%) & $17,29 \pm 5,67 \mathrm{a}$ \\
Sementes de nim (sistêmico a 10\%) & $16,32 \pm 4,51 \mathrm{ab}$ \\
Sementes de nim (translaminar a 3\%) & $14,69 \pm 5,00 \mathrm{ab}$ \\
Sementes de nim (translaminar a 10\%) & $17,81 \pm 5,90 \mathrm{a}$ \\
Testemunha & $6,97 \pm 3,36 \mathrm{~b}$ \\
\hline
\end{tabular}

${ }^{1}$ Médias seguidas de mesma letra não diferem entre si, pelo teste de Tukey $(P \leq$ $0,05)$.

Tabela 20. Médias ( \pm EP) de inviabilidade de ovos de Bemisia tabaci biótipo B tratados com extrato aquoso de sementes de nim por vias sistêmica e translaminar, em tomateiro. Experimento 2. Temp.: $21,88 \pm 9,11^{\circ} \mathrm{C}$; UR: $72,95 \pm 24,89 \%$; fotoperíodo natural

\begin{tabular}{lc}
\hline Extratos & Ovos inviáveis (\%) \\
\hline Sementes de nim (sistêmico a 3\%) & $14,32 \pm 5,03 a$ \\
Sementes de nim (sistêmico a 10\%) & $15,72 \pm 4,36 a$ \\
Sementes de nim (translaminar a 3\%) & $16,58 \pm 3,77 a$ \\
Sementes de nim (translaminar a 10\%) & $15,27 \pm 9,15 a$ \\
Testemunha & $4,48 \pm 3,91$ b
\end{tabular}

${ }^{1}$ Médias seguidas de mesma letra não diferem entre si, pelo teste de Tukey $(P \leq$ $0,05)$. 


\subsubsection{Efeito ovicida de extratos aquoso e clorofórmico de meliáceas por vias sistêmica e translaminar}

Apenas no tratamento com extrato clorofórmico de ramos de T. pallida por via sistêmica o valor de inviabilidade de ovos da mosca-branca efeito foi maior do que na testemunha (17,63 e 5,26, respectivamente). Nos demais tratamentos, os valores médios variaram entre 12,83 a $15,16 \%$ e não diferiram entre si e tampouco do valor observado na testemunha (Tabela 21).

Tabela 21. Médias ( \pm EP) de inviabilidade de ovos de Bemisia tabaci biótipo B tratados com extratos aquoso de sementes de nim e clorofórmico de ramos de Trichilia pallida por vias sistêmica e translaminar, em tomateiro. Temp.: $22,40 \pm 8,15^{\circ} \mathrm{C}$; UR: $78,00 \pm 20,72 \%$; fotoperíodo natural

\begin{tabular}{lc}
\hline Extratos & Ovos inviáveis (\%) $^{1}$ \\
\hline Ramos de T. pallida (via sistêmica) & $17,63 \pm 5,30 \mathrm{a}$ \\
Ramos de T. pallida (via translaminar) & $15,12 \pm 9,70 \mathrm{ab}$ \\
Sementes de nim (via sistêmica) & $12,83 \pm 2,60 \mathrm{ab}$ \\
Sementes de nim (via translaminar) & $15,16 \pm 9,28 \mathrm{ab}$ \\
Testemunha & $5,26 \pm 2,57 \mathrm{~b}$ \\
\hline
\end{tabular}

${ }^{1}$ Médias seguidas de mesma letra não diferem entre si, pelo teste de Tukey $(\mathrm{P} \leq$ 0,05 ). 


\subsection{Considerações finais}

A mortalidade natural observada nos tratamentos-testemunha na presente pesquisa, em todas as fases imaturas da mosca-branca $B$. tabaci em tomateiro, foi próxima da citada por outros autores, o que permite inferir que a metodologia empregada foi adequada aos objetivos propostos. Foi também confirmada a tendência de maior mortalidade de ninfas pequenas, seguida de ninfas maiores, e menor mortalidade na fase de ovo.

A porcentagem de inviabilidade de ovos nos tratamentos sem aplicação de extratos, nesta pesquisa, variou de 4,48 a 7,85\%, em temperaturas entre 22,40 e $25,50^{\circ} \mathrm{C}$. Estes valores estão de acordo com outros autores que, criando o inseto nas culturas de abóbora, algodão, batata-doce, berinjela, bico-depapagaio, feijão, melão e tomate, verificaram que a inviabilidade de ovos variou de 2 a 11\% em temperaturas entre 20 e $32^{\circ} \mathrm{C}$ (Coudriet et al., 1985b; Drost et al., 1998; Enkegaard, 1993; Nava-Camberos, 2001; Simmons, 1999; Souza \& Vendramim, 2000a e b, 2001; Tsai \& Wang, 1996 e Wang \& Tsai, 1996). Relacionando apenas trabalhos com a cultura do tomate, a variação se manteve em temperaturas de 20 a $26^{\circ} \mathrm{C}$ (Simmons, 1999; Souza \& Vendramim, 2000a e b, 2001 e Wang \& Tsai, 1996).

Já em relação às ninfas de primeiro ínstar, a mortalidade natural (tratamentos sem extratos) variou de 4,12 a 19,58\%, em temperaturas entre 21,25 e $26,35^{\circ} \mathrm{C}$, valores coerentes com os encontrados em literatura, que variaram de 3 a $23 \%$, em temperaturas entre 20 e $26^{\circ} \mathrm{C}$, nas culturas de abóbora, batata-doce, berinjela, bico-de-papagaio, feijão, fumo, melão e tomate (Coudriet et al., 1985b;

Drost et al., 1998; Enkegaard, 1993; Hammad et al., 2000; Liu \& Stansly, 1995a e b; Nava-Camberos, 2001; Simmons, 1999; Souza \& Vendramim, 2000a e b, 2001; Tsai \& Wang, 1996 e Wang \& Tsai). Especificamente na cultura do tomate, a variação encontrada na literatura foi de 2 a $20 \%$ em temperaturas de 20 a $26^{\circ} \mathrm{C}$ (Hammad et al., 2000; Liu \& Stansly, 1995a; Nava-Camberos, 2001; Souza \& Vendramim, 2000a e b, 2001 e Tsai \& Wang, 1996). 
A mortalidade de ninfas de terceiro ínstar variou de 4,11 a 13,63\% em temperaturas entre 26,31 e $28,67^{\circ} \mathrm{C}$, inferior ao valor máximo registrado na literatura (21\%), em temperaturas de 22 a $33^{\circ} \mathrm{C}$, nas culturas de abóbora, algodão, batata-doce, berinjela, bico-de-papagaio, feijão, fumo e tomate (Coudriet et al., 1985b; Drost et al., 1998; Liu \& Stansly, 1995a e b; Natarajan \& Sundaramurthy, 1990 e Tsai \& Wang, 1996). Considerando apenas a cultura de tomate, a mortalidade nesta fase foi de 3 a $8 \%$, em temperaturas próximas a $25^{\circ} \mathrm{C}$ (Liu \& Stansly, 1995a e Tsai \& Wang, 1996). A baixa mortalidade observada por estes autores pode ser atribuída, ao menos em parte, à temperatura adequada para 0 inseto (cerca de $25^{\circ} \mathrm{C}$ ). Outros autores também observaram baixa mortalidade de ninfas de terceiro ínstar quando os experimentos foram conduzidos próximos a $25^{\circ} \mathrm{C}$ em diversas culturas (Natarajan Sundaramurthy, 1990; Liu \& Stansly, 1995a e b eTsai \& Wang, 1996).

$\mathrm{Na}$ primeira fase do trabalho, onde foi aplicado apenas extrato aquoso de sementes de nim, foi observado efeito ninficida pelas vias translaminar, sistêmica e de contato. Com base nos resultados obtidos, entretanto, é difícil afirmar qual dos mecanismos de ação do nim é mais eficiente, uma vez que, em razão das diferentes técnicas empregadas, mesmo com a utilização de uma mesma concentração do extrato, o inseto fica exposto a diferentes quantidades do produto em cada caso.

O efeito de derivados de nim sobre todas as fases de vida de $B$. tabaci tem sido relatado na literatura tanto com a utilização de extratos aquosos de sementes (Coudriet et al., 1985a; Prabhaker et al., 1989 e Souza \& Vendramim, 2000a e b, 2001), como com o emprego do óleo e outros produtos comerciais (Cubillo et al., 1994, 1999; Gómez et al., 1997a; Natarajan \& Sundaramurth, 1990 e Prabhaker et al., 1999).

Apesar dos vários trabalhos demonstrando a eficiência do nim sobre a mosca-branca, pouco era conhecido sobre seu mecanismo de ação quando empregado na planta (ação translaminar e sistêmica) ou diretamente sobre o inseto (ação de contato ou tópica). 
Em aplicações foliares ou quando há imersão das folhas em soluções de nim, o efeito tópico certamente também ocorre, mas a caracterização dos efeitos translaminar e sistêmico é importante porque no campo, nas aplicações convencionais, o produto é pulverizado sobre a folha, o que dificulta o contato direto com o inseto já que este geralmente se abriga sob as folhas.

O efeito translaminar do nim sobre insetos sugadores foi relatado por Verkerk et al. (1998), em trabalho no qual os autores aplicaram o produto comercial numa concentração de 300 ppm sobre folhas de couve e verificaram $100 \%$ de mortalidade ninfal em duas espécies de pulgões.

O efeito sistêmico do nim a sobre mosca-branca já havia sido relatado utilizando-se produtos comerciais em algodoeiro. Coudriet et al. (1985a), fazendo aplicações foliares de um produto comercial à base de extrato de sementes de nim, constataram menor oviposição e mortalidade ninfal mesmo em avaliações feitas aos 14 dias após a aplicação do produto. Prabhaker et al. (1999) observaram o efeito de um produto comercial do nim com $3 \%$ de azadiractina (30 e $60 \mathrm{ppm}$ ) e óleo de sementes de nim (1\%), via solo (aplicação de $10 \mathrm{ml}$ ) e pelas sementes (imersão durante $48 \mathrm{~h}$ ). O produto comercial reduziu a oviposição e causou mortalidade ninfal pelas duas vias de aplicação, enquanto que o óleo de nim só foi eficiente quando aplicado no solo. A maior eficiência via solo foi atribuída à maior persistência do extrato de sementes no solo e, conseqüentemente, maior taxa de translocação das raízes às folhas em comparação com o tratamento de sementes. A translocação do nim pela planta aumenta a sua persistência, tornando esse produto uma boa alternativa de controle para insetos vetores como a mosca-branca.

Além da mosca-branca, o nim já teve seu efeito sistêmico comprovado sobre outros insetos sugadores, na sua maioria, transmissores de vírus fitopatogênicos. Em geral, têm sido observados efeitos em relação ao desenvolvimento e sobrevivência do inseto, bem como na atratividade ou capacidade de transmissão de fitovírus. O modo de aplicação pode ser via solo, imersão das raízes em soluções ou aplicação foliar. As quantidades aplicadas no 
solo têm variado bastante (10 a $150 \mathrm{ml}$ ), mas aparentemente essa variação se deve à diferença no porte das plantas utilizadas, ou seja, quanto menor a planta, menor 0 volume aplicado (Coudriet et al., 1985a; Gill \& Lewis, 1971; Larew, 1988; Nisbet et al., 1993; Prabhaker et al., 1999; Saxena et al., 1984; Weintraub \& Horowitz, 1997 e West \& Mordue (Luntz), 1992).

$\mathrm{Na}$ segunda fase da pesquisa, onde os extratos foram aplicados diretamente sobre as ninfas, utilizando-se extrato aquoso de sementes de nim e extratos orgânico e aquoso de ramos de $T$. pallida, o efeito ninficida do nim foi sempre superior ao dos extratos de T. pallida. Souza \& Vendramim (2000b), comparando os extratos aquosos de ramos de T. pallida, de sementes de nim e de frutos verdes de $M$. azedarach, todos a 3\%, também observaram efeito ninficida superior do nim, próximo de $90 \%$ de mortalidade ninfal, enquanto para os outros dois extratos, a eficiência ficou próxima de 50\%.

A maioria dos experimentos nesta fase foram conduzidos com ninfas jovens devido à maior facilidade para discriminar o efeito dos extratos nessa fase na qual o inseto é mais sensível em comparação a ninfas maiores (Coudriet et al., 1985a; Hammad et al., 2000; Liu \& Stansly, 1995a e b; Prabhaker et al., 1989 e Stansly \& Liu, 1994). Coudriet et al. (1985a) sugerem que a maior sensibilidade das ninfas de estádios iniciais ao nim seja pela ação do produto no sistema neuroendócrino do inseto inibindo a ação dos ecdiesteróides. Pode ser devido a isso que Natarajan \& Sundaramurthy (1990) tenham observado má formação de adultos de mosca-branca após aplicação de nim, o que é característico de disfunções do sistema endócrino dos insetos (Saxena \& Khan, 1985a).

Apenas nos experimentos para observação do efeito de contato dos extratos, é que foram utilizadas ninfas de terceiro ínstar devido à maior facilidade de metodologia, já que as ninfas, nessa fase, além de não apresentarem mobilidade após a marcação, tem alta viabilidade ninfal. Nesse trabalho, a baixa mortalidade natural foi importante, por que, caso contrário, poderia dificultar a análise estatística, dado o número relativamente baixo de repetições utilizadas (20 ninfas por tratamento). 
Com relação a $T$. pallida, apenas os extratos hexânicos não provocaram mortalidade ninfal. Os demais extratos orgânicos testados tiveram efeito semelhante ao do extrato aquoso. É provável que os principais compostos inseticidas de T. pallida tenham afinidade apenas com solventes polares como a água ou de polaridade intermediária como o metanol, etanol e clorofórmio. Devido ao efeito semelhante causado por estes extratos, acredita-se que são vários os compostos químicos envolvidos na ação inseticida de T. pallida sobre a moscabranca.

Roel et al. (2000), comparando o efeito de extratos orgânicos de ramos e folhas de T. pallida sobre lagartas de S. frugiperda, também observaram que os extratos obtidos com solventes de polaridade intermediária foram mais efetivos do que aqueles provenientes de solventes mais apolares. A maior eficiência de derivados vegetais oriundos da extração com solventes de polaridade intermediária em relação aos mais apolares têm sido relatada para outras espécies vegetais e outros insetos (Ascher et al. ,1984; Cubillo et al.; 1997 e Saito et al., 1989).

$\mathrm{Na}$ terceira fase da pesquisa, onde foi comparado o efeito ninficida por via translaminar, sistêmica e de contato do extrato aquoso de sementes de nim e dos extratos aquoso e clorofórmico de ramos de T. pallida, o primeiro extrato, a 1\%, causou aumento de mortalidade em comparação à testemunha em todas as formas de aplicação, enquanto os extratos de T. pallida, nessa mesma concentração, não apresentaram ação translaminar. Nos testes de avaliação das ações sistêmica e de contato, embora os valores com os extratos aquoso e clorofórmico, a 1\%, tenham sido superiores à testemunha, somente o extrato aquoso diferiu da testemunha e apenas no segundo experimento para cada um dos efeitos.

Os experimentos relacionados à ação ovicida foram motivados principalmente pelos resultados promissores de Souza \& Vendramim (2000b) com T. pallida cujos efeitos haviam superado até mesmo o efeito ovicida do nim. A partir destes trabalhos, surgiram novas questões, como, por exemplo, o possível efeito da idade do ovo sobre o efeito ovicida e se, além de um efeito de contato, 
haveria também efeitos sistêmico e translaminar, o que é um importante subsídio para se estabelecer a técnica de aplicação do extrato.

Em relação ao nim, os resultados obtidos evidenciaram que a idade do ovo não influencia o efeito ovicida do nim. Byrne et al. (2000) observaram que o ovo da mosca-branca Trialeurodes vaporariorum (Westwood) absorve água continuamente da planta e que cerca de $50 \%$ de sua massa corresponde à água absorvida durante o período de incubação. Sendo assim, nesse experimento, o efeito semelhante observado nas diferentes idades avaliadas pode ser devido à absorção de água nas mesmas quantidades durante todo o período de incubação.

Buckner et al. (2002) constataram que o pedicelo do ovo de B. tabaci biótipo $B$, que é uma extensão do córion, é responsável pela absorção e condução de água e solutos do citoplasma da célula da planta hospedeira para o ovo, quando o pedicelo está inserido nas células da epiderme.

$\mathrm{Na}$ comparação do extrato aquoso de sementes de nim com os extratos aquoso e clorofórmico de ramos de T. pallida, o nim superou estes dois extratos. Souza \& Vendramim (2000b), entretanto, observaram que o extrato aquoso de ramos de $T$. pallida provocaram mais mortalidade do que o nim. Diferenças como essa são esperadas no estudo de plantas inseticidas, pois a quantidade dos compostos inseticidas numa mesma espécie de planta é influenciada por fatores climáticos e genéticos e pelo local de coleta da planta (Isman, 1997 e Wewetzer, 1998). Com relação ao nim, para se possibilitar a comparação do efeito inseticida entre diferentes trabalhos é necessária a quantificação do teor de azadiractina, principal composto inseticida presente nessa planta, no material utilizado.

Considerando-se os diversos experimentos realizados na presente pesquisa, constatou-se que o extrato aquoso de sementes de nim foi mais eficiente que os extratos aquoso e orgânicos de ramos de T. pallida.

A maior eficiência do nim, de certa forma, já era esperada, visto que essa planta é conhecida há muito tempo pelos excelentes resultados no controle de diversos insetos-praga (Jacobson, 1989 e Martinez, 2002). Entretanto, um fator 
que estimula a pesquisa de novas plantas inseticidas é que a molécula de azadiractina é complexa, o que impede sua síntese purificada em escala comercial. No gênero Trichilia spp., existem várias espécies de plantas, além de $T$. pallida, com efeito inseticida reconhecido sobre lepidópteros (Xie et al., 1994 e Bogorni, 2003), tendo já sido identificados nesse gênero vários limonóides com propriedades inseticidas (Inada et al., 1994; Kubo \& Klocke, 1982; Mikolajczak \& Reed, 1987; Nakatani et al., 1981; Simmonds et al., 2001 e Xie et al., 1994).

Pesquisas desenvolvidas no Laboratório de Plantas Inseticidas da ESALQ/USP já tinham demonstrado o efeito ninficida de extratos aquosos de $T$. pallida em relação à mosca-branca (Souza \& Vendramim, 2000a e b, 2001). Assim, a presente pesquisa foi importante para se comparar o efeito de extratos dessa planta e os extratos de nim, bem como avaliar os mecanismos de ação quando os extratos são aplicados em tomateiro. Os resultados evidenciaram que os extratos de nim foram mais efetivos que os de $T$. pallida nos três modos de aplicação testados.

Apesar do efeito limitado dos extratos de ramos de T. pallida sobre ninfas de $B$. tabaci, ao menos em comparação com o extrato de nim, este trabalho comprovou a ação do extrato aquoso daquela espécie por vias sistêmica e de contato. Além disso, com base nas tendências observadas, é possível que em concentrações maiores seja constatado também efeito por via translaminar, além de maior efeito sistêmico e tópico.

Isso abre boas perspectivas para estudos mais aprofundados para uso de extratos de $T$. pallida no controle de pragas, bem como para se tentar identificar os compostos responsáveis por essa ação inseticida. 


\section{CONCLUSÕES}

Com base nos resultados obtidos com o uso de extratos aquosos e orgânicos de Trichilia pallida e aquosos de Azadirachta indica no controle da mosca branca Bemisia tabaci (Genn., 1889) biótipo B, foram estabelecidas as seguintes conclusões:

- O extrato aquoso de sementes de nim tem efeito ninficida pelas vias translaminar, sistêmica e de contato em concentrações de 1; 0,5 e $0,3 \%$, respectivamente.

- Os extratos aquoso, clorofórmico, metanólico e etanólico de ramos de $T$. pallida a $5 \%$ reduzem a sobrevivência da fase ninfal do inseto, enquanto o extrato hexânico não apresenta ação inseticida.

- Os extratos aquoso e clorofórmico de ramos de T. pallida não têm efeito ninficida pelas vias translaminar, sistêmica e de contato em concentrações de 1; 0,5 e 0,3\%, respectivamente.

- A idade do ovo de mosca-branca não influencia o efeito ovicida de extratos aquosos de sementes de nim.

- A viabilidade dos ovos de mosca-branca é diminuída pela ação translaminar e sistêmica do extrato aquoso de sementes de nim. 


\section{REFERÊNCIAS BIBLIOGRÁFICAS}

ABRAHAM, C.C.; AMBIKA, B. Effect of leaf and kernel extracts of neem on moulting and vitellogenesis in Dysdercus cingulatus Fabr. (Heteroptera: Pyrrhocoridae). Current Science, v.48, n.48, p.554-556, 1979.

ALEXANDRE, M.A.V.; NORONHA, A.B.; VICENTE, M. Ação de inibidores naturais sobre duas viroses do feijoeiro: mosaico dourado e mosaico do fumo "strain" adaptado às leguminosas. Fitopatologia Brasileira, v.12, n.3, p.202-205, 1987.

ANANTHAKRISHNAN, T.N. Host correlated variation in Trialeurodes rara Singh and Bemisia tabaci (Genandius) (Aleyrodidae: Homoptera: Insecta). Current Science, v.45, p.223-225, 1976.

ASCHER, K.R.S.; ELIYAHU, M.; NEMNY, N.E.; MEISNER, J. Neem seed kernel extract as an inhibitor or growth and fecundity in Spodoptera littoralis. In: INTERNATIONAL NEEM CONFERENCE, 2., Ruischholzhauzen, 1983. Natural Pesticides from the neem tree (Azadirachta indica A. Juss) and other tropical plants. Eschborn: GTZ Press, 1984. p. 331-344.

ASIATICO, J.M.; ZOEBISCH, T.G. Control de mosca blanca Bemisia tabaci (Gennadius) en tomate com insecticidas de origen biologico y quimico. Manejo Integrado de Plagas, v.24/25, p.1-7, 1992. 
AZAB, A.K.; MEGAHED, M.M.; EL-MIRSAWI, H.D. Studies on Bemisia tabaci (Gennadius) (Hemiptera-Homoptera: Aleyrodidae). Bulletin of Society Entomological of Egypt, v.53, p.339-352, 1969.

BASU, A.N. Bemisia tabaci (Gennadius): crop pest and principal whitefly vector of plant viruses. New Delhi: Westview Press, 1995. 183 p.

BELLOWS JUNIOR, T.S.; PERRING, T.M.; GILL, R.J.; HEADRICK, D.H. Description of a species of Bemisia (Homoptera: Aleyrodidae). Annals of the Entomological Society of America, v.87, n.2, p.195-206, 1994.

BERLING, M.J. Host plant resistance to Bemisia tabaci. Agriculture Ecosystems \& Environment, v.17, p.69-82, 1986.

BETHKE, J.A.; PAINE, T.D.; NUESSLY, G.S. Comparative biology, morphometrics, and development of two populations of Bemisia tabaci (Homoptera: Aleyrodidae) on cotton and poinsettia. Annals of the Entomological Society of America, v.84, n.4, p.407-411, 1991.

BINK-MOENEM, R.M.; MOUND, L.A. Whiteflies: diversity, byosystematics and evolutionary patterns. In: GERLING, D. (Ed.). Whiteflies: their bionomics, pests status and management. Winborne: Intercept, 1990. cap.1, p.1-12.

BLUA, M.J.; YOSHIDA, H.A.; TOSCANO, N.C. Oviposition preference of two Bemisia species (Homoptera: Aleyrodidae). Environmental Entomology, v.24, n.1, p. 88-93, 1995. 
BOGORNI, P.C. Efeito de extratos aquosos de Trichilia spp. sobre o desenvolvimento de Spodoptera frugiperda (J.E. Smith) em milho. Piracicaba, 2003. 65p. Tese (Doutorado) - Escola Superior de Agricultura "Luiz de Queiroz", Universidade de São Paulo.

BROWN, J.K. Current status of Bemisia tabaci as a plant pest and virus vector in agroecosystems worldwide. FAO Plant Protection Bulletin, v.42, n.1/2, p.3-33, 1994.

BROWN, J.K.; FROHLICH, D.R.; ROSELL, R.C. The sweetpotato or silverleaf whiteflies: Biotypes of Bemisia tabaci or a species complex? Annual Review of Entomology, v.40, p.511-534, 1995.

BRUNHEROTTO, R.; VENDRAMIM, J.D. Bioatividade de extratos aquosos de Melia azedarach L. sobre o desenvolvimento de Tuta absoluta (Meyrick). Neotropical Entomology, v.30, n.3, p.455-459, 2001.

BUCKNER, J.S.; FREEMAN, T.P.; RUUD, R.L.; CHU, C.; HENNEBERRY, T.J. Characterization and functions of the whitefly egg pedicel. Archives of Insect Biochemistry and Physiology, v.49, p.22-33, 2002.

BUTLER JUNIOR, G.D.; WILSON, F.D. Activity of adult whiteflies (Homoptera: Aleyrodidae) withing plantings of different cotton strains and cultivars as determined by sticky-trap catches. Journal of Economic Entomology, v.79, p.1137-1140, 1984.

BUTLER JUNIOR, G.D.; HENNEBERRY, T.J.; CLAYTON, T.E. Bemisia tabaci (Homoptera: Aleyrodidae): development, oviposition, and longevity in relation to temperature. Annals of the Entomological Society of America, v.76, n.2, p.310-313, 1983. 
BYRNE, D.N.; BELLOWS JUNIOR, T.S. Whitefly biology. Annual Review of Entomology, v.36, p.431-457, 1991.

BYRNE, D.N.; MILLER, W.B. Carbohydrate and amino acid composition of phloem sap and honeydew produced by Bemisia tabaci. Journal of Insect Physiology, v.36, n.6, p.433-439, 1990.

BYRNE, D.N.; COHEN, A.C.; DRAEGER, E.A. Water uptake from plant tissue by the egg pedicel of the greenhouse whitefly, Trialeurodes vaporariorum (Westwood) (Homoptera: Aleyrodidae). Canadian Journal of Zoology, v.68, p.1193-1195, 1990.

CABALLERO, R. Clave de campo para imaduros de moscas blancas de Centroamérica (Homoptera: Aleyrodidae). Zamorano: Escuela Agricola Panamericana, 1994. 4 p.

CHESSIN, M. Is there a plant interferon? The Botanical Review, v.47, p.1-28, 1983.

COHEN, S.; DUFFUS, J.E.; LIU, H.Y. A new Bemisia tabaci biotype in the Southwestern United States and its role in silverleaf of squash and transmission of lettuce infectious yellows virus. Phytopatology, v.82, n.1, p.86-90, 1992.

COSTA, H.S.; BROWN, J.K. Variation in biological characteristcs and sterase patterns among populations of Bemisia tabaci Genn. and the association of one population with silverleaf symptom induction. Entomologia Experimentalis et Applicata, v.61, p.211-219, 1991. 
COSTA, H.S.; BROWN, J.K.; BYRNE, D.N. Life history traits of the whitefly, Bemisia tabaci (Homoptera: Aleyrodidae) on six virus-infected or healthy plant species. Environmental Entomology, v.20, n.4, p.1102-1107, 1991.

COSTA, H.S.; ULLMAN, D.E.; JOHNSON, M.W.; TABASHNIK, B.E. Squash silverleaf symptoms induced by immature, but not adult, Bemisa tabaci. Phytopathology, v.83, n.7, p.763-766, 1993.

COUDRIET, D.L.; PRABHAKER, N.; MEYERDIRK, D.E. Sweetpotato whitefly (Homoptera: Aleyrodidae): Effects of neem-seed extract on oviposition and immature stages. Environmental Entomology, v.14, n.6, p.776-779, 1985a.

COUDRIET, D.L.; PRABHAKER, N.; KISHABA, A.N.; MEYERDIRK, D.E. Variation in developmental rate on different hosts and overwintering of the sweetpotato whitefly, Bemisia tabaci (Homoptera: Aleyrodidae). Environmental Entomology, v.14, p.516-559, 1985b.

CUBILLO, D.; SANABRIA,G.; HIJE,L. Mortalidade de adultos de Bemisia tabaci com extractos de hombre grande (Quassia amara). Manejo Integrado de Plagas, v.45, p.25-29, 1997.

CUBILLO, D.; SANABRIA,G.; HIJE,L. Evaluación de la repelencia y mortalidad causada por inseticidas comerciales y extractos vegetales sobre Bemisia tabaci. Manejo Integrado de Plagas, v.53, p.65-71, 1999.

CUBILLO, D.; QUIJIJE, R.; LARRIVA, W.; CHACÓN, A.; HILJE, L. Evaluación de la repelencia de varias substancias sobre la mosca blanca Bemisia tabaci (Homoptera: Aleyrodidae). Manejo Integrado de Plagas, v.33, p.2628, 1994. 
DE BARRO, P.J. Bemisia tabaci biotype B: a review of its biology, distribution and control. Camberra: CSIRO, 1995. 58 p.

DORN, A.; RADEMACHER, J.M.; SEHN, E. Effects of azadirachtin on the moulting cycle, endocrine system, and ovaries in last-instar larvae of the milkweed bug, Oncopeltus fasciatus. Journal of Insect Physiology, v.32, n.3, p.231-238, 1986.

EICHELKRAUT, K.; CARDONA, C. Biologia, cria massal y aspectos ecológicos de la mosca blanca Bemisia tabaci (Gennadius) (Homoptera: Aleyrodidae), como plaga del frijol común. Turrialba, v.39, n.1, p.51-55, 1989.

ENKEGAARD, A. The poinsettia strain of the cotton whitefly, Bemisia tabaci (Homoptera: Aleyrodidae), biological and demographic parameters on poinsettia (Euphorbia pulcherrima) in relation to temperature. Bulletin of the Entomological Research, v.83, p.535-546, 1993.

FERRI, P.H. Química de produtos naturais: métodos gerais. In: DI STASI, L.C. Plantas medicinais: arte e ciência; um guia de estudo interdisciplinar. São Paulo: UNESP, 1996. cap.10, p.129-156.

FRANÇA F.H.; VILLAS BOAS, G.L.; BRANCO, M.C. Ocorrência de Bemisia argentifolii Bellows \& Perring (Homoptera: Aleyrodidae) no Distrito Federal. Anais da Sociedade Entomológica do Brasil, v.25, n.2, p. 369-372, 1996.

GALLO, D.; NAKANO, O.; SILVEIRA NETO, S.; CARVALHO, R.P.L.; BAPTISTA, G.C. de; BERTI FILHO, E.; PARRA, J.R.P.; ZUCCHI, R.A.; ALVES, S.B.; VENDRAMIM, J.D.; MARCHINI, L.C.; LOPES, J.R.S.; OMOTO, C. Entomologia agrícola. Piracicaba: FEALQ, 2002. 920p. (Biblioteca de Ciências Agrárias Luiz de Queiroz, 10). 
GERLING, D. Una reinterpretación sobre las moscas blancas. Manejo Integrado de Plagas, v.63, p.13-21, 2002.

GERLING, D.; HOROWITZ, A.R.; BAUMGAERTNER, J. Autecology of Bemisia tabaci. Agriculture, Ecosystems \& Environment, v.17, p.5-19, 1986.

GILL, J.S.; LEWIS, C.T. Systemic action of an insect feeding deterrent. Nature, v.232, p.402-403, 1971.

GÓMEZ, P.; CUBILLO, D.; MORA, G.A.; HILJE, L. Evaluación de possibles repelentes de Bemisia tabaci: I. Productos comerciales. Manejo Integrado de Plagas, v.46, p.9-16, 1997a.

GÓMEZ, P.; CUBILLO, D.; MORA, G.A.; HILJE, L. Evaluación de possibles repelentes de Bemisia tabaci: II. Extractos vegetables. Manejo Integrado de Plagas, v.46, p.17-25, 1997b.

GOFFREDA, J.C.; MUTSCHLER, M.A.; AVE, D.A.; TINGEY, W.M.; STEPHENS, J.C. Aphid deterrence by glucose esters in the glandular exudate of the wild tomato, Lycopersicon pennelli. Journal of Chemical Ecology, v.15, p.2135-2147, 1989.

GOVINDACHARI, T.R.; SURESH, G.; GOPALAKRISHNAN, G.; WESLEY, S.D. Insect antifeeding and growth regulating activities of neem seed oil - the role of major tetranortriterpenoids. Journal of Applied Entomology, v.124, p.287-291, 2000.

GRAINGE, M.; AHMED. S. Handbook of plants with pest control properties. New York: John Wiley, 1988. 470 p. 
GRIFFITHS, D.C.; GREENWAY, A.R.; LLOYD, S.L. The influence of repellent materials and aphid extracts on settling behaviour and larviposition of Myzus persicae (Sulzer) (Hemiptera: Aleyrodidae). Bulletin of Entomological Research, v. 68, p.613-619, 1978.

HAMMAD, E.M.A.; NEMER, N.M.; HAWI, Z.K.; HANNA, L.T. Responses of the sweetpotato whitefly, Bemisia tabaci, to the chinaberry tree (Melia azedarach L.) and its extracts. Annals of Applied Biology, v.137, p.79-88, 2000.

HEYDE, J.V.D.; SAXENA, R.C.; SCHMUTTERER, H. Neem oil and neem extracts as potential insecticide for control of hemipterous rice pests. In: INTERNATIONAL NEEM CONFERENCE, 2., Eschborn, 1984. Proceedings. Eschborn: Agency for Technical Coorporation, 1984. p.377390.

HILJE, L. Metodología para el estudio y manejo de moscas blancas y geminivirus. Turrialba: CATIE, Unidad de Fitoprotectión, 1996. 133p.

HOFFMAN C.J.; BYRNE, D.N. Effects of temperature and photoperiod upon adult eclosion of the sweetpotato whitefly Bemisia tabaci. Entomologia Experimentalis et Applicata, v.42, p.139-143, 1986.

HOROWITZ, A.R.; GERLING, D. Seasonal variation of sex ratio in Bemisia tabaci on cotton in Israel. Environmental Entomology, v.21, n.3, p.556559, 1992. 
HUANG, R.C.; ZHOU, J.B.; SUENAGA, H.; TAKEZAKI, K.; TADERA, K.; NAKATANI, M. Insect antifeeding property of limonoids from Okinawan and chinese Melia azedarach L., and from chinese Melia toosendan (Meliaceae). Bioscience of Biotechnolgy and Biochemistry, v.59, n.9, p.1755-1757, 1995.

HUNTER, W. B.; ULLMAN, D. E. Effects of the neem product, RD-repelin, on setting behaviour and transmission of zuchini yellow mosaic virus by the pea aphid, Acyrthosiphon pisum (Harris) (Homoptera: Aphididae). Annals of Applied Biology, v.120, p.9-15, 1992.

INADA, A.; KONISHI, M.; MURATA, H.; NAKANISHI, T. Structures of a new limonoid and a new triterpenoid derivative from pericarps of Trichilia connaroides. Journal of Natural Products, v.57, n.10, p.1446-1449, 1994.

ISMAN, M.B. Neem and other botanical insecticides: barriers to commercialization. Phytoparasitica, v.25, n.4, p.339-344, 1997.

JACOBSON, M. Botanical pesticides - past, present, and future. In: ARNASAN, J.T.; PHILOGĖNE, B.J.R.; MORAND, P. (Ed.). Insecticides of plant origin. Washington: American Chemical Society, 1989. p.1-10. (ACS. Symphosium Séries, 387).

KAYS, S.J.; SEVERSON, R.F.; NOTTINGHAM, S.F.; CHALFNAT, R.B.; CHORTYK, O. Possible biopesticide from petunia for the control of the sweetpotato whitefly (Bemisia tabaci) on vegetable crops. Proceedings of the Florida State for Horticultural Society, v.107, p.163-167, 1994. 
KING, R.R.; SINGH, R.P.; BOUCHER, A. Variation in sucrose esters from the type $b$ glandular trichomes of certain wild potato species. American Potato Journal, v.64, p.529-534, 1987.

KLEIN, R.M. As plantas meliáceas. Flora llustrada Catarinense. v.1, p.40-46, 1984.

KOUL, O.; ISMAN, M.B.; KETKAR, C.M. Properties and uses of neem, Azadirachta indica. Canadian Journal of Botany, v.68, n.1, p.1-11, 1990.

KUBO, I.; KLOCKE, J.A. An insect growth inhibitor from Trichilia roka (Meliaceae). Experientia, v.38, p.639-640, 1982.

LAGUNES T., A., RODRÍGUEZ H., C. Búsqueda de tecnología apropiada para el combate de plagas del maíz almacenado en condiciones rústicas. Chapingo: CONACYT, 1989. 150p.

LAREW, H.G. Limited occurrence of foliar-, root-, and seed-applied neem seed extract toxin in untreated plant parts. Journal of Economic Entomology, v.81, n.2, p.593-598, 1988.

LAREW, H.G.; LOCKE, J.C. Repellency and toxicity of a horticultural oil against whiteflies on crysanthemum. Hortscience, v.25, n.11, p.1406-1407, 1990.

LAREW, H.G.; KNODEL-MONTZ, J.J.; WEBB, R.E.; WARTHEN, J.D. Liriomyza trifolii (Burgess) (Diptera: Agromyzidae) control on Chrysanthemum by neem seed extract applied to soil. Journal of Economic Entomology, v.81, n.2, p.593-598, 1988. 
LESKOVAR, D.I.; BOALES, A.K. Azadirachtin. Potential use for controlling lepidopterous insects and increasing marketability of cabbage. Hortscience, v.31, n.3, p.405-409, 1996.

LIU, T.X.; STANSLY, P.A. Deposition and bioassay of insecticides applied by leaf dip and spray tower against Bemisia argentifolii (Homoptera: Aleyrodidae). Pesticide Science, v.44, p.317-322, 1995b.

LIU, T.X.; STANSLY, P.A. Toxicity of biorational insecticides to Bemisia argentifolii (Homoptera: Aleyrodidae) on tomato leaves. Journal of Economic Entomology, v.88, n.3, p.564-568, 1995a.

LIU, T.X.; STANSLY, P.A. Life history of Bemisia argentifolii (Homoptera: Aleyrodidae) on Hibiscus rosa-sinensis (Malvaceae). Florida Entomologist, v.81, n.3, p.437-445, 1998.

LOURENÇÃO, A.L.; NAGAI, H. Surtos populacionais de Bemisia tabaci no Estado de São Paulo. Bragantia, v.53, n.1, p.53-59, 1994.

MARKHAM, P.G.; BEDFORD, I.D.; LIU, S.; FROLICH, D.F.; ROSELL, R.; BROWN, J.K. The transmission of geminivirus by biotypes of Bemisia tabaci (Gennadius). In: GERLING, D.; MAYER, R.T. (Ed.). Bemisia: taxonomy, biology, damage, control and management. Andover: Intercept, 1995. cap.5, p.69-76.

MARTIN, J.H. An identification guide to common whitefly pest species of the world (Homoptera: Aleyrodidae). Tropical Pest Management, v.33, n.4, p.298-322, 1987. 
MARTINEZ, S.S. O Nim - Azadirachta indica: natureza, usos múltiplos, produção. Londrina: Instituto Agronômico do Paraná, 2002. 142p.

MATOS, F.J. A. Introdução à fitoquímica experimental. Fortaleza: Edições UFC, 1988. 128p.

MELO, P.C.T. Mosca branca ameaça produção de hortaliças. Campinas: ASGROW do Brasil Sementes, 1992. 2p.

MIKOLAJCZAK, K.L.; REED, D.K. Extractives of seeds of the Meliaceae: effects on Spodoptera frugiperda (J.E. Smith), Acalymma vittatum (F.), and Artemia salina Leach. Journal of Chemical Ecology, v.13, n.1, p.99-111, 1987.

MOHANTY, A.K.; BASU, A.N. Effect of host plants and seasonal factors on intraespecific variations in pupal morphology of the whitefly vector, Bemisia tabaci (Gennadius) (Homoptera: Aleyrodidae). Journal of Entomological Research, v.10, p.19-26, 1986.

MORDUE (LUNTZ), A.J.; BLACKWELL, A. Azadirachtin: an update. Journal of Insect Physiology, v.39, p.903-924, 1993.

MORILO, F.E.; MARCANO, R.V.B. Estudio del desarrollo de la mosca blanca en diferentes genotipos de tomate. Agronomia Tropical, v.47, n.3, p.271286, 1997.

MUNAKATA, K. Insect feeding deterrent in plants. In: SHOREY, H.H.; MCKELVEY JUNIOR, J.J. (Ed.). Chemical control of insect behavior; theory and application. New York: John Wiley, 1977. p.95. 
MURRANT, A.F.; RACCAH, B.; PIRONE, I.P. Transmission by vectors. In: MILNE, R.G . (Ed.). The plant viruses: the filamentous plant viruses. New York: Plenum Press, 1988. p.237-265.

NAKATANI, M.; JAMES, J.C.; NAKANISHI, K. Isolation and structures of trichilins, antifeedants against the Southern army worm. Journal of the American Chemical Society, v.103, n.5, p.1228-1230, 1981.

NARDO, E.A.B. de. Triagem de substâncias como interferentes na aquisição e inoculação de vírus de plantas por insetos vetores. Campinas, 1989. 96p. Tese (Doutorado) - Instituto de Biologia. Universidade Estadual de Campinas.

NARDO, E.A.B. de; COSTA, A.S. Extratos de Melia azedarach e óleo vegetal reduzem disseminação no mosaico dourado do feijoeiro. Fitopatologia Brasileira, v.15, n.2, p.145, 1990.

NARDO, E.A.B. de; COSTA. A.S.; LOURENÇÃO, A.L. Melia azedarach extract as an antifeedant to Bemisa tabaci (Homoptera: Aleyrodidae). Florida Entomologist, v.80, n.1, p.92-94, 1997.

NATARAJAN, K.; SUNDARAMURTHY, V.T. Effect of neem oil on cotton whitefly (Bemisia tabaci). Indian Journal of Agricultural Sciences, v.60, n.4, p.290-291, 1990.

NAVA-CAMBEROS, U.; RILEY, D.G.; HARRIS, M.K. Temperature and host plant effects on development, survival, and fecundity of Bemisia argentifolii (Homoptera: Aleyrodidae). Environmental Entomology, v.30, n.1, p.5563, 2001. 
NEAL JUNIOR, J.W.; BUTA, J.G.; PITTARELLI, W.G.; LUSBY, W.R.; BENTZ, J.A. Novel sucrose esters from Nicotiana gossei: Effective biorational against selected horticultural insect pests. Journal of Economic Entomology. v.87, n.6, p.1600-1607, 1994.

NISBET, A.J.; WOODFORD, J.A.T.; STRANG, R.H.C. The effects of azadirachtin on the acquisition and inoculation of potato leafroll virus by Myzus persicae. Crop Protection, v.15, n.1, p.9-14, 1996.

NISBET, A.J.; WOODFORD, J.A.T.; STRANG, R.H.C.; CONRDLY, J.D. Systemic antifeeding effects of azadirachtin on the peach-potato aphid Myzus persicae. Entomologia Experimentalis et Applicata, v.68, p.87-98, 1993.

OHNESORGE, B.; RAPP, G. Monitoring Bemisia tabaci: a review. Agriculture, Ecosystems and Environment, v.17, p.21-28, 1986.

OLIVEIRA, M.R.V.; HENNEBERRY, T.J.; ANDERSON, P. History, current status, and collaborative research projects for Bemisia tabaci. Crop Protection, v.20, p.709-723, 2001

PAULSON, G.S.; BEARDSLEY, J.W. Whitefly (Hemiptera: Aleyrodidae) egg pedicel insertion into host plant stomata. Annals of the Entomological Society of America, v.78, n.4, 506-508, 1985.

PATEL, H.M.; JHALA, R.C.; PANDYA, H.V.; PATEL, C.B. Biology of whitefly (Bemisia tabaci) on okra (Hibiscus esculentus). Indian Journal of Agricultural Science, v.62, n.7, p.497-499, 1992. 
PÄTS, P.; ISMAN, M.B. Effect of neem on adult longevity, oviposition and larval development of the cabbage fly, Delia radicum (L.) (Dip., Anthomyidae). Journal of Applied Entomology, v.122, p.125-127, 1998.

PAULSON, G.S.; BEARDSLEY, J.W. Whitefly (Hemiptera: Aleyrodidae) egg pedicel insertion into host plant stomata. Annals of the Entomological Society of America, v.78, n.4, p.506-509, 1985.

PEREIRA, R.A.S.; MENEZES JUNIOR; A.O.; SUGAWARA, L.M. Criação da mosca-branca Bemisia tabaci (Gennadius) (Hemiptera: Aleyrodidae) em folhas enraizadas de soja (Glycine $\max$ (L.) Merr.). Semina, v.17, n.1, p.4548, 1996.

PERRING, T.M.; COOPER, A.D.; KAZMER, D.J. Identification of the poinsettia strain of Bemisia tabaci (Homoptera: Aleyrodidae) on brocoli by electrophoresis. Journal of Economic Entomology, v.85, p.1278-1284, 1992.

PERRING, T.M.; COOPER, A.D.; KASMER, D.J.; SHIELDS, C.; SHIELDS, J. New strain of sweetpotato whitefly invades California vegetables. California Agriculture, v.45, p.10-12, 1991.

PERRING, T.M.; COOPER, A.D.; RODRIGUEZ, R.J.; FARRAR, C.A.; BELLOWS JUNIOR, T.S. Identification of a whitefly species by genomic and behavioral studies. Science, v.259, p.74-77, 1993.

POLLARD D. G. Feeding habitats of the cotton whitefly, Bemisia tabaci Genn. (Homoptera: Aleyrodidae). Annals of Applied Biology, v.43, n.4, p.664671, 1955. 
POWELL, D.A.; BELLOWS JUNIOR, T.S. Adult longevity, fertility and population growth rates for Bemisia tabaci (Genn.) (Hom., Aleyrodidae) on two host plant species. Journal of Applied Entomology, v.113, p.68-78, 1992.

PRABHAKER, N.; TOSCANO, N.C.; COUDRIET, D.L. Susceptibility of the immature and adult stages of the sweetpotato whitefly (Homoptera: Aleyrodidae) to selected insecticides. Journal of Economic Entomology, v.82, n.4, p.983-988, 1989.

PRABHAKER, N.; TOSCANO, N.C ; COUDRIET, D.L. Comparison of neem, ureia, and amitraz as oviposition supressants and larvicides against Bemisia argentifolii (Homoptera: Aleyrodidae). Journal of Economic Entomology, v.92, n.1, p.40-46, 1999.

PRABHAKER, N.; TOSCANO, N.C.; HENNEBERRY, T.J. Evaluation of insecticide rotations and mixtures as resistance management strategies for Bemisia argentifolii (Homoptera: Aleyrodidae). Journal of Economic Entomology, v.91, n.4, p.820-826, 1998.

PURI, S.N.; BHOSLE, B.B.; ILYAS, M.; BUTLER JUNIOR., G.D.; HENNEBERRY, T.J. Detergents and plant-derived oils for control of the sweetpotato whitefly on cotton. Crop Protection, v.13, n.1, p.45-48, 1994.

QUEIROZ PAULO, M. Estudo fitoquímico da folhas de Virola surinamensis (Rol.) Warb. e Osteopholeum plastyspermum (A. DC.) Smith. Campinas, 1983. 120p. Dissertação (Mestrado) - Instituto de Química. Universidade Estadual de Campinas. 
RODRIGUEZ H, C.; VENDRAMIM, J.D. Avaliação da bioatividade de extratos aquosos de Meliaceae sobre Spodoptera frugiperda (J.E. Smith). Revista de Agricultura, v.72, n.3, p.305-318, 1997.

RODRIGUEZ H., C.; VENDRAMIM, J.D. Toxicidad de extractos acuosos de Meliaceae en Spodoptera frugiperda (Lepidoptera: Noctuidae). Manejo Integrado de Plagas, v.42, p.14-22, 1996.

ROEL, A.R.; VENDRAMIM, J.D. Desenvolvimento de Spodoptera frugiperda (J.E.Smith) em genótipos de milho tratados com extrato acetato de etila de Trichilia pallida (Swartz). Scientia Agricola, v.58, p.581-586, 1999.

ROEL, A.R.; VENDRAMIM, J.D.; FRIGHETTO, R.T.S.; FRIGHETTO, N. Efeito do extrato acetato de etila de Trichilia pallida Swartz (Meliaceae) no desenvolvimento e sobrevivência da lagarta-do-cartucho. Bragantia, v.59, n.1, p.53-58, 2000.

SABILLON, A.; BUSTAMANTE, M. Evaluación de extractos botánicos para el control de plagas del tomate (Lycopersicom sculentum Mill.). CEIBA, v.36, p.179-187, 1995.

SAITO, M.L.; OLIVEIRA, F.; FELL, D.; TAKEMATSU, A.P.; JOCYS, T.; OLIVEIRA, L.J. Verificação da atividade inseticida de alguns vegetais brasileiros. Arquivos do Instituto Biológico, v.56, n.1/2, p.53-59, 1989.

SALAS, J.; MENDONZA, O. Biology of the sweetpotato whitefly (Homoptera: Aleyrodidae) on tomato. Florida Entomologist, v.78, n.1, p.154-160, 1995. 
SAXENA, R.C.; BONCODIN, M.E.M. Effect of neem seed bitters (NSB) on green leafhopper $(\mathrm{GLH})$ feeding. International Rice Research Newsletter, v.13, n.1, p.27, 1988.

SAXENA, R.C.; EPINO, P.B. Azadirachtin as growth inhibitor of leafhopper and planthopper pests of rice. In: INTERNATIONAL NEEM CONFERENCE, 2., Ruischholzhauzen, 1983. Natural pesticides from the neem tree (Azadirachta indica A. Juss) and other tropical plants. Eschborn: GTZ Press, 1984. p. 25-28.

SAXENA, R.C.; KHAN, Z.R. Effect of neem oil on survival of Nilaparvata lugens (Homoptera: Delphacidae) and on grassy stunt and ragged stunt virus transmission. Journal of Economic Entomology, v.78, n.3, p.647-651, $1985 a$.

SAXENA, R.C.; KHAN, Z.R. Electronically recorded disturbances in feeding behavior of Nephotettix virescens (Homoptera: Cicadellidae) on neem oiltreated rice plants. Journal of Economic Entomology, v.78, n.1, p.222226, 1985b.

SAXENA, R.C.; JUSTO JUNIOR, H.D.; EPINO, P.B. Evaluation and utilization of neem cake against the rice brown planthopper Nilaparvata lugens (Homoptera: Delphacidae). Journal of Economic Entomology, v. 77, n.2, p.502-507, 1984.

SAXENA, R.C.; KHAN, Z.R.; BAJET, N.B. Reduction of tungro virus transmission by Nephotettix virescens (Homoptera: Cicadellidae) in neem cake-treated rice seedlings. Journal of Economic Entomology. v. 80, n.5, p.1079-1082, 1987. 
SAXENA, R.C.; ZHANG, Z.T.; BONCODIN,E.M. Neem oil affects courtship signals and bahavior of brown planthopper Nilaparvata lugens (Stal) (Hom. Delphacidae) females. Journal of Applied Entomology, v.116, p.127-132, 1993.

SCHUSTER, D.J.; MUELLER, T.F.; KRING, J.B.; PRICE, J.F. Relationship of the sweetpotato whitefly with a silverleaf disorder of squash. Hortscience, v.25, p.1618-1620, 1990.

SHARAF, N.; BATTA, Y. Effect of some factors on the relationship between the whitefly Bemisia tabaci Genn. (Homopt., Aleyrodidae) and the parasitoid Eretmocerus mundus Mercept (Hymenopt., Aphelinidae). Zeitschrift für Angewandte Entomologie, v.99, p.267-276, 1985.

SIMMONS, A. Nymphal survival and movement of crawlers of Bemisia argentifolii (Homoptera: Aleyrodidae) on leaf surfaces of selected vegetables. Environmental Entomologist, v.28, n.2, p.212-216, 1999.

SIMMONDS, M.S.J.; STEVENSON, P.C.; PORTER, E.A.; VEITCH, N.C. Insect antifeeding activity of three new tetranortriterpenoids from Trichilia pallida. Journal of Natural Products, v.64, p.1117-1120, 2001.

SINGH, R.P.; DEVAKUMAR, C.; DHINGRA, S. Activity of neem (Azadirachta indica A. Juss) seed kernel extracts against the mustard aphid, Lipaphis erysimi. Phytoparasitica, v.16, n.3, p.225-230, 1988.

SKINNER, R.H. Leaf temperature effects on Bemisia argentifolii (Homoptera: Aleyrodidae) oviposition. Environmental Entomology, v.25, n.6, p.13711375, 1996a. 
SKINNER, R.H. Response of Bemisia argentifolii (Homoptera:Aleyrodidae) to water and nutrient stressed cotton. Environmental Entomology, v.25, n.2, p.401-406, 1996b.

SOUZA, A.P.; VENDRAMIM, J.D. Atividade ovicida de extratos aquosos de meliáceas sobre a mosca-branca Bemisia tabaci (Gennadius, 1889) biótipo B em tomateiro. Scientia Agricola, v.57, n.3, p.403-406, 2000a.

SOUZA, A.P.; VENDRAMIM, J.D. Efeito de extratos aquosos de meliáceas sobre Bemisia tabaci biótipo B em tomateiro. Bragantia, v.59, n.2, p.173$179,2000 \mathrm{~b}$.

SOUZA, A.P.; VENDRAMIM, J.D. Atividade inseticida de extratos aquosos de meliáceas sobre a mosca-branca Bemisia tabaci (Genn.) Biótipo B (Hemiptera: Aleyrodidae). Neotropical Entomology, v. 30, n.1, p.133-137, 2001.

STANSLY, P.A.; LIU, T. Activity of some biorational insecticides on siverleaf whitefly. Proceedings of the Florida State for Horticultural Society, v.107, p.167-171, 1994.

SUMMERS, C.G.; NEWTON Júnior, A.S.; ESTRADA, D. Intraplant and interplant movement of Bemisia argentifolii (Homoptera: Aleyrodidae) crawlers. Environmental Entomology, v.25, n.6, p.1360-1364, 1996.

SYLVESTER, E.S. Circulative and propagative virus transmission by aphids. Annual Review of Entomology, v.25, p.257-286, 1980. 
THOMAZINI, A.P.B.W.; VENDRAMIM, J.D. ; LOPES, M.T.R. Extratos aquosos de Trichilia pallida e a traça-do-tomateiro. Scientia Agricola, v. 57, n.1, p.13-17, 2000.

TORRECILLAS, S.M. ; VENDRAMIM, J.D. Extrato aquoso de ramos de Trichilia pallida e o desenvolvimento de Spodoptera frugiperda em genótipos de milho. Scientia Agricola, v.58, n.1, p.27-31, 2001.

TSAI, J.H.; WANG, K. Development and reproduction of Bemisia argentifolii (Homoptera: Aleyrodidae) on five host plants. Environmental Entomology, v.25, n.4, p.810-816, 1996.

VAN LENTEREN, J.C.; NOLDUS, L.P.J.J. Whitefly-plant relationships: behavioural and ecological aspects. In: GERLING, D. (Ed.). Whitefies: their bionomics, pest status and management. Andover:Intercept, 1990. cap.3, p.47-89.

VÁZQUEZ, L.L.; JIMÉNEZ, R.; IGLESIA, M. DE LA; MATEO, A.; BORGES, M. Plantas hospederas de Bemisia tabaci (Homoptera: Aleyrodidae) en Cuba. Revista de Biologia Tropical, v.45, n.1, p.143-148, 1997.

VENDRAMIM, J.D. Uso de plantas inseticidas no controle de pragas. In: CICLO DE PALESTRAS SOBRE AGRICULTURA ORGÂNICA,2., Campinas, 1997. Campinas: Fundação Cargill, 1997. p.64-69.

VENDRAMIM, J.D.; SCAMPINI, P.J. Efeito do extrato aquoso de Melia azedarach L. sobre o desenvolvimento de Spodoptera frugiperda (J.E. Smith) em dois genótipos de milho. Revista de Agricultura, v.72, n.2, p.159-170, 1997. 
VENDRAMIM, J.D.; TORRECILLAS,S.M. Efecto de extractos aquosos de Trichilia pallida (Meliaceae) y genotipos resistentes de maiz sobre Spodoptera frugiperda (J.E. Smith). In: SIMPOSIO INTERNACIONAL SOBRE SUBSTANCIAS VEGETALES Y MINERALES EN EL COMBATE DE PLAGAS, 1., Acapulco, 1998. Memorias. Puebla: Colégio de Postgraduados, 1998. p.133-144.

VERKERK, R.H.J.; NEUGEBAUER, K.R.; ELLIS, P.R.; WRIGHT, D.J. Aphids on cabbage: tritrophic and selevtive insecticide interactions. Bulletin of Entomological Research, v.88, p.343-349, 1998.

VICENTE, M.; NORONHA, A.; COLAMARINO, E. Modo de ação de um inibidor de vírus fitopatogênicos extraído das folhas de Chenopodium amaranticolor Coste \& Reyn. Arquivos do Instituto Biológico, v.44, p.229-234, 1977.

VILLAS BÔAS, G.L.; FRANÇA, F.H.; ÁVILA, A.C.; BEZERRA, I.C. Manejo integrado da mosca-branca Bemisia argentifolii. Brasília: Embrapa, CNP Hortaliças, 1997. 12p. (Embrapa. CNP Hortaliças. Circular Técnica, 9).

WAGNER, T.L. Temperature-dependent development, mortality, and adult size of sweetpotato whitefly biotype B (Homoptera: Aleyrodidae) on cotton. Environmental Entomology, v.24, n.5, p.1179-1188, 1995.

WALKER, G.P.; GORDH, G. The occurrence of apical labial sensila in the Aleyrodidae and evidence for a contact chemosensory function. Entomologia Experimentalis et Applicata, v.51, p.215-222, 1989. 
WALKER, G.P.; PERRING, T.M. Feeding and oviposition behavior of whiteflies (Homoptera: Aleyrodidae) interpreted from AC electronic feeding monitor waveforms. Annals of the Entomological Society of America, v.87, n.3, p.363-374, 1994.

WANG, K.; TSAI, J.H. Temperature effect on development and reproduction of silverleaf whitefly (Homoptera: Aleyrodidae). Annals of the Entomological Society of America, v.89, n.3, p.375-384, 1996.

WEINTRAUB, P.G.; HOROWITZ, A.R. Systemic effects of a neem insecticide on Liriomyza huidobrensis larvae. Phytoparasitica, v.25, n.4, p.283-289, 1997.

WEST, A.J.; MORDUE(LUNTZ), A.J. The influence of azadirachtin on the feeding behaviour of cereal aphids and slugs. Entomologia Experimentalis et Applicata, v.62, p.75-79, 1992.

WEWETZER, A. Callus cultures of Azadirachta indica and their potencial for the production of azadirachtin. Phytoparasitica, v.26, p.47-52, 1998.

WOLCOTT, G.N. Inherent natural resistance of woods to the attack of the West Indian drywood termite, Cryptotermes brevis Walker. Journal of Agriculture of the University of Puerto Rico, v.41, p.259-311, 1957.

WOOL, D.; CALVERT, L.; CONSTANTINO, L.M.; BELLOTTI, A.C.; GERLING, D. Differentiation of Bemisia tabaci (Genn.) (Homoptera: Aleyrodidae) populations in Colombia. Journal of Applied Entomology, v.117, p.122134, 1994. 
XIE, Y.S.; ISMAN, M.B.; GUNNING, P.; MACKINNON, S.; ARNASON, J.T.; TAYLOR, D.R.; SÁNCHEZ, P.; HASBUN, C.; TOWERS, G.H.N. Biological activity of extracts of Trichilia species and the limonoid hirtin against lepidopteran larvae. Biochemical Systematics and Ecology, v.22, n.2, p.129-136, 1994.

YEE, W.L.; TOSCANO, N.C. Ovipositional preference and development of Bemisia argentifolii (Homoptera: Aleyrodidae) in relation to alfafa. Journal of Economic Entomology, v.89, n.4, p.870-876, 1996.

YOKOMI, R.K.; HOELMER, K.A.; OSBORNE, L.S. Relationships between the sweetpotato whitefly and the squash silverleaf disorder. Phytopathology, v.80, p.895-900, 1990.

ZUCCHI, R.A.; SILVEIRA NETO, S.; NAKANO, O. Guia de identificação de pragas agrícolas. Piracicaba: FEALQ, 1993. 139p. 